\title{
Paul W. Abrahams Interview: October 15, 16, and 17, 2007 Deerfield, MA
}

\section{Session 1, Tape 1, Side A}

NORBERG: October 15, 2007. I'm in the home of Dr. Paul W. Abrahams in Deerfield, Massachusetts, for an interview concerning his career in computing and also to discuss his years as an officer in the Association for Computing Machinery.

ABRAHAMS: Where is David [Brandin] these days, by the way?

NORBERG: He's in Los Altos. They have a lovely home, I would say, in Los Altos, which is off the beaten path, in a sense. It's a very nice house. California houses being what they are, it's a very nice house. And he's still doing some consulting and he's still running around doing other things. He's written a novel, by the way.

ABRAHAMS: Great!

NORBERG: It might be out this month, but if not, it'll be out very soon. He was, what I would say, his normal self. [Laughs]

ABRAHAMS: We had an interesting bit of common experience. We both had prostate trouble at the same time [laughs], so he was telling me all about his adventures with urologists.

NORBERG: Yes, I had those too. I never had any prostate cancer, but I had another form of cancer. The chemotherapy produced some additional problems five or six years later.

Okay. Can we begin?

ABRAHAMS: Absolutely.

NORBERG: As I pointed out to you when you asked me about background and so on, I have a few pieces of information that I was able to glean in various places, like Who's Who in America. But I'd just sort of like to get a general image of your early life and your parents and what they did, both what they did on their own and what they did for you, if there was anything like that. And also to see whether there are any siblings. I haven't heard of any.

| ABRAHAMS: I have three- - two brothers and one sister. I'm the oldest.

NORBERG: Oh, okay. Can we start, then, at the beginning? Not high school. Let's go earlier than high school. Tell me what life was like in your house and in elementary school.

ABRAHAMS: I was born in Brooklyn. You probably knew that. My family moved out to the Long Island suburbs, first Lawrence and then Woodmere, I guess when I was about four or five. 
Actually, it was before then. They moved to Lawrence before I even knew they were moving, and then up to Woodmere, which is a few miles away.

My father was in the laundry business. My mother did not have a college degree, but she got one. I guess she got it when I was about eight or nine years old in psychology. So she was fairly ambitious that way. Economically, they were I would say upper-middle class. My father's business was pretty stressful. It was really my grandfather's business, and in 1943 he died and left a great mess behind him. There were great fights in the family over it, in particular between my father and uncle on one side and the two sisters on the other side. So that was pretty stressful for him, and that went on for a number of years. Then they finally straightened that out. He stayed in the laundry business for, I don't know, till I was probably in my 20s. When he retired, he and my mother went off to Israel.

I'm not sure how relevant this is to anything, but my religious history is in itself I think kind of interesting, because I was brought up in a not orthodox, but I would say a devout, conservative family. I was very devoted to religion as a kid, and even when I went to high school. Then I went to MIT, my theology turned around 180 degrees. I was still quite attached to Judaism for a while, but my beliefs started to change. It was definitely a result of encountering physics and realizing that I just could not put together the notion of a miraculous god with the laws of physics; it just didn't fit. So I first became kind of a cultural Jew for a while. I thought of myself as a deist. Then I said, "Well, what's the difference between a deist and an atheist?" Actually, Thomas Jefferson thought there was a great difference, but I never understood why he thought there was a great difference. So the fact that I changed my religious views so completely (this was late college, early grad school) got my father quite upset. He never quite got over it. He kept trying to convert me back.

But anyway, getting back to my early years, I went to public schools from, I guess, kindergarten up to the fourth grade. Then I switched over to a Jewish school. Not a yeshiva, you know one of the modern Jewish schools, which are now called the Brandeis School, but I guess it was called the Jewish Center School or something like that. That was in Woodmere. At the same time, I also skipped a grade. As a child, I was quite tall for my age, which probably affected me socially in a lot of ways. I was also very shy, physically awkward, which kind of made me more into a geeky type at a time when geeky types were particularly unpopular. So socially, I had a very difficult time with it from my early years. I guess probably that tended to sharpen my intellect in a lot of ways.

The community, as I said, was a suburban community. The area I lived in then was almost entirely Jewish, but there were lots of other areas nearby that weren't at all, so there were a number of different ethnicities around there. The education I got at the Brandeis School, I think that got me started on a couple of things. It probably shaped my politics, that I'm quite liberal. That was certainly the push there. You catch a kid at seven and you get him for the rest of your life, that kind of thing. So that turned me into a political liberal.

That's when I started to get interested in writing. And writing has actually been a major influence on my career and a major part of it, the fact that I could write well, and not just technical stuff. It's kind of interesting to hear Dave Brandin is writing a novel because he also is a very good writer. I've never written novels. When I went to MIT, I wrote a humor column for the MIT newspaper, The Tech.

I guess already I've skipped over grade school a little bit.

NORBERG: What sort of influence did your mother and father have on you in terms of your studies, even in elementary school? 
ABRAHAMS: Not much. My father had a college degree. I guess in his own way, he was fairly intellectual. He also loved classical music. And even though I didn't get to like it until I was in college, it became a passion of mine afterwards. If you look at all these CDs I have, including the complete Bach cantatas, you can tell I'm a person who really likes classical music. I think that was my father's influence. And the other thing was, I was very good at piano for a while. I took piano lessons from when I was six to when I was eight and got to be pretty good at it. I also got involved in a certain amount of composition. I was really, really good at harmonies and things like that.

So I think the complete picture was of a socially awkward, but very intellectualized kid. And in fact, my parents kind of discouraged me from going to MIT, but they didn't stop me. They thought I should somehow be in a more well-rounded place. It turned out that the decision to go to MIT was absolutely right for me. I was very, very pleased with how that worked out. I felt it was just the place I should be.

NORBERG: Let's go back to high school, though. You sort of ran across that. What sort of programs were you part of? Did you go to, say, Brooklyn — whatever the name of the science school is?

ABRAHAMS: Lawrence High School was your typical good but not spectacularly good suburban high school. Actually, I graduated third in my class there. The first and second people were really brilliant. The first was Jean Turoff; I don't know what became of her. And then Martin Cohn, who was a buddy of mine, was second, and he went off to do math at Harvard. I did have some very bright friends at that point. The school itself, there really wasn't a lot of advanced extracurricular stuff.

One thing I remember - and this was when I was in about the seventh grade-I really liked math. And I was looking in the World Book Encyclopedia, and I discovered an article on simultaneous equations. I somehow got fascinated by equations in three unknowns, you know, integers. I kept pestering people to make up sets of equations for me to solve. I loved doing that.

NORBERG: So there was a fairly sophisticated math and science program at this high school?

ABRAHAMS: No, I learned that on my own. High school didn't help me with that. I guess eventually it did. You know, I learned about that kind of stuff later on in high school. About the most advanced course I can remember there was solid geometry. So it wasn't really bad, but there was nothing really special about the courses there. They didn't have any really advanced courses. I was a very good student.

NORBERG: That's clear from the third place.

ABRAHAMS: Yes. Oddly enough, one of the accomplishments I was proudest of at that time was getting a perfect score in the Latin Regents. I also did it in math. Although I remember one math Regents test where there were kind of the multiple choice ones and short answer ones. And then there was a place at the second section of the test where there were some longer questions. You chose three out of four, or something like that. I remember that there were two of them. There was one where you had to do a logarithm thing, which was very, very straightforward. 
And then there was another one that was harder, actually, and involved a lot more thinking. I chose the harder one, not because I was looking for the challenge, but because I was terrified that I would make a careless mistake in the logarithm one. Well, it ended up I ran out of time and didn't get that one at all; I just totally flubbed that. So instead of getting 100 on that Regents, I got a 90. It certainly didn't do terrible things to my grade average, but it does say something about how I thought at that point.

In high school I was in the Science Club and that kind of thing, the Math Club. But I didn't really get a lot of stimulation from the school itself. I did reading, but again, not that much reading. I was smart, but probably not all that intellectual at that point.

NORBERG: Were there any friends there that you might have had interaction with over the rest of your life? Some part of it, anyway?

ABRAHAMS: Yes. There was one was I think of, Robert Colman. Actually, he had a somewhat parallel career to mine in a different field. I met him in a summer camp. I haven't seen him for a few years, but we've more or less stayed in touch over the years. He went to Harvard when I went to MIT. I don't remember exactly what he majored in, but he then went into medicine. At the same time, I was pursuing math and computer science. Right now, he's a professor, I guess of hematology at Temple University Medical School. Brilliant guy, one of the world's leading hematologists. I see him now and then, but I haven't seen him for about three or four years. The occasion for seeing him was itself kind of interesting. One of the hobbies I picked up was wild mushrooms. I had a girl friend that was down in Delaware at one point, and we went looking around there and we found morel mushrooms, which are not so easily found. Every spring, I had an expedition down to Wilmington to look for morels. I've still been doing that. Bob and his wife Bobbi lived right near there, so I would always get together with them for dinner when I went back to look for my mushrooms.

NORBERG: That's an interesting connection.

ABRAHAMS: Yes. Let's see if there was anything else I noted here. Oh, maybe this is too boastful, but at least when I was about nine or ten, I had a spectacularly high IQ. At least, it was measured as spectacularly high- 180 . Now, I have a feeling in retrospect that partly I was precocious, so I think it's faded somewhat. But that was one of the reasons I got advanced by a grade. I even remember an experience I had at the Jewish Center School. As you would expect at a school like that, one of the subjects was Hebrew. I didn't know any Hebrew. So I went into this class, and I was totally lost. But I wasn't terrified. And the teacher asked me, "Are you doing okay?" And I said, "I'll get there," or something like that. Anyway, I started getting like zeros and tens on the tests, and then the tens and the zeros turned into thirties and forties. The thirties and forties turned into seventies and eighties. After about, I think it was even less than a year, I was really just about at the top of the class in Hebrew. So it was definitely the right thing to do to persist in that.

NORBERG: You indicate on your list here that your first interest in computers was with the IBM Selectric.

ABRAHAMS: The Selectric Sequence Electronic Calculator. That was one of the things that impressed people at that age, kind of interesting. I don't remember why it was that I went into 
Manhattan, but I was there. And I happened to go by the IBM building at the corner of $57^{\text {th }}$ Street and Madison. In the window, they had this view of this huge computer. Physically, it was very impressive. It made great clanking noises. It had wide rolls of paper on which it was printing out moon orbits. Even though I didn't really understand at that point what it was all about, I was very impressed. I said, "I want to learn more about these things."

NORBERG: How old were you? Do you remember?

ABRAHAMS: Yes. At that point, I was about 14 or 15, I guess. I couldn't have been much older than that, because I went to MIT when I was 16. Just because of when my birthday is, I was a little bit ahead anyway. Skipping a grade got me into MIT at 16, which is kind of young. Actually, a lot of my friends were Catholics going to parochial school when I was in the lower grades. But I didn't really have too much touch with-I guess I did, actually, have some contact with them even after that, even when they were right near me, were neighbors.

NORBERG: Did you ever get to play with the Selectric Sequence Calculator?

ABRAHAMS: No. It was just something to look at, at that point.

NORBERG: Did you know that MIT was doing some things in computing before you went there?

ABRAHAMS: I think I did, but I'm not sure. I remember the thing that attracted me to MIT was it was the best place for math and science. So that was what really meant a lot to me. I don't know if you want to start up my MIT part now.

NORBERG: Let's go ahead.

ABRAHAMS: Okay. I may think of some other things related to the earlier things. Oh, one thing I should mention about my earlier times is, when I was in high school I was going to a summer camp also. I actually wrote a kind of operetta. So I was writing lyrics and things like that. I was really doing a lot of writing and I just loved doing it. This was all creative writing; non-technical. One of the things I believed - and still believe - is that creative writing helps technical writing. A lot of it is in common. The ability to write good creative stuff also helps to write good...

NORBERG: You were using the Gilbert and Sullivan music and supplying your own lyrics.

ABRAHAMS: Exactly. I wrote this operetta of sorts called "The Pirates of Wall Street." And actually, it almost got staged at one of my local high schools. I don't remember exactly why it never came off, but it came very close. Not the high school I was at, but I guess it was a music teacher at one of the other nearby high schools who heard about this and got interested.

NORBERG: When it came time to get finished with high school and go on to some sort of university training, did you think about MIT only, or were there other institutions who had a similar math and science program that interested you too? 
ABRAHAMS: I had the usual safety schools or other possibilities. I didn't get into Harvard. I have a feeling even if I had, I still would have chosen MIT. With MIT, I knew it was where I wanted to go. It was just, the other things were reasonable second choices, but not what I wanted. Or not what I preferred, is the best way to describe it.

NORBERG: On the Upper Dean's List for six semesters, and then a big slump.

ABRAHAMS: Right. [Laughs] It was like I panicked. That's what I would guess happened. I don't remember that too well. But even at MIT, I was really excelling. Though I think I became much less exceptional after that. Whether everybody else caught up to me or whether I just dropped back, I don't know. But fortunately I didn't drop back so far that I couldn't still have a pretty good career.

I knew I wanted to learn about computing, but at that time, there really wasn't much computing to learn about at MIT.

NORBERG: Anywhere.

ABRAHAMS: Anywhere. So it was my junior year when I first took a computing course. I remember the first one I took was one with Charles Adams. That gave about equal emphasis to digital computing and analog computing. That's where things were in those days. Then I took another course - and maybe it was a couple of them-from Dean Arden. I wrote my Bachelor's thesis on linear programming. I also was doing work-maybe it was part of the course. I don't remember. But I did get to work on Whirlwind, which was another one of these physically spectacular computers. Computers look much less impressive now!

NORBERG: Before we go into too heavily on computing, what other courses were you taking as well?

ABRAHAMS: I was taking, I guess, kind of the standard things. Mostly math. I mean, I took about as many math electives as I could. I also took music courses, though I didn't play an instrument. I don't know, did I mention I played the piano a lot when I was a kid?

NORBERG: You mentioned that you had taken lessons from six to eight. I assume that was years.

ABRAHAMS: Yes. But I didn't keep that up. But that's when I really got involved in classical music, at that stage. I was living in one of the dorms, and they had a cable. The students set up this cable that ran around the dorms. It had 12 conductors - I still remember that. And there were people who'd broadcast music over this thing. If you had an amplifier, you could pick up these music broadcasts, or you could do your own. So I did some of both. I'd mostly listen to other things, and I did some of my own. I guess it was at that point that I also actually built myself an amplifier. In those days, kids did that.

NORBERG: I want to talk about the overall program at MIT that you were involved in. So there was music, there was mathematics.

ABRAHAMS: And creative writing. 
NORBERG: Oh, that's good. Okay, creative writing. And you mentioned physics.

ABRAHAMS: Yes. Well, physics, everybody had to do physics.

NORBERG: Who was teaching physics at MIT?

ABRAHAMS: Hans Mueller, of the Mueller-Geiger Counter. And also Bruno Rossi. I remember the first course I took, I think, was optics, and then mechanics. I guess I did electricity. Oh, I also minored in electrical engineering, which intrigued me. So I learned a lot about that.

NORBERG: Did you take any courses in electricity and magnetism?

ABRAHAMS: Yes. That was part of it.

NORBERG: What sort of texts did you use? Do you remember?

ABRAHAMS: The only one I remember was Gilliman's Circuit Theory. Let's see. What else?

NORBERG: That sounds like enough to me, actually.

ABRAHAMS: Yes. I didn't have a terribly unusual program, as I can remember. I may think of something later on.

NORBERG: You indicate here on the notes you just passed to me that Dean Arden was your thesis advisor.

ABRAHAMS: That's right.

NORBERG: This is for the Bachelor's degree in mathematics?

ABRAHAMS: Right. Yes. I did note down the thing that was interesting. When I wrote my Bachelor's thesis, I did it on a Flexowriter and printed it all on paper tape. But of course, paper tape isn't the easiest thing in the world to correct. So I kept patching paper tapes. It was probably ultimately not such an easy way to do it. And the other thing was, I remember printing out - when I was over at--Whirlwind - some kind of a banner for the girlfriend I had at the time. Frank Verzuh, who was one of the staff people there got really annoyed when he saw what I was | doing, [Laughs] But he was kind of a sourpuss anyway, had that reputation.

NORBERG: How did you come to center on linear programming as a thesis topic?

ABRAHAMS: I think somebody suggested it to me; I don't remember who.

NORBERG: There was a lot of interest in linear programming at that time. 
ABRAHAMS: Yes. I don't remember how I got into that, though. It wasn't something I really pursued afterwards, either.

NORBERG: Working on Whirlwind. I assume that's Whirlwind I.

ABRAHAMS: That's right. Yes. Nothing else really comes to mind, except that that was when I really got involved in computers.

NORBERG: Now, were you at MIT continuously from '56 to '62?

ABRAHAMS: Yes. I guess it was '62 when I left and went down to New York. I hadn't yet actually gotten the degree, but I was very close. Then I took a job down in New Jersey.

NORBERG: That was with the international...?

ABRAHAMS: ITT, International Electric Company. They were the ones who actually printed up my thesis for me, which was very nice of them.

NORBERG: Let me go back to the mathematics department, though. What were the strengths in that department? What was the faculty like, and where did they come from?

ABRAHAMS: I remember a couple of people, but I don't remember too well what the strengths were. In fact at that point, I probably couldn't have appreciated it. I must mention a few of the professors I remember. Dirk Struick, who specialized in differential geometry, was notable because he got in trouble with the House Un-American Activities at that time. And MIT at that time wasn't too supportive of people who got into trouble because of their political beliefs.

NORBERG: And he wrote a very important book on the history of mathematics, too.

ABRAHAMS: I didn't know that. I don't remember whether he actually got fired or not. That was a time when MIT did fire people like that. It would never happen now. They really wised up to protecting themselves against political interference. But at that point, I don't think quite got the idea because they weren't used to it yet. Also, I guess I vaguely remember John Nash, of course, who became very famous with Beautiful Mind. I remember the department head, Ted Martin. I don't remember what his specialty was, but he was really a friendly guy. He had a very thick Texas accent. I remember that too. I think I took my first calculus course with him. I also did some advanced placement. So as I remember, I never actually took second-year calculus. I just advanced, took the test and got through it. Maybe there were a couple of things I did that way. So I moved on into more advanced math courses relatively early in my math career.

NORBERG: Who, then, were you most affiliated with, as you were going through your doctorate?

ABRAHAMS: Marvin Minsky and John McCarthy.

NORBERG: They were not both in the math department, were they? 
ABRAHAMS: I think originally they were. And then McCarthy switched over to EE. But the two of them were working together. The fact that they were in different departments didn't really matter very much. Because once I really got into computing, my connection with the math department was really mostly a formality. I would have been in computer science, I'm sure, if they had had it then. So it was all very ad hoc.

That was also around that time that MIT acquired the IBM 704. Those were also the days, of course, everything was done with batch processing. It was not easy to get computer time, either. So people basically were running their own jobs, but they were overseen by the manager of machine operations, Mike Salomita who got the nickname Mike the Mighty Momo. [Laughs]

NORBERG: What's this association you had with Minsky and McCarthy?

ABRAHAMS: I think in my first year in grad school that someone in the math department told me that Minsky was coming over from Harvard and I should meet him. We got along very well. $\mathrm{He}$ is one of the more unusual people in the world, in more ways than one.

NORBERG: I interviewed him, by the way.

ABRAHAMS: Oh, so then you know! [Chuckles] He has a really mischievous sense of humor. He looks at things in ways that nobody else ever looks at them. At that time, there was a kind of cluster of people in this field. I remember Minsky, McCarthy, Ray Solomonoff, and Oliver Selfridge. They had parties fairly often, and the grad students who were involved in this got invited to the parties. So it was all kind of a very friendly collection of people. That was also the time when these professors started buying big houses in Brookline, which I guess at that time could be gotten fairly cheaply. A couple of them were living in mansions. I imagine they were making decent salaries, but not huge. But mansions I guess at that time could be gotten in Brookline for very little money because nobody wanted them. Who was the other one I met?

NORBERG: Bob Fano was there at that time.

ABRAHAMS: Oh, yes. I knew him then, but not well. Someone was working with Norbert Weiner and did cybernetics-type stuff. Corbie (Fernando Corbato) was also around.

NORBERG: Well, it will come to you. So we can go back to those parties. Does that thought give you any insight into who was there? Who were there as graduate students?

ABRAHAMS: Oh, yes. I remember the other graduate students. I remember a number of them. And then there was the artificial intelligence project that I got involved in at that point.

NORBERG: At what point?

ABRAHAMS: I guess it was about my third year of grad school or something like that.

NORBERG: So it was '59 or something? 
ABRAHAMS: Yes, some time around then. I'm still trying to remember the name of the man who- he was quite famous, and he worked with neural stuff too, but it wasn't Rosenbloom.

NORBERG: McCullough?

ABRAHAMS: Yes, Warren McCullough.

NORBERG: He was there at the time working on those problems.

ABRAHAMS: And I also met Claude Shannon and was working with him and McCarthy-on a chess program. It calculated two-move mates and was written in FORTRAN. That was also the time that FORTRAN was starting to hit the world.

NORBERG: Students.

ABRAHAMS: Yes, students. Danny Bobrow, Tom Evans. Who else? Jim Slagle.

NORBERG: Jim and I were colleagues at Minnesota for a while.

ABRAHAMS: That was when he started to go blind, by the way. When I first met him, he could see but just barely. He used to make notes on huge pieces of paper. Then he wasn't even able to do that anymore. Those are the ones that occur to me right off, but I may--

NORBERG: So this was not a big group, then, that were talking about or who were interested in computing problems?

ABRAHAMS: It was not a big group? No it wasn't. At least in that aspect of computing. There were other things going on in computing, too, at that time. Computing started at MIT just around the time I entered grad school, I think. Although even when I left, they still didn't have a computer science department. But the focus was switching from math to EE. There was certainly a lot of intellectual ferment going on at that time.

NORBERG: Especially at MIT.

ABRAHAMS: Yes. Another person I remember who was in that circle that didn't have an | academic appointment was Rollo Silver. I don't know if that name ever came up.

NORBERG: No. Can I get some timing straight here? You got your Bachelor's degree in '56.

ABRAHAMS: Right.

NORBERG: Did you go immediately into graduate school?

ABRAHAMS: Yes I did. And I went down to New York about '62 and actually got the degree in '63.

NORBERG: Okay. You did a dissertation on machine verification of mathematical proofs. 
ABRAHAMS: That's right. And I still remember what Minsky said to me when he read it, which is, "I never knew you could write," which I felt very complimented by. In order to understand it, you really needed to know both mathematical logic and LISP, and I actually wrote two tutorial appendices in it, one on mathematical logic and one on LISP.

NORBERG: What was the principal aim of your dissertation work?

ABRAHAMS: Well, it was to determine - and I think, actually, it was McCarthy's idea — was it possible to mechanically verify mathematical proofs, to run them through calculations, a computational process, and see if they were right or not. Well, I didn't get terribly far with it, frankly, because I think the technology wasn't there. The computing facilities were, at that time, so primitive that everything was like slogging through molasses. So basically I wrote LISP programs to check the proofs of, I guess it was Russell and Whitehead's Principia Mathematica. What was interesting was what I learned before I even put the proofs into the computer was that their reasoning in many cases was remarkably sloppy in mathematical terms, which came as a surprise to me. And I think it came as a surprise to a lot of other people too, because they just kind of took certain things for granted that were true, but not proven. And to this day, I'm not sure exactly - now that computers can do so much more-I'm still not sure how far it's possible to get in mechanically checking mathematical proofs. Because there are a lot of things that mathematicians do that are not entirely mechanical, but they kind of pass them off because they're so obvious. Like a lot of the inductive processes. This is like, "If we do this over and over again until we get there," basically. It seems perfectly obvious when you look at it, but in fact, the formal justifications for it just aren't there, and I don't know that anybody ever quite figured them out. So it was interesting for me to discover how sloppy some of that stuff was. To me, the interesting field to examine — and I looked at it but I didn't really do any checking — was linear algebra, because that had a lot of these repetitive processes or proofs in it. Do this until it converges. It seemed perfectly obvious. Where is the justification for it?

NORBERG: Was there any reaction to the dissertation once it appeared, among mathematicians or among some of your special colleagues within computer science?

ABRAHAMS: Not much, I don't think. Basically, I think the feeling — which I have to admit was true-was I had worked on a hard problem. I had gotten as far as it was possible to get at that time, but I hadn't solved it.

NORBERG: Because I read some citations, one particularly by Zinn in which he indicated that the mechanism was too difficult to use. Therefore, he at least saw not much value. I don't have the citation here with me, but he wrote this paper about the proving mechanism in this early time of computing, and illustrated that it was, he didn't use the word flawed, but it's not going to work very effectively. He's the only one that had a negative thing to say about it. But others who commented on it, there are a number of citations.

ABRAHAMS: You probably know more about them that I do. I remember one of the interesting things that I looked at was what happens when you're proving something and you make use of the fact that two plus three equals five. How do you know that? How do you prove it? Do you have to go back to the very foundations of integer arithmetic to prove it?. 
NORBERG: That's what I would do, but I don't know whether that's the most appropriate way.

ABRAHAMS: Yes, but you do these things all the time. To prove each one, it would be an enormous and probably useless effort. I think the answer, in retrospect, is that you try to prove that a certain computer program is correct, namely, the one that does arithmetic. Then you can actually run the program. I know that this has been a controversial issue in mathematics.

Generally, there are things that you can only prove by running them through computers, as far as people know.

NORBERG: Its the same thing in physics.

ABRAHAMS: Yes. And I think the whole notion that that was a way to prove things only arose when the possibility was there of proving them that way.

NORBERG: Did any of your student colleagues use the techniques that you have described? I don't mean a list of techniques, because that's somewhat different. But Slagle was doing something on Student — he called the program Student — and it was about algebra, I think.

ABRAHAMS: I think so; that sort of sounds familiar. I think that the biggest thing that actually I got out of all of that was probably my involvement in LISP and becoming really very knowledgeable about that and putting that to use later on.

NORBERG: Was that a general interest in the artificial intelligence group?

ABRAHAMS: Oh yes, oh yes.

NORBERG: Most of the people there did indeed use LISP in various programs that they began to work on, like Bobrow.

ABRAHAMS: And there was a lot of interest in Newell and Simon's work.

NORBERG: Mm-hmm [yes], which I was interested in it too.

ABRAHAMS: I remember the feeling that artificial intelligence was just around the corner.

NORBERG: It's still just around the corner. [Laughs]

ABRAHAMS: That's right! I guess it was a few years later that I understood—or I think I understood - what was really going on. The analogy I drew about artificial intelligence was that a group of very clever people had decided to build a tower to the moon. And every year, they announced with great fanfare that they've added 20 stories to this tower, and look how high it is! But the moon still isn't much closer.

NORBERG: [Laughs] You've spent a lot of time writing about LISP. LISP, LISP 1.5, sequence programs and so on. 
ABRAHAMS: Sequence predications. That was with Information International, which was one of my post-grad school jobs.

NORBERG: So then at MIT you were just doing straight LISP?

ABRAHAMS: Pretty much.

NORBERG: I recollect that Information International put out a number of these as technical reports. Is that right?

ABRAHAMS: Yeah, I guess they had some kind of a contract.

\section{Session 1, Tape 1, Side B}

ABRAHAMS: I was quite involved with LISP, starting with grad school. I did my thesis in it. I worked on the LISP project and the implementation of it. My specialty at that time was the input/output. So I devised the input-output system.

I actually ended up working more closely with McCarthy than Minsky; McCarthy was the one who suggested my thesis topic. So it was his idea. And he also wrote this very influential paper around that time, "Recursive Functions of Symbolic Expressions." I remember he asked me to look at the same problem, and I didn't get that far with it at that point. But then he really had his own approach in mind. So he just took the problem back, basically.

The artificial intelligence project at that time was housed in Building 26, which was the building where the IBM 704 was. And there was kind of a large bullpen room where the grad students hung out. Then there was a door going into the office where Minsky and McCarthy were. They would kind of emerge from meetings like royalty through this door. [Laughter]

NORBERG: Well, I have here in front of me an article which is entitled "LISP II: Programming Language and Systems."

ABRAHAMS: Oh, yes!

NORBERG: And there are a number of people on this from Information International and also from System Development Corporation.

ABRAHAMS: Yes, yes, yes. That was later on, so I wanted to talk a little bit more about what I can remember about grad school. A lot of it is just interesting anecdotes that are probably not particularly historical significant perhaps.

NORBERG: We don't know that.

ABRAHAMS: There was a big file cabinet in that office. I still remember, the top drawer was labeled History, the middle drawer was labeled Mystery, and the bottom drawer was labeled Ballast, because you didn't also open it when the other ones were open, the cabinet would fall over. [Laughter] 
NORBERG: [Laughs] That's funny.

ABRAHAMS: I thought that was great.

NORBERG: It says here you played Go with McCarthy.

ABRAHAMS: Yes, I did. And you can see I have a Go set right there. McCarthy was the one who got me interested in Go. He was much, much better than I was.

NORBERG: It's a very difficult game.

ABRAHAMS: It is, it is.

NORBERG: I don't play it. But I tried once and I didn't get very far.

You want to continue with graduate school.

ABRAHAMS: Yes. I guess the main thing I think of is that was the point at which I really got into computing rather than mathematics. I started out with the idea that basically I would take all these math courses. But that didn't happen. And I also took some fairly advanced electrical engineering courses, some of which frankly I got very confused by.

NORBERG: When did the AI lab get set up then?

ABRAHAMS: Probably about '58 or '59. I remember Fano was involved with that. I remember Corbato was running the computing center at that point.

NORBERG: A little early for that, but it's around then.

ABRAHAMS: It was around then, yes. And what else did I think of at that...?

NORBERG: Who was sponsoring this within the administrative structure at MIT?

ABRAHAMS: It was in the engineering-- Or was it? I think Jerry Wiesner, who later became president of MIT, was very involved in it at that point. I may have the chronology wrong. I know at one point he was.

NORBERG: There was a radio lab for electronics or something.

ABRAHAMS: Yes.

NORBERG: It seemed to be the umbrella office that looked over...

ABRAHAMS: The research, right, yes. And I think that was Wiesner's outfit, if I remember right. But I could-- You know, again, long time ago.

NORBERG: He had moved up from that. I think Fano was there when you were there, was he not? 
ABRAHAMS: Fano was involved, but I don't remember who did what at that point.

NORBERG: Okay. Now, you note on the paper you handed me that there was a setup of the AI Lab in Building 26. What does that mean?

ABRAHAMS: Yes. Well, let's see, what did I say? Building 26 was...

NORBERG: I don't care about the room number; that doesn't matter. I want to know what your role was in this.

ABRAHAMS: Yes. Well, I was just one of the peons, basically. I wrote LISP code. There were a couple of other people who were not on the academic staff who were very influential. Steve Russell, who was really one of the whiz programmers. Michael Levin, who also turned out to be a second cousin of mine, I discovered. And they basically were the staff who did a lot of the LISP stuff, just getting things working.

NORBERG: What else was going on in the AI Lab at the time, besides LISP?

ABRAHAMS: I don't remember. [Laughs] That I don't remember. Maybe I'll think of something.

NORBERG: I was told once about a thing called Minsky's Claw, which was an attempt to develop an AI system where you could program this claw to do certain kinds of jobs, taking an egg and holding it, for example. That sort of thing.

ABRAHAMS: I don't remember that.

NORBERG: That could have been later.

ABRAHAMS: I think it was.

NORBERG: Winston told me about that.

ABRAHAMS: I do remember this canonical problem that McCarthy talked about and had us working on, which he called "Want-At-Airport." Basically, how do you get to the airport? And having an artificial intelligence program that could figure that out we went through all kinds of analyses about how such a program might work.

NORBERG: But it never did.

ABRAHAMS: It never did. I guess I mentioned Shannon and the two-move mate chess program.

NORBERG: That's here. That is early for Fortran. I used Fortran on a Master's thesis in physics. I tried to develop a theoretical proof for the adsorption of gases on a simple surface. And I remember it was very easy to do in Fortran. This would be 1961. 
All right. Let's move on to International.

ABRAHAMS: Information International. Oh, and also I was at ITT for about a year and a half. At that point, I decided I wanted to live in New York, and so I got the ITT job. They were actually located in Paramus, New Jersey, so I would commute in every day from lower Manhattan. I was living at $30^{\text {th }}$ Street and $1^{\text {st }}$ Avenue, right across the street from the Bellevue psychiatric wards. Sometimes at night I could hear the screams. It was about a 35-minute drive to work, as I remember. It was about that time, I think, that they put the lower deck on the George Washington Bridge, which made things easier.

I thought I would do artificial intelligence there, but I didn't really do an awful lot of that. I remember fairly early on, I was-I don't remember the name of the department I was in. I remember the man who ran it. I guess he was at that time a little bit of a father figure for me, Jacques Harlow. They got a request for a proposal for something called Quantitative Methods of Information Processing System of Evaluation. I think it was for the Air Force.

NORBERG: It says here Navy.

ABRAHAMS: Maybe it was the Navy. But anyway, there was a buddy of mine who was working there, Michael Lipp. I looked at it, he looked at it, we both said the same thing, "You can't do that." But Jacques said, "Well, write a proposal anyway." So I wrote a proposal. We got the contract and I felt like I had been shot in the head. [Laughs] How do you do something when you just said you can't do it? So we kind of fudged and fiddled and came up with something. It wasn't very good. We knew it wouldn't be very good because they asked us to do something we couldn't do.

NORBERG: Is ITT the International Telephone-Telegraph?

ABRAHAMS: It is. I don't remember at what point they acquired International Electric Company, whether that happened before I got there or what. It became a division of ITT. So I spent a lot of time working on the QMIPSE project. Then they also got this contract programming job, which I got assigned to, to straighten out some statistical programs at the United Nations. So I got assigned to that. And actually, I worked on that quite a bit. I have an odd memory of that. When I was assigned there, they gave me this marvelous office that belonged to some functionary there who was on leave or whatever, overlooking the East River. Beautiful view, right across to Long Island. And it turned out that it had an odd disadvantage. I | learned things about the UN, physically about it, at that time. Directly across from it was a Long Island Railroad barge terminal, so they would load these barges with the freight cars and send them down the river with tugboats. Someone told me that every once in a while, one of the freight cars rolled off the barge and into the river. So I couldn't stop looking at the barges, waiting for that to happen! [Laughter] But I never saw it happen.

NORBERG: Sounds plausible, though.

ABRAHAMS: Yes. And it was very conveniently located because I was living actually on East $30^{\text {th }}$ Street. It was just like a 10-minute walk up from my apartment on East $30^{\text {th }}$ Street up to the United Nations. And another thing I learned-which few people realized who weren't working there-was that the air in the building was really bad in the Secretariat Building. The reason was 
that they had two utility floors where they had the air intakes. I think it was the $60^{\text {th }}$ and $32^{\text {nd }}$ or something like that. And about six blocks south of there was a big Con-Edison plant with a smokestack. The typical airflow out of the smokestack took the smoke directly into the air intakes of the Secretariat Building. Somebody wasn't thinking clearly when they designed it.

NORBERG: Yes. Okay, now I learned that you were a section supervisor from '62-'64.

ABRAHAMS: That's right. And I don't remember the name of the section. I basically got promoted. I don't think that I did all that much supervising.

NORBERG: Section Supervisor ITT Data Information Systems.

ABRAHAMS: That's right. I think that was what the International Electric Company got renamed to. So I remember the QMIPSS project and I remember the UN project. And I think there was one other I got involved in, which I can't think of anymore. But I realized that things were really getting kind of uninteresting. I could have stayed. But I didn't really want to.

NORBERG: But you stayed at least until '67.

ABRAHAMS: Yes. Was it that long?

NORBERG: That's what I learned, but I don't know whether that was true or not.

ABRAHAMS: I thought I was there about a year and a half. Maybe it was two years. But then I went to Information International. I'm trying to remember when I went to NYU.

NORBERG: 1967.

ABRAHAMS: Okay. That's right. So there was the time in between when I went to Information International, which was run by Ed Fredkin, whom I had known from my grad school days. In fact, Ed started it up in the same building where DEC did in Maynard, Mass. He knew all the DEC people. Brilliant guy. Very imaginative guy. He didn't even have a place to live when he was doing that, so he ended up living in the apartment-actually half of a twofamily house - that I was living in with my roommates in grad school. So I got to know him then. Basically, we gave him a place to stay.

NORBERG: How big was Information International?

ABRAHAMS: Well, it started like about maybe 20 people, maybe even less, and then it got bought out. Ed is still a very imaginative guy, one of the most imaginative people I've ever met in this field. His gig at that point was programmable film readers, which he was selling to petroleum companies. But he also got involved and was very interested in LISP. That's when the sequence prediction stuff happened. He had a contract-I don't remember with whom - to do that. That was also where the LISP II stuff happened, at Information International.

So the switch may not be clear from all of this, but the switch from ITT to Information International happened probably in around ' 65 or ' 66 , something like that. They were located in Boston, but I didn't want to go to Boston, actually Cambridge. Ed wanted me to work for him, 
so we agreed that I would become his New York office. So I became the New York office on East $23^{\text {rd }}$ Street. I got involved - they were also one of the very early timesharing kinds of things, because we actually had a phone connection out to Santa Monica. So I did a lot of work. I don't remember exactly what the machine was; it was one of these transmitting typewriter-type things.

Which reminded me of something else that was kind of interesting? I don't know where this fits exactly, but at one point in grad school, the people in this circle got very interested in typewriters, in particular the old IBM Selectrics. You could buy them real cheap. So I got one of those and I ended up doing that. No, that's right, I did my dissertation on that, a Model 1 Selectric. There were a whole bunch of other people in that group who also had Model 1 Selectrics. Of course, Selectrics of any variety are ancient now.

NORBERG: The connection between $\mathrm{I}^{3}$, I'll call it, and System Development Corporation came about how?

ABRAHAMS: Basically, Ed got a contract...I don't remember whether it was with SDC or with the government working with SDC.

NORBERG: The footnote here in the LISP II programming paper, it says that it was an Air Force contract with the Electronics Systems Division at Air Force Systems Command. And in performance of an ARPA order, 7733 AR.

ABRAHAMS: What I don't remember was whether the contract went to SDC alone and then SDC brought in Information International, or whether it was to both of them. That's what I don't remember. But I do remember that I spent a lot of time out in Santa Monica. I even had an apartment out there for a while. I was very deeply involved in the LISP II project. Another person who was, I guess-- Michael Levin was also involved in it. He had been involved with the effort back at MIT, too. And also, Jeff Barnett was...

NORBERG: The names are there, if you want to look at that.

ABRAHAMS: Ah, oh yes. Clark Weissman, Lowell Hawkinson, I remember them. Clark Weissman, I remember. He was an interesting guy. He was a guitarist with Pete Seeger or someone like that in the folk music community. He had this other musical career, although it didn't continue. Then he ended up, I don't remember what he did, but he got very well known for it. The story behind this was that there was a feeling basically LISP had to be upgraded. And of course, the Air Force was very interested in seeing this happen. At that time, LISP II looked like a pretty advanced language in a number of ways. We wrote a paper for the FJCC, or maybe it was the SJCC, and I was the primary author even though I wasn't the primary technical person, although I certainly was one of the technical people. But nobody was up to writing a paper. I was the one who stepped into the breach and wrote the paper. That's another case where my ability to write was very, very useful.

NORBERG: Did you know about Fredkin's association with System Development Corporation as an outside consultant? 
ABRAHAMS: I don't remember. I knew that he was working with them on this. I don't remember how this came about, but I guess he was an obvious center of LISP expertise at that point.

NORBERG: Because SDC had this six-million-dollar contract with the Air Force, and that's when they got the FSQ-7 or something like that, the Q-32.

ABRAHAMS: Yes. Right. Oh, I remember that computer.

NORBERG: The group out there were not really doing very much, and Licklider was getting rather upset. So he got Fredkin to go out and hold a seminar out there and see what these people were doing and what the prognosis was about the programmers that would hold the program contract itself. Fredkin, according to Licklider anyway, managed to put them on a different track which was more acceptable to Licklider and his associates at ARPA.

ABRAHAMS: Yes. I have completely forgotten about Licklider, but I knew him too back in my MIT days, you know, my grad school days. You reminded me of something else. I had also worked, done some part-time work over at BBN at that time on the PDP-1, which I had forgotten about till this came up. I guess he was, at that time, at BBN. Bolt Beranek and Newman. I don't know if their name has come up much.

NORBERG: Oh, yes. We looked into their work very thoroughly. Where were people like Bob Everett, and you mentioned Forrester? They were the people on Whirlwind I and Whirlwind II.

ABRAHAMS: They were above my level. So I guess I knew the names. I never actually got to talk to them.

NORBERG: How would you evaluate your time at Information International? In terms of career prospects, in terms of what you had been doing in graduate school, what you hoped to do when you were finished and had gotten your degree.

ABRAHAMS: I was pretty pleased at that point. It turned out to lead to other things. It was my work with I guess the sequence prediction stuff that led me to write a paper that was presented at a conference on algebraic manipulation down in Washington, which in turn was what led to the NYU connection.

NORBERG: Okay. Can we hold that one for a bit? I want to go back to a paper that John McCarthy wrote on the history of LISP. He did this for the first History of Programming Languages Conference that ACM ran and so on. But on page 219 of this piece, he mentions a whole array of people who helped with the development of LISP, but he talks specifically about simplifications of LISP. He mentions the paper, "Recursive Functions of Symbolic Expression," and then "Computations by Machine." That was his paper, I take it?

ABRAHAMS: Oh, yes. 
NORBERG: Now, while you were going through this exercise with him, and I want to show you the list of people that were acknowledged by him as people who were responsible for LISP. It's LISP that I'm really interested in.

ABRAHAMS: 1 , or 1.5 .

NORBERG: Well, LISP and 1.5 are two different versions, I think.

ABRAHAMS: Well, 1.5 was actually the one that got implemented, really. LISP was just a collection of Fortran subroutines, as I remember, initially.

NORBERG: I thought he was very generous in his comments about that was responsible, what part he played. But was Fredkin and his group interested in LISP in itself, or were they trying to do something else with it?

ABRAHAMS: I think they were interested in LISP itself. How that came about, I don't quite remember. All these people knew each other and probably had a lot to do with it. I mean, they were just personally friendly.

NORBERG: What about the association with Project MAC?

ABRAHAMS: I don't remember much about that. I remember that it was there.

NORBERG: But that, as you know, involved Licklider and Fano on a rather fundamental level, because it seemed as if when Licklider published "The Man-Machine Symbiosis", that that became the program of ARPA in 1963.

ABRAHAMS: I remember that paper. You've read it, I guess? What struck me about it was not so much its technical content as its literary quality.

NORBERG: Okay. And what struck me was the visionary quality of the paper because of all the things that he suggested as research topics that one could move on to.

ABRAHAMS: Is he still alive?

NORBERG: No. He died in 1995 [actually in 1990] from some complications of an asthma attack. He got to the hospital reasonably on time, but he was just too far gone. They couldn't do anything about it.

ABRAHAMS: I certainly knew him, but I didn't know him well. I remember that paper struck me as visionary, but it was one of the most, in the literary sense, eloquent papers I ever read.

NORBERG: Eloquent. That would be the right word. It certainly was.

ABRAHAMS: It read like a fairy tale. 
NORBERG: But he pulled it off, got the government to buy it. Here's the list of people. "Many people participated in the initial development of LISP," and so on. "I can remember Paul Abrahams, Robert Brady, Dan Edwards, Patrick Fisher, Phyllis Fox, Saul Goldberg, Timothy Hart, Louis Hodes, Michael Levin, Leibold, David Luckham, Kim Maling, Marvin Minsky, Daniel Pollack, Nathaniel Rochester, and Steve Russell." Now, would you say that that is a fair assessment of the colleagues that he had when LISP was being developed?

ABRAHAMS: He mentioned Steve Russell, right?

NORBERG: Yes, he did. That was the last name.

ABRAHAMS: I can't offhand think of anybody else who was involved. I know what became of some of these people. But I've lost touch. I was at Dave Luckham's wedding, I remember, but that was a long time ago. And I was also quite friendly with David Park, who sadly died young; about age 50, I think it was. He was English. In fact, I still remember visiting him and his wife in England at one point. I don't know if you're interested in knowing what became of these people. I can tell you some of them, not all of them.

NORBERG: If they were involved in your life, yes.

ABRAHAMS: Although at the point when they went off to do other things they weren't involved in my life anymore. I believe Michael Levin went off and became involved in some kind of hippie community, something like that. I think; I'm not sure about that. I seem to remember hearing that. Let's see. Who else?

NORBERG: Because he worked for a while at System Development Corporation in Santa Monica.

ABRAHAMS: Yes, I think it was after that. Bob Brayton went to IBM. Dave Luckham became a professor somewhere or other, but I don't remember where. What were some of the other names again? Some I just lost total track of. Tom Evans and Tim Hart are still in the Boston area. I exchange Christmas cards with Tom Evans. He started some kind of a computing company in Lexington, I believe, which is where he's living now. I heard Bob Brayton, I remember he went to IBM and is working there. Dan Edwards, I don't remember what became of him. Patrick Fisher, I think he went to Vanderbilt University, if I remember right. I could be way off on that. Phyllis Fox, I don't know. Saul Goldberg, I don't know. Tim Hart, as I mentioned, is in the Boston area. Lou Hodes I don't know. Michael Levin. David Luckham, I heard of him, but again, not recently; I don't remember what he was doing now. Minsky, of course, you know about him. Nat Rochester, I don't know whatever came of him.

NORBERG: He stayed at IBM for a long time. He was an IBM Fellow for a while. You made an interesting connection there by saying that when you were working on these problems at Information International, at ITT, that the connection with NYU came up.

ABRAHAMS: Yes. Well, basically the way that happened was that Max Goldstein, who was running the computing center at NYU, came to the conference where I gave the paper on sequence prediction. Basically he was hunting for staff, so he recruited me at that point. The 
other thing that was going on with Information International was, it was around that time, or it was a little earlier than that, that Ed sold the company to a group headed by a man named $\mathrm{Al}$ Fenaughty. I don't know if that name ever came up.

NORBERG: Yes. It's come up in other circles.

ABRAHAMS: Yes. And anyway, the whole character of the company changed. It became much more corporate. And also, they decided they didn't want to have a New York office anymore, so if I was going to stay I'd have to move to California, which I didn't want to do. So I was ripe for the picking at that point. Max made me an offer over at NYU, so I went there. Initially it was not a faculty appointment, though eventually it became one. It was a staff appointment. I did teach. At that time, NYU actually had two campuses. They had an uptown campus in University Heights in the Bronx. Then they also had the downtown campus. So I taught a course up at University Heights for a while, which is kind of a devilish place to get to, it turned out. So for a few years, I was on the staff of the Computing Center at NYU.

NORBERG: Which was the AEC Computing Center?

ABRAHAMS: Yes, that's right. They had the Control Data 6600 there, which at that time was a very spectacular machine. I think they had the model, one of the first couple that was built. And one of the indications of that was the wires were kind of hanging out from the mainframe because they couldn't squeeze them all in. I remember how impressed I was by that machine. It still astounds me to think that in my pocket, I carry much more memory than that machine had, and it cost me $\$ 25$.

NORBERG: What sort of problems were being worked on at the AEC Computing Center?

ABRAHAMS: Lots of hydrodynamics. Partial differential equations were the specialty of the place. So basically anything that used partial differential equations. There was one professor who I think made quite a fortune in consulting, Paul Garabedian, who did consulting for aircraft companies. Another person I remember who was very involved in Monte Carlo stuff, I was quite friendly with Malvin Kalos. It was an interesting kind of relationship between computer science and math there because the mathematicians had their own concept of what computer science was, and it was basically numerical computing. This other stuff, they didn't really-I mean, they considered it somehow a little bit infra-dig or something. But at the same time, they began to realize that that's where a lot of the money was. There was always a bit of tension between math and computer science.

So I went there, I think it was in '67. I was on the staff for a couple of years. And I don't remember at which point it was that I was certainly interested in LISP. I got dragged into various Jack Schwartz projects.

NORBERG: Tell me about Jack Schwartz.

ABRAHAMS: Jack Schwartz is a brilliant guy. Very determined. And frankly, I think he tended to exploit people some. He was always looking for new recruits to work on his projects. And it wasn't generally all that rewarding. But I remember one of the projects that I was involved with was this early timesharing system called Sharer. I was the one who managed to 
crack one of the real debugging problems with it. It was a very interesting story. I still remember this. The system worked with teletypes in a few offices. The system would work for maybe 15-20 minutes, something like that, and then it would crash. They noticed this happened a number of times. Then I vaguely noticed something seemed a little bit odd, which was it seemed - but I wasn't at all sure of this; it was very hard to be sure - that when the system wasn't used quite as heavily, it seemed to last a little longer. I thought about that. I said, "Well, if that's really what's going on, the extreme case is to put the thing up and don't let anybody use it. See how long it lasts." And it did. And it crashed in about two minutes. It turned out, once we discovered that, then we were really on the way to tracking it down.

The explanation of it was fascinating. The whole thing had been written in Fortran. One of the questions, one of the things that the system program did was to ask, "Is there any input?" And if there wasn't any input, it would get an end of file signal. It turned out that in the Fortran runtime library routines, there was a counter of how many ends of file it had seen. When the counter hit $2^{15}$, it would overflow onto the next digit, and as a result, the thing would crash.

NORBERG: Interesting. Were they doing any contracts for ARPA at the time?

ABRAHAMS: I don't think so. I don't remember any.

NORBERG: I don't either, but I wanted to confirm that. Now, you were there, what did you say, two or three years in the Center?

ABRAHAMS: I was in the same place; it was just that my title shifted. I was there from ' 67 to '80. And of course, the later part of that was when my ACM career began too, which we'll get to pretty soon. There were some interesting things that happened there. I started to get very interested in PL/I at that point. I was interested in compilers, and PL/I was the most humongous programming language around except possibly Algol 68. So I decided that I was going to write a compiler for a CDC-6600 for PL/I, since if I could compile PL/I, I could compile anything. That was really quite an undertaking. The method I used was to bootstrap it from the existing compiler on the IBM 360. So I kept bringing tapes back and forth from the 360. It was in the next building over, so I kept carrying tapes back and forth between the two buildings until I finally got the compiler to the point where it could compile itself. I had to kind of tweak it a little bit to get it to do that, but I could get it to do that. I still remember I was up all night getting it to work, and the next day I brought in a bottle of champagne. The first time that I could run the compiler without having to use a 360 anymore.

NORBERG: I'll come back to that in a few minutes, because it seems to me, when you became a member of the American National Standards Committee X3J1 that there was an attempt to develop a standard for PL/I.

ABRAHAMS: Oh, yes.

NORBERG: Again, I'll put that off for a moment. What I'd like to ask you, because it's not very often that we get a person like you before the tape recorder to talk about the standards system, how it worked. So I'd like to ask you first, how did you come to be involved in the ANSI group? 1968. 
ABRAHAMS: I'm trying to remember how it started. It definitely started with PL/I. Let's see, I'm trying to remember how I first got on to that committee. I think there may have been some kind of a call for volunteers or something like that. Once I got involved, I got very involved. I remember that much about it. I also got a grant so that I could go to the meetings, which tended to be in very nice places like Carmel, California. [Laughs] I still remember a lot of them at the La Playa Hotel there. It was a very congenial group. It may have even been through somebody at IBM that I learned about this. I don't remember. I remember going to the meetings, and I remember a lot about how they ran.

NORBERG: Would you tell me about that?

ABRAHAMS: Yes. There was a Technical Committee, and IBM was very influential in it as you would expect, because they were the ones who devised PL/I. But there was also the competing effort of the Multics group. So both, of course, were represented there, plus a number of other companies, and a few freelancers like me. I guess I can't think of what they did before they got the document from IBM. The F compiler manual was the basis of the standard, except that IBM basically gave it to them with some fixes. Then the way that the committee proceeded was to write proposals. People would put in their proposals to make various changes, some of which were huge, like a whole chapter. Then these would get voted on. At some point, I guess they planned to actually produce an official ANSII document, because they were an ANSI committee.

I don't remember at what point it happened, but then IBM got very interested in formal definitions. They had a group in Vienna that was working on a formal definition of PL/I. They decided that's what they wanted to push. So they proposed basically replacing the F compiler manual with this formal definition that described an abstract PL/I machine. For quite a while I was a true believer, and then I became somewhat of a skeptic of this approach, having seen what happened when people actually tried to use it. One of the problems was that when you write these elaborate formal definitions, how do you know that they really say what you want them to say? Whatever they say, they say it precisely, but it may not be the right thing. So there were problems of intent. And then another thing was that people somehow forgot that just because you write a formal definition doesn't mean it's free of bugs. They had a lot of bugsprogramming bugs, operations that operated on undefined input and that kind of thing. A very interesting story about that. I was Chair of one of the subcommittees. I don't remember exactly which one. But I ended up hosting a meeting at NYU in 1967. I think it was '67.

Maybe it was later. But I remember what was going on then. That was the time of the Vietnam War, and it was the time of the student protests. I had this meeting at the Courant Institute and the meeting was interrupted by the protests. I don't remember how we got word of it, but we had to vacate the building immediately.

\section{Session 1, Tape 2, Side A}

ABRAHAMS: So we moved the meeting over to my apartment. I remember there was a whole delegation of people from IBM Vienna who were at this meeting too, because they were the ones who had done this form of definition, the original one. The students actually made quite a mess of the building, including lots of graffiti. And I still remember my proposal, that somebody else suggested that maybe we should add our own graffiti, you know, the people in the building, and 
the thing was, "All Power to the Exponents." [Laughs] And I decided that, in fact, we could even take that a little further with, "The Root of Power is Unity." [Laughs] Which I loved because it actually makes both political and mathematical sense.

NORBERG: Yes, but did they understand? I saw an interesting comment from Bernie Galler, who, when the students came into his classroom-he was teaching 200 students in a programming class - and they started chanting from the back and wouldn't allow him to speak. So he walked up to the blackboard and he printed, "Hitler 1933." That took the steam right out of the demonstration and they left. Anyway, that's just an aside.

ABRAHAMS: Well, we didn't have classes for a while. And they also tried to blow up the computer. They actually had a fuse running to it. But the fuse died out, so the computer survived with a certain amount of minor damage.

NORBERG: Getting back to PL/I.

ABRAHAMS: Yes. So it was that stage when I got interested in PL/I, I got interested in the Standards Committee. I was just very, very much involved in this whole PL/I world, which was interesting because of course I wasn't working for IBM at that point. I don't remember if I noted down anything about that period that I haven't mentioned.

NORBERG: I'm curious as to how you got to doing the compiler for PL/I.

ABRAHAMS: It just seemed like the natural thing to do. It seemed like an interesting challenge since I was interested in the language and I was interested in compilers. I guess I thought, "Gee. That's really something worth doing." Not many people would-- You know, it was just like a mountain to be climbed at that point. The compiler actually did get distributed to a number of places. It wasn't a complete implementation. And to get it to a complete implementation would have been a huge effort.

At one point, Control Data actually gave me a grant to work on this. I still remember that it was '75-'76 when I took my sabbatical, which has also all kinds of stories associated with it. I was living not far from here in Hadley, Massachusetts. I was friendly with people over at the University of Massachusetts, but no official connection. I remember some people came all the way from Minneapolis to meet with me there to talk about this compiler. They were working on one of their own, but I don't remember whatever happened to it.

NORBERG: I was going to ask you if you always replaced another one that was already in existence.

ABRAHAMS: It wasn't already in existence. It reminds me, especially you'd appreciate this, being from Minneapolis, that another thing that happened, going back earlier when I was at MIT, I had a series of summer jobs. The first one was at the Freed Transformer Company in Brooklyn, basically drawing up performance curves on transformers. The second summer job was in Minneapolis, working for the company that Seymour Cray worked for before he founded Cray, Electronic Research Associates. I spent the summer programming stuff for the ERA 1103, which later was named the Univac 1103. The summer after that I worked for a company on Long Island, American Bosch Arma. I don't think they still exist. (I was living with my parents during 
the summer, again, in Woodmere.) They had a contract to write a simulator for an airborne computer that was supposed to run on that same type of computer I had worked with a year before, the ERA 1103. This one was located at Wright Patterson Air Force Base in Dayton, Ohio. I was just supposed to be an assistant on the project, but it quickly transpired that I knew far more about the 1103 than anybody else there. That's how I kind of became in charge of the project in face if not in name, even though I was just a college student. I kept running out to Dayton even when I was back at MIT, and I got a little bit of a consulting gig to work on this thing.

NORBERG: Were you trying to make a connection with PL/I?

ABRAHAMS: No. There wasn't one. I'm trying to remember what was it that I was thinking of when I thought of that story.

NORBERG: If I remember correctly, you were talking about using the 1103 to develop a program, and I thought it was PL/I.

ABRAHAMS: No, it wasn't. PL/I wasn't even around at that point. PL/I didn't appear until I guess the late ' $60 \mathrm{~s}$, I think it was. It came out, I think, soon after the IBM 360 came out. I don't remember exactly the time frame.

NORBERG: Which one? It came before the IBM?

ABRAHAMS: PL/I, I think, came shortly after IBM introduced the 360.

NORBERG: Okay, so 1964.

ABRAHAMS: Sometime around there. The descriptions of it really intrigued me. I remember George Radin was very eloquent about how this is a language where you can do anything, the idea of merging COBOL and Fortran plus other things. And the criticism of PL/I was that it was much too big. Years later, I decided that that was not exactly the right criticism. The problem in a way was that it was too small. They had left out some very important things, in particular the ability to make general data type definitions just wasn't there. People did it with the LIKE attribute, which was really kludgy and ended up just introducing all kinds of complications.

NORBERG: I read somewhere (and I don't have the papers with me now) that the IBM developments and using them as a standard seems to have given rise to resistance by others. Whether that was university others or corporate others, I don't know.

ABRAHAMS: You mean using PL/I as a standard?

NORBERG: This was before unbundling, certainly.

ABRAHAMS: Yes. I remember people were unhappy with PL/I, but it seemed to be more technical than commercial doubts. One of the things I might mention about the PL/I Standards Committee was that I didn't fully appreciate at the time some of the commercial angles that 
underlay some of the technical arguments. People were saying that it should be this way rather than that way, and the real reason is that's how their compiler worked.

NORBERG: "Their" being IBM?

ABRAHAMS: Not just IBM. IBM was not the only player at that table, although IBM did that, too. But the biggest problem of the formal definition was that it was probably extremely difficult to understand. I taught a course on it at NYU called "An Exegesis of Standard PL/I." I explained to people, "An exegesis is a $\$ 10$ word, but the $\$ 20$ word is hermeneutics, which is the study of exegesis." [Laughs]

NORBERG: So just to complete that thought, you were teaching that to your students there. Were other languages being taught, too?

ABRAHAMS: Oh, yes. I was teaching a number of different courses. I was teaching undergraduate courses on operating systems, graduate courses in...I forget what it was exactly. I don't remember the name of the field, other than it had to do with formal properties of languages. It's been a long since I've thought about that stuff.

NORBERG: Symbol-manipulation languages?

ABRAHAMS: That was something else. This was the real mathematical end of it, the stuff that came down from Chomsky, basically. Different classes, automata theory and things like that. That kind of stuff.

NORBERG: Which was going on at MIT while you were a graduate student.

ABRAHAMS: A little of it. I don't remember really getting involved in it, but then that was all the theoretical area. I remember two people that wrote papers that had a reputation of being almost impossible to read, Ginsburg and Rose. Ginsburg, Rose, and Greibach. One of the things I did while at NYU was to spend most of a year in the Soviet Union. Jack Schwartz, you know, he loved to arrange odd things, and he arranged the trip for me. I taught a course at Moscow State University on LISP. Actually I taught two classes: one was on the LISP language, and the other was on compilers. I had a translator for the first one. The second one, the students basically had to know English to be there.

And that was also the year I learned Algol 68. I still remember that story, because I had a lot of time on my hands, and I had an Algol 68 definition. That also had the reputation of being extremely difficult to understand. So I just worked and worked and worked on it, and eventually I did understand it, except for one or two things. And I actually met a Russian who was also involved in Algol 68 and I asked him about the things I couldn't understand, and it turned out that there were just a couple of errors in it. Another person I worked with at NYU was also involved in Algol 68, which was Robert Dewar. I guess his name comes up now and then.

NORBERG: One of the names you mentioned here as working with, Andre Yershov.

ABRAHAMS: Yes. He was a buddy of Jack Schwartz, and that's how I got this visit to Novosibirsk. I don't remember exactly what I did in Novosibirsk except that I was working 
there at the Computing Center. That was in the summer, and that was great because it's not a place you'd want to be in winter.

NORBERG: Moscow's bad enough. It sounds like not in the summer either, with all the mosquitoes. Forget insect repellent; you should have brought nets.

ABRAHAMS: No, no nets. I remember that it rained a lot. There was a fairly long walk from the hotel I was staying at over to the laboratory, and it went on these paths through the woods, which were beautiful. But oh, I remember carrying an umbrella, and the mosquitoes all clustering under the umbrella. It was kind of funny in a way. That was a very interesting year. I don't remember that I made any contact there outside from friends that really had any influence on my career. It was just an interesting thing to do, basically, to spend a year there. And to learn Algol 68- that was probably the thing that affected me more than anything else, professionally.

One other thing I wanted to mention about that Algol 68 business, was that when I told Robert Dewar a couple of years later that I had done this, which I had learned Algol 68 from the manual, he said, "Well, you'll never learn the revised Algol 68 from the manual." [Laughs]

NORBERG: Okay. We'll come back to Deerfield later on. I want to pick that up in the third phase. When did you first become associated with ACM? When did you join as a member? What did you do there after you joined? And so on?

ABRAHAMS: Well, I became a student member, I think, in my grad school days. I just basically read the Communications and that was it. I had nothing. I had no role in the

| organization at all. The way I became associated was... I don't remember if it was the PL/L Standards Committee or something, but a couple of people in SIGPLAN got to know me. Maybe it was because of one of the conferences that I was at, at that point.

NORBERG: Were you at the conference in '67 on operating systems? I don't remember now.

ABRAHAMS: I don't remember either. I'm sure since you've done lots of these interviews, I'm sure it happens that people in later phases think of things they had done in the early phases.

NORBERG: Absolutely. Frequently.

ABRAHAMS: Anyway, to answer your question, somebody-I don't remember who the initial contact was, but someone asked me to run for Vice Chair of SIGPLAN. What I didn't know, because I didn't know how these things worked, was that I was the shadow candidate. They had really somebody else in mind. [Laughs] But this was the beginning of one of the reasons I was so successful in ACM. I was very good at writing campaign statements, extremely good at it.

NORBERG: Okay, so your first association was with SIGPLAN?

ABRAHAMS: That's right. I became Vice Chairman. And once I was Vice Chairman, actually it was fairly natural at the next election to step up to Chairman. And I was pretty active as Chairman. I was still at NYU at that point when I was SIGPLAN Chair. I did a couple of things that I was really happy about. One of them was I recognized there was a problem that the main SIGPLAN Conference was "Principles in Programming Languages." It was a joint conference 
between SIGPLAN and SIGACT - the automata theory people - and pretty much run by the theoreticians. There was really not a lot of pragmatic stuff in it. So I realized I wasn't going to change it, so the thing to do was to start another SIGPLAN Conference, which I think, if I remember right, was the conference on compiler construction. So I got the second conference going, and it turned out it's been very successful ever since.

And the other thing I did as SIGPLAN Chairman, which hearkens back to my other stuff earlier with LISP and everything, was the conference in Portland, Oregon, on symbol manipulation, which I think was joint with SIGOA, the office automation group, as I remember. But that conference got a lot of attention because it had some very good papers in it. So that was one of the things I did as SIGPLAN Chairman. There were those two conferences. The compiler construction one was a continuing thing. That one wasn't just one year. The other one, the symbol manipulation, was a one-shot thing.

The other thing that I did that I was very proud of, I also had gotten, I guess, a little bit of a consulting gig on ADA. I don't remember exactly what I was doing, but I did something on it. And the ADA language definition, there were four competing contractors for it who would actually get to write the definition. Then ARPA was going to decide which one got it. I decided that once that decision was made, it was very important and very useful to get the definition to the SIGPLAN membership as quickly as possible. So basically I got all the preparations set in advance - whoever it was, the printers and everything. So once ARPA decided, I think it was only about 48 hours before that issue of SIGPLAN Notices with a definition was in the mail to the membership. The only reason it was so fast was because everything had been set for it in advance. Otherwise it could never have been that fast.

NORBERG: Let's go back to the beginning of this for a moment, if you will. I'd like to know what were your earliest impressions of ACM activities that you were involved in, like SIGPLAN, and then later on as the SIGBoard Chairman.

ABRAHAMS: When I got into this, I really didn't know much about it. All I knew was reading Communications, which seemed like an interesting magazine. And I think I had published a couple of papers there or something. But I didn't really have a very clear picture. Well, once I got involved in SIGPLAN as Vice Chair, I started to see a little of it. Steve Zilles was the chair at that point. He was really very helpful to me. We got along quite well. I haven't seen him for a number of years, but we still exchange Christmas cards. So I started to get a better picture of ACM when I became SIGPLAN Chairman because then I had to deal with things at the higher level. I think it was because I was an activist chairman that I got to run for SIGBoard Chairman. The same thing happened again. I wasn't expected to win, but I wrote a really good campaign statement. [Laughs] That was the motif throughout my whole ACM career. In fact, to jump ahead quite a bit, after I was done with my presidency and everything, subsequently, a number of people asked me to help them with their campaign statements.

NORBERG: Well, in the list that you and I prepared of publications, there are a number of Sigplan Notices starting in 1973, and they seem to be an uncoordinated set, I'll call it. That's not | meant to be pejorative either. One of them was on Snobol_4. Another one was on lookup of structured variables, another was on structured programming, and another was, I assume, a teaching tool, "Realism in Programming Languages."

ABRAHAMS: I don't even remember that one. 
NORBERG: I read it. It was very interesting.

ABRAHAMS: The common thread was an interest in programming languages and what they should be like. That's all I can think of off-hand.

NORBERG: What is the, I don't want to say "association", that's not the right word. But what is the value in writing these technical contributions of two or three pages long in computer science? You probably remember there's such a thing as Physical Review Letters, which would be equivalent, I think - at least analogous - across the two organizations.

ABRAHAMS: Well, I think it was to basically propagate ideas rather than to do research in the more orthodox sense. In fact, I think I could even say that basically I was never really a researcher. I was a programmer. I think at some point-I mean, I was I think a very good programmer. But that's where my heart lay, not in doing research in the normal sense, which might be the reason why my academic career was pretty unspectacular. So my real talents turned out to be almost, I wouldn't say “coincidental," because some weren't like that. But I landed in academia, and I'm not sure what a better place would have been. But writing English and writing programs were really what my strong points were.

NORBERG: Okay. But you didn't answer my question yet. The question was, what was your earliest impression of these meetings of ACM when you began?

ABRAHAMS: Ah. When I started going to meetings, I think I didn't know all that many people. They were kind of interesting, but I don't remember that I was terribly impressed. That's one of the things that I really don't remember much about at all. I'm trying to think back to my SIGPLAN days. Let's see, what else did I write here?... This is to give me some ideas.... I don't remember too much about the SIGPLAN chairmanship, actually.

NORBERG: Except for the conferences that either you attended or organized?

ABRAHAMS: Yes. That was the main thing I remember, getting these conferences organized.

NORBERG: Did you play any other roles besides those two?

ABRAHAMS: No. Not that I can remember.

NORBERG: Okay. So up until the early ' 80 s, you were active more in the special interest groups.

ABRAHAMS: That's right, just in the special interest groups. And then in 1980, I became SIGBoard Chairman, and already I realized that I was on the historic path to the ACM presidency because a number of SIGPLAN Board Chairs had become presidents of ACM.

NORBERG: But your colleagues said to me-not about you, but about the organization, because I asked them was it natural to go from vice president to president to past president - and at least three people have said to me no, there was no natural route there, that it was coincidental, 
more or less, that people were elected or not elected, and it was not expected that when you were elected vice president that you'd go on to be president. As I look at the election results, that seems to be borne out.

ABRAHAMS: I think there was a string of years when the vice presidents did become presidents, and that's kind of what led me to expect that. The SIGBoard Chairman never went on directly to be president. But a lot of SIGBoard Chairs did eventually—like David Brandinbecome president. Peter Denning was another one. Maybe even Jean Sammet. I think that one of the advantages I had in doing both the SIGPLAN thing and the SIGBoard thing was that I hadeven though I've forgotten what it was now-I think I really had a good understanding of how things worked. That made me quite effective in these jobs. I could perceive what problems were and I sometimes could see how to solve them. Sometimes I couldn't, but I had a very realistic sense of the world of these things.

I remember, as SIGBoard chairman, I was also pretty much an activist. I remember, for example, organizing the first long-range planning committee meeting of the SIGBoard, which was a kind of retreat, which we had in, I believe it was San Diego. We spent a lot of time talking about how to make things right. It was a very productive meeting. We didn't get to half the stuff we wanted to, but still, it was a very productive meeting. It was continued after my time. Unfortunately, what had been intended as a contemplative retreat turned into another administrative meeting.

NORBERG: Is that the one where the new charter and organization of the SIGBoard took place? Or was developed, maybe, is a better way to say it.

ABRAHAMS: I think that may have happened after my time.

NORBERG: No, I have the memorandum in front of me here that says on January 24, 1981 that you had submitted to the Executive Committee a new charter and organization for the SIGBoard.

ABRAHAMS: Then I probably did. I must have, but I don't remember anything about it.

NORBERG: Well, I don't have anything to say about it other than that it was done. But there was some little bit of controversy with Peter Denning, who wanted a sentence put in. I'll tell you what it says here: “At Peter Denning's request I've included a sentence in square brackets in the paragraph dealing with the Vice Chairman of the Board, 'I believe that the sentence should be omitted." [Laughs] So for some reason you didn't like it.

ABRAHAMS: I remember having conflicts with Peter Denning, and I mean significant conflicts about my SIGBoard role and the SIGBoard chairmanship.

NORBERG: How did that come about? Because he was president then in 1980-82.

ABRAHAMS: He was president, and I was SIGBoard Chairman. He was trying to force something on the SIGBoard as I remember. I don't remember what it was, but I remember the conflict. I even remember where it came to a climax, which was at a meeting at the Bonaventure Hotel in Los Angeles. I remember that much about it. I don't remember what the issue was though. 
NORBERG: I think the issue was who is naming the office of the vice chairman.

ABRAHAMS: Ah. I've completely forgotten that I had devised a new charter, but it sounds like the kind of thing I would have done at that time.

NORBERG: I put a red mark around it. "The vice Chairman is appointed with the advice and consent of the president." And that made this document different than if that sentence were omitted.

ABRAHAMS: Yes. It was this whole thing about the external control of the SIGBoard. How much autonomy did the SIGBoard have?

NORBERG: Just for completeness about this period, were you serving in any volunteer roles with other professional associations at the same time?

ABRAHAMS: No, just ACM.

NORBERG: Just ACM, okay. All right. We're been going two hours. Do you want a break? [Break]

All right. We're picking up where we left off, and we were talking about your various roles in the early years with ACM. You started to talk a little about Peter Denning.

ABRAHAMS: Yes. I wish I could remember the details of this letter. Peter is a very strongminded guy. And I've actually been fairly friendly with him at times. I don't remember what the conflict was, but I remember it was a real conflict that I had with him, when he was president and I was SIGBoard Chairman, about the powers of the SIGBoard, or maybe it was this issue-- I don't remember what the issue was that you found, but I don't remember why it was significant. But I guess it must have been. Within ACM, there are a lot of power centers. And there are also, I think, some misperceptions about the power centers. In elections, people talk about the interests of the SIGs versus the interest of the chapters. I think for the average member, they don't give a damn. They don't see it that way at all. I have a pretty good understanding of the election process now-I've voted in enough organization elections to understand that people basically are choosing among unknowns and make their choices for very trivial reasons.

NORBERG: Was the SIGBoard Chairmanship the first time you were on the ACM Council?

ABRAHAMS: Yes, it was. So that also gave me an introduction to the Council, so I got to see how that worked. That was when I started to get ambitious to become president, or at least I saw that as coming down the road. The main thing I remember about-- I remember just kind of being very good at organizing things on the SIGBoard. I don't remember exactly what I did, except for that Long-Range Planning Committee. But I do remember the sense that I had run it pretty well. As far as Peter Denning was concerned, I had conflicts with him. I've also worked with him on things. In fact, long after my major ACM career was over, he actually arranged for me to work on an ACM project. He was doing this work on computing as a profession or something like that. He asked me to do some of the grant-writing stuff, proposal, and things like that. That was because he knew I could write that kind of stuff. 
NORBERG: Yes. He was very generous in his remarks, I thought. In fact, he had very few things to say that could be taken as negative.

ABRAHAMS: Oh. Interesting.

NORBERG: Yes, it was to me too, because as I read the materials beforehand and I read the ACM forum and so on, I thought, "Wow! This is going to be..."

ABRAHAMS: I could have told you the name to bring up that would have provoked a reaction. Somebody you probably never heard of mentioned, Hal Lamster.

NORBERG: No, never knew him.

ABRAHAMS: Peter was running, I guess there was a kind of open-question session to the president of ACM, members could come and ask questions. Hal Lamster, I don't remember if he was Chairman of the chapters, but he was very much involved in the chapters. I don't remember exactly what he asked or even how he asked this, but Peter's response was, "You seem to be drunk." [Laughs] And he wasn't.

NORBERG: [Laughs] That's quite insulting. Oh, boy.

ABRAHAMS: [Laughs] That's why I said, if you ever get to talk to Peter, ask him about his encounter with Hal Lamster.

NORBERG: I have already interviewed Peter.

ABRAHAMS: I know you did. So you probably won't get to talk to him--

NORBERG: I don't remember him bringing up that name at all, and that's not a surprise. He probably didn't want to bring up an embarrassing moment. But let me come back to the SIGBoard for just a few more things that I think might be relevant. By taking over the SIGBoard, what did you hope to accomplish?

ABRAHAMS: Basically, I guess I felt that the organization of it or the way it ran was somewhat fossilized, as well as I can remember. I felt it just wasn't working. It wasn't being very effective. I felt that it could do a lot better. And I wish I could remember more about those years. I just remember - now that I have this general impression, but not really much detail to back it up.

NORBERG: Who did you work with then? When you were SIG Board Chairman, who in the various special interest groups did you work with? By group and by name.

ABRAHAMS: Let's see. I remember that there were several different area directors. And the area directors had SIGs underneath them that they basically supervised. I certainly worked with Jack Esbin, I remember that. Jack is a real nice guy, and I get along with him very well. He was the one who lost the election to me, but he didn't seem to be bothered by that at all. I remember 
Mary Van Deusen, who I guess at that point was a SIGPLAN Chair whom I had known.

Actually, she had been at Intermetrics in Cambridge, and I knew her from back in those days. And David Wood, who also eventually became Secretary of ACM when I was president. I'm trying to remember who else I was hanging out with there. I think I had some interaction with Andy van Dam, who was involved with SIGGRAPH.... I trying to remember who else was there.... Ron Oliver was another name that pops up. He was involved with SIGGRAPH. Oh, Jon Meads. Jon was finance advisor. He was quite a character, and a buddy of Dave Brandin, too. I don't know if Dave talked about him at all.

NORBERG: I don't remember the name, no.

ABRAHAMS: He was from Portland. He was involved with SIGGRAPH. And he was a real counterculture type - hard drinker, among other things. SIGBOOZE founder.

NORBERG: How does he become a financial advisor? To whom?

ABRAHAMS: To the SIGBoard, because SIGBoard had a financial advisor, and that was Jon Meads. I think it was when I was chair; I don't remember for sure.

NORBERG: What would this financial advisor be involved in?

ABRAHAMS: Looking at budgets, SIG budgets.

NORBERG: They were that big that it was necessary to do that?

ABRAHAMS: Oh, yes. An awful lot of what I did - what any president or SIGBoard chairman does - is looking at budgets of things. I was really a little surprised to discover how much of the job involved that. When we get to the Presidency, I can talk about some other aspects of the budget stuff. But somehow before you get into this, you think it's an intellectual job. Well, maybe in some sense it is. But so much of what you deal with is really administrative.

NORBERG: But I always thought that in the special interest groups that there would be a sort of taking in and putting out, as opposed to any need for a financial advisor.

ABRAHAMS: Well, every SIG had a budget. They ran conferences and things, and there were the dues level issues, and there were SIGS that weren't making it financially and ultimately got shutdown. Viability. I forgot about that, but there were viability reviews. And in fact, every SIG had to go through that. Some of them it was pretty straightforward, that they were very viable indeed. Some of them it wasn't so obvious that they could survive. There was one on SIGBIO, I think it was, which covered biological applications of computers. SIGBIO was pretty marginal. I don't remember whether they ultimately got shut down or not.

NORBERG: I don't know if they did.

ABRAHAMS: But that was one of the things that the SIGBoard did was to review the viability of every SIG. I think it was annually, or maybe it was biannually. 
NORBERG: I've seen some reports of the various groups that the chairs of the various groups, and they tend to run anywhere from a paragraph to a whole page. Not much more than that. And the same thing for the regional representatives.

Okay, you and I both are interested in this controversy over the SIG overhead memorandum, which took place at the same time that you presented the new charter organization.

ABRAHAMS: Yes. I was involved in that.

NORBERG: So they're all sort of tied in together. Do you remember any of the details about this argument? It goes back a long way to at least July of 1976 when Jean Sammet put in a proposal that she wanted to see them run more effectively, and there ought to be some money retained by the major organization.

ABRAHAMS: Well, I don't remember it terribly well, but my impression looking back on it was the real question was it was hard to find any driving principle except how much money can you extract from the SIGs, basically. [Laughs] Increasingly, the SIGs were where the money was. And who controlled the money. That was a big issue. Was it really the SIGs? In some sense it was clearly ACM, but the SIGs had a kind of moral control over it. There was some kind of a separation in the budget, I don't remember the details of it, that caused the SIGs to be in a different pot. So the SIGs were running a surplus while the rest of ACM was running in deficit. The idea that somehow the SIGs should contribute to the headquarters' costs was perfectly reasonable. The question was, how much? This discussion, I think, went on with every SIG Board chairman as far as I know. I was at a disadvantage because I wasn't really-- I guess I kind of knew the issue would come up, but I wasn't prepared because I didn't know how it would come up or how much pressure there would be, and how to deal with it. At that point, I was relatively new to the job as SIGBoard Chairman, so I just didn't know the headquarters people that well. I mean I knew them, but not that well. And I didn't know what sort of power I really had to fight back. So I gave more than I should have, as I remember.

NORBERG: Did you have any association with Dan McCracken on this?

ABRAHAMS: Not that I can remember. I certainly knew him.

NORBERG: He was president at the time.

ABRAHAMS: Yes.

NORBERG: And then Denning.

ABRAHAMS: I don't remember how the SIGBoard elections overlapped the rest of the ACM elections. I don't think it was at the same time. The SIGBoard Chairman was elected by the SIGs, not by the members. There were a few people on the ACM Council who were not elected by the members. The treasurer was not elected by the members. The SIGBoard chair and the Publications Board chair. The Publications Board was another big power center within ACM, and probably still is. That was run by Stu Lynn, who made himself quite a name in some other connections that I can't quite remember. He was a very, very interesting and very slick guy. 
NORBERG: What do you remember about him other than that?

ABRAHAMS: He was very eloquent, very smart, and he really ran the Publications Board as a kind of fiefdom. A lot of this comes up when we talk about the presidency...

\section{Session 1, Tape 2, Side B}

ABRAHAMS; There were a lot of financial issues related to the Publications Board and to CACM. We'll get to that, I think, when we talk about the presidency, but I'm trying to think about the earlier days of the SIGBoard, and also my role on ACM Council at that point.

NORBERG: You mentioned here in your notes on page two that you remember meeting with John McKegney and Sidney Weinstein, where they were pushing you to give them more money. There is a memorandum of agreement which was agreed to by Aaron Finerman, and you were at the meeting when it was finalized, and so were a couple of other people like Leubitz.

ABRAHAMS: Yes, Joe Leubitz. I remember him.

NORBERG: And, "Beginning in Fiscal Year '82, ACM will charge, and then, i.e., recover from (which I think is an interesting parenthetical statement) the SIGs $50 \%$ of the overhead applicable to them." Apparently you agreed to this.

ABRAHAMS: I agreed to it as long as I didn't know how to fight it. I remember feeling, not too long after that, that I had been had. But I had agreed to it, so I was stuck with it. I agreed to it because I was too green to not agree with it.

NORBERG: But wouldn't there be certain people on the various committees, like the Finance Committee, who would be trying to help you in understanding these issues? Or were they all on the side of the management, I'll call it?

ABRAHAMS: Well, I don't remember where other people within the organization were, but I do remember what happened. The basic outline of the meeting was, it was just the three of us. Basically, I had no real sense of what power I had over the situation. I probably had more power than I realized.

NORBERG: Why would people like Weinstein and McKegney have great authority when they were on the staff? And the staff relationship with the volunteers was quite different than in many other organizations.

ABRAHAMS: That's a good question. The staff was certainly a power center. I often described it as ACM's Civil Service.

NORBERG: I see it the same way. 
ABRAHAMS: And like Civil Service in any government, they certainly had a financial interest to protect, which was the funding of headquarters. That's where a lot of the overhead money went. Maybe that's where all of it went, as far as I can remember. So they certainly had an interest, I mean a very parochial interest, in this outcome. And it had been a subject of dispute for some time. I remember that. You mentioned that, too. And I think of this marvelous quote, I don't remember who it came from, about "The art of taxation is how so to pluck the goose as to get the maximum amount of feathers with the least amount of hissing." [Laughs]

NORBERG: [Laughs] That's good. Now, as I read this memo that McKegney had sent to various people, including yourself, that all the numbers here, the percentages and so on, deal with all of the special interest groups. So you'd have a pot of money, and if you had \$200,000 in the bank, you had to fork over $\$ 100,000$.

ABRAHAMS: Something like that, yes. But maybe it was based on cash flow, not on money in the bank.

NORBERG: That's what it says here, you were going to give 50\% back. But that's everybody. So your total pot here doesn't seem to be very big, considering how many special interest groups there were at the time.

ABRAHAMS: There were great differences in the wealth of the SIGs. Some of them were really pretty poor, and then there were others that were quite fat, like SIGGRAPH. SIGGRAPH was the fattest, and they made tons of money on their conferences, which led to all other kinds of issues too.

NORBERG: Did the general budget developed by the treasurer in consultation with all these people end up giving any of this money back to the special interest groups? Or projects that were new or whatever? Or did they expect them to live on the money they were bringing in?

ABRAHAMS: I think they were expected to live on the money that they brought in, although there was some sharing within the SIGBoard, as I remember. There was some crosssubsidization of different special interest groups. It was really quite an eye-opener to discover, when I got into all of this, how many of the issues and how much of the energy was consumed in these detailed financial things.

NORBERG: I've heard that from others.

ABRAHAMS: A lot of what happened-basically this is what happened in the meeting that I was in - was determined really by force of personality. You know, who was the better | negotiator? Who could stand up better? Frankly, I think McKegney_and Weinstein had me pegged. [Laughs] I didn't know. Years later I would have known...

NORBERG: But you had a financial advisor, and certainly there must have been other financial advisors there.

ABRAHAMS: They weren't at that meeting and I didn't know enough to make sure they were invited. 
NORBERG: Well, but didn't you have any preparation with them beforehand?

ABRAHAMS: Not that I can remember. I don't think that the meeting was exactly sprung on me, but I don't think I had any discussions with anyone else before this. I might have; I just don't remember. There certainly were discussions afterwards. On the other hand, I don't remember people jumping on me saying I gave away the store, either.

NORBERG: Because this was a meeting on January 13, '81, and it's a memorandum from McKegney the following day.

ABRAHAMS: I couldn't have been in that job more than six months, I don't think, at that point. One advantage the Headquarters people had in negotiations like that was that the volunteers were almost always new to the game, because of the turnover in elective offices, while the Headquarters people had been around for a long time.

NORBERG: Wouldn't there have been an ACM Council meeting in November, I guess?

ABRAHAMS: Yes, probably.

NORBERG: So that would give you two months or a month and a half.

ABRAHAMS: Yes. That wasn't enough. [Laughs] There was a lot to learn!

NORBERG: I'm sure there was. I don't want to press that too hard.

ABRAHAMS: One more thing I should mention that may explain it is, until I got on the ACM Council, I really didn't know much about the ACM Council. When I was SIGPLAN chair, I dealt with the SIGBoard some, and I dealt with the rest of ACM hardly at all. So I just didn't know how things worked. It took me a while to understand how things worked.

NORBERG: That was my next question, actually, in this section, is how did ACM work at the time? You're suggesting to me that you weren't really that cognizant of it.

ABRAHAMS: Not until I got involved as SIGBoard Chair.

NORBERG: That's the time I'm talking about.

ABRAHAMS: Yes. And then I got a much better sense of how the whole budgeting process worked, because the Council voted on the budget and got all these presentations on the budget, and fought over the budget, and that consumed a great deal of the Council's time, just dealing with all of those things. It was a very complicated document. It was made even more complicated than it needed to be. I think one of the things that went on was, when you look at the people who are on the ACM Council, some had management backgrounds and some didn't. I didn't. I'm not sure the ones who did really ultimately had a big advantage, but they certainly had an advantage in debate. 
I gained a much better understanding of a lot of these things as time went on. In fact, I think I made my own contributions to some of it. But they weren't contributions I could have made when I came in, because I didn't know enough. I really did a lot of on-the-job learning with these things, particularly when I was SIGBoard chair, because as SIGPLAN chair, I had dealt with SIGBoard, but not very much and not with the rest of ACM at all.

NORBERG: So in effect, you wouldn't have been cognizant of what the association was like at its higher levels?

ABRAHAMS: No, I wasn't.

NORBERG: Okay. What about the lower levels? What was the nature of the... How would you describe the ACM membership? Where did they come from? I don't mean specific places, but are they coming from academic backgrounds? Are they coming from industrial backgrounds? Whatever. Do you remember that part of it around 1980?

ABRAHAMS: Well, I have to think about it a little. But what I remember was that there seemed to be people who came in through the chapters, whose main association was going to chapter meetings. And then there are other people for whom conferences were a big thing. They gave papers at conferences, attended conferences. Then there were others for whom it was a publication, it was a subscription. So there were three groups, and they certainly overlapped a lot.

NORBERG: But where did they come from? Were the majority of those people academics?

ABRAHAMS: I would say that the chapters' people were not. Few of them were academics. The conferences people, most of them were academics, or quasi-academics like the people in outfits like IBM Yorktown Heights. Then the subscribers were a mixture of students and academics, mostly, the people for whom they didn't do anything except get Communications and maybe belong to a couple of SIGs.

NORBERG: And yet, if you look at the governing officers of the association from roughly 1974 to at least your time, that most of them - if not, I might say all of them except you —were practical types. They weren't academics. They were working for companies or non-profit organizations or the government. And that, it would seem to me, ought to generate some ferment at lower levels, that, "Hey, we're not taking care of the practical people. We spend too much time worrying about the research crowd and academics."

ABRAHAMS: There was a lot of that kind of discussion. Even within SIGPLAN there was this divide between the theoreticians and the pragmatists. I always thought of the theoreticians as being a little bit like British royalty, because they were really quite aristocratic in their own way. I'm trying to remember what I can about that kind of issue. You know, I hadn't really thought about where did all these presidents come from? There were some who came in from left field, frankly - Dan McCracken and Herb Grosch particularly. And also Brian Kocher.

NORBERG: I didn't know that. 
ABRAHAMS: Yes. Brian Kocher came from the chapters. I think he'd be a very interesting one to interview. Frankly, I think he was quite unsuccessful as president, but I'm sure that's not his perception. And to know how he saw what happened I think would be very interesting. I'll get to that a little later. Probably not even today.

NORBERG: Okay. I asked that question because it seems that in the special interest groups, that that problem was taken care of depending upon which group you belonged to.

ABRAHAMS: Yes.

NORBERG: There was a significant amount of technical content useful to non-academics in certain programs of certain SIGs.

ABRAHAMS: Absolutely.

NORBERG: Okay. So from their point of view, they would probably say, "We're doing fine. We don't need to worry about the management of ACM generally." But what kind of tension did this produce between the ACM Council and these special interest groups, chairs or the SIGBoard chair or whatever?

ABRAHAMS: I'm trying to remember. I don't remember any clear divide like that in the Council. The big divide I remember was between chapters and SIGs. At least that's what people were talking about. I thought it was a little bit artificial, but there was something real underneath it. A lot of it had to do with, again, where the money went and where it came from. Some of it had to do with the politics of who got elected. Will this candidate win the chapter's vote? Or will they win the SIG vote? Or will they win both? Certainly, there was lots of lip service rendered to the chapters. The SIG groups were always viewed as kind of the technical mainstays. Some of them probably may not have even been all that technical, as well as I can remember. There certainly were a lot of differences among the SIGs. I think the reason the SIGBoard chairman had so much influence and power was just because there was so much money sitting in these things. The SIGs unlike most other groups at ACM basically had control of their own money. Not entirely - they had to fork over to headquarters. But still, they had a lot left. And they had some cash cows there too, notably certain conferences. In fact, I don't remember if they really had much other cash cows other than conferences, but some of the conferences-SIGDA (Design Automation), that was another one that had very lucrative conferences.

NORBERG: I would think that the graphics people would too.

ABRAHAMS: Oh, yes. SIGGRAPH was the big one. The graphics one was a big, big one. And then after that came SIGDA, design automation. And then a little later in the game came SIGPLAN with the OOPSLA Conference (Object Oriented Programming Languages and Systems), which turned out to be a big moneymaker. But that happened after my time, the OOPSLA thing. I think it was just getting started when I was Chair of SIGPLAN. I remember there was one point where I was actually an officer on three levels. I don't remember whether I stayed...I was something in SIGPLAN, and then also I was vice president and SIGBoard Chairman for a short time. It created an interesting issue about approval of travel, because the 
vice president signed off on the travel of the SIGBoard chair, and the SIGBoard chair signed off on the travel for the next level down. And I was all of them! [Laughs]

NORBERG: Did that last very long?

ABRAHAMS: No, that didn't last very long.

NORBERG: Because there was a regulation within ACM, as I understand it, that you could not hold double positions within the administrative structure.

ABRAHAMS: Yes. Well, I know I did for a short time, but not for a long time.

NORBERG: Sure. I remember that came up with Michael Harrison too, when he was the SIGBoard chair.

ABRAHAMS: Yes.

NORBERG: You keep talking about chapters and special interest groups. What about the regions? The regions actually had a seat on the Council.

ABRAHAMS: They did, but there was no real unity to that that I could determine. It was really... I guess there may have been some history behind it that I never really knew about. But it was not really clear to me why the people in the region were any kind of a coherent group. I think there was the feeling that perhaps because there was some geographical basis to it, they were more closely tied in with the chapters than the SIGs. And there may have even been some campaigning among the chapters. In fact, as I think about that, it would make a lot of sense. If you're running for regional representative, a natural place to go campaigning is the chapters in your region. So it does seem natural that there should be a certain tie-in between the chapters and the regional representatives. I'm sorry I can't remember this more clearly, but 25 years does a lot.

NORBERG: What we're trying to do here, Paul, is that a template was developed in order to make sure the same kind of information (insofar as it was there to be had) came from all the past presidents. And since many of the issues in the organization transcended sometimes over a decade, that was not an unreasonable approach.

ABRAHAMS: I think it was a very reasonable approach.

NORBERG: Then when the individual interviewers-I'm certainly not the only one doing the interviews - looking at the person who they're going to interview then tries to manipulate those questions of that template to fit the person. So that's what I tried to do with yours. That folder I gave you has the whole set of questions that I'm working with here in addition to the two publication lists, which are now, I think, complete.

Now, back in 1975, Bernie Galler presented a reorganization of ACM. And I know you were not at that level at that time, so you probably wouldn't even be aware of what was going on in this case. I bring it up because Jean Sammet, who was the president at the time that Bernie did this, sent these things around to Council members, and it was several years before it was 
finished, that there was what could be taken out of the document, placed in the policies and procedures manual, and the rest just cant. If they opted to keep that at all. I have the impression that it was the officers of the organization that were behind the reorganization anyway, and also implemented it insofar as it took some time. And that Grosch sort up upset the apple cart by getting elected by being a petition candidate. And when he came in, he wasn't so interested, I gather, in these things. I'm not sure McCracken was either, but Denning was. That would be a time when there might be a significant amount of conversation between you and others.

ABRAHAMS: There were considerable fireworks between Jean Sammet and Herb Grosch, as I'm sure you've heard.

NORBERG: But you weren't there, so I can't really ask you about those.

ABRAHAMS: I think I saw the end of that, because I believe that when I first got on the Council, Grosch was president, and then Denning took over.

NORBERG: No. He was president from '76-'78, when McCracken came in, then Denning. The letters that Grosch would send, often they were very insulting, but that was Herb Grosch. But they also didn't lead anywhere. That's what used to make Denning mad, I think. Here were all these things he's throwing out as if they were really good ideas, and Denning didn't think they were good ideas at all. And usually he responded to them, and not very nicely. But I heard Brandin didn't respond very nicely either.

ABRAHAMS: No. In fact, he was designing letters, I think, for the very purpose of upsetting Herb. [Laughs] I had my problems as president with Grosch, too.

NORBERG: Oh, you did?

ABRAHAMS: Yes. I don't remember the details of the problems, but I do remember that at one point, I challenged him to a debate. And it almost happened. I don't remember why it didn't happen.

NORBERG: This is while you were president?

ABRAHAMS: While I was president, yes. He was a thorn in my side, too. I really felt that he was acting as a rabble-rouser.

NORBERG: He was that.

ABRAHAMS: Hmm, I can't think of... It's frustrating, because I have impressions, but not a lot of details sometimes to back them up. Or maybe it's more like random details to back them up. Because I guess I dealt with a number of presidents. I dealt with McCracken a little bit. With Denning quite a lot. And then of course, with Brandin and Goldberg, too. There's many a tale to be told about that, which I will be getting to.

NORBERG: We'll get to that, yes. 
ABRAHAMS: Although I guess right now we're really concentrating on my SIGBoard time.

NORBERG: Well, in those early years where I'm trying to get a feel for how you were inducted into the organization, so to speak.

ABRAHAMS: I was inducted by winning unexpected elections, which also meant that I often did not have the same history as other people in the job. But I told you the story of learning Hebrew in grade school. I was a pretty fast learner, but I didn't start out with much.

NORBERG: Were you a party to conversations about the nature of the association, the finances of it, in 1980, '81, '82, when you were giving up so much money from the SIG groups?

ABRAHAMS: I think I was. Because I think a lot of that took place at the Council level. There were a lot of discussions of that kind of thing. I do remember the fights about overhead. There were fights both between the SIGs and the rest of the organization. It was interesting that when Peter Denning became president, he had a very different take on all of this than when he was SIGBoard Chairman, which was to be expected. Where you stand depends on where you sit, I suppose. And I do remember there were also, I think, questions within the SIGs about how much cost subsidy there should be. Then there were a lot of questions, in particular about conferences, about overhead, and basically when a conference made a lot of money, where did that money go? How much went back to the SIG and how much went to the other SIGs and how much went to the big headquarters in the sky? [Laughs]

I'll get to some more details on this, but I think one of the things I did as president was to straighten out a little bit of the strange accounting, which is certainly not something I did because I have a background in it, but it just seemed weird.

NORBERG: But at that time, as I remember, the budget was pretty sizable, too. Three million dollars?

ABRAHAMS: Oh, yes.

NORBERG: So there were lots of places one could hide money.

ABRAHAMS: Yes. The SIG discretionary fund came up, I think, after my time. But that was one of the things that the SIGs did to try to use their money in a socially responsible way. I may remember other things as we go on.

NORBERG: Being SIG Board Chairman, did you have an impression about what group was benefiting more than others within the organization? I'm speaking now of organized groups, not people.

ABRAHAMS: Benefit in what sense?

NORBERG: Well, there are three ways, it seems to me, that the Council-any council of any organization that's non-profit — can operate. It can legislate about what the special interest groups can and cannot do. It can provide authorization to spend money, because the groups do belong to the ACM, after all, so you can't just go out and do what you damn well please. And 
thirdly, to sort of keep some sort of mutual viability, for I would say viability and fiscal responsibility as a pair, that the people at the top would see these as important parts of their task, their fiduciary responsibility, if you like. And when, say, the graphics group goes out and holds a big meeting and lots of people show up and it turns out to be a big success and they make $\$ 100,000$ or whatever, can they really say that they did this independent of ACM?

ABRAHAMS: They'd like to.

NORBERG: I'm sure they would like to.

ABRAHAMS: Yes. There was a secession movement in the artificial intelligence community. SIGART got into a big fight with Jean Sammet, which led some leading AI people to quit SIGART and start AAAI, the American Association for Artificial Intelligence. There certainly were a lot of resentments of the money that was being siphoned off to other sections of the organization. SIGGRAPH, I think, was generally pretty generous about this sort of thing. They could afford to be. There were questions about, for example, if an outfit like SIGGRAPH had their own pet projects, how much money would go into those versus those that were of more general benefit to the membership. And then you think about what ACM spent its money on? There were questions of general viability, like how much do we spend in membership recruiting? There were good-deed types of things. There was how much support is there for headquarters, which was always an issue. There were issues like moving, changing the headquarters building and moving from one place to another, which is a very expensive proposition. I'm trying to remember what sort of basically charitable enterprises did ACM get involved in. There was the ACM foundation, which came up at some point. I don't remember exactly when that came up. The idea that basically ACM would go around looking for noble causes in computing.

NORBERG: During Brandin's time.

ABRAHAMS: Yes. And I remember we even had somebody come in, a consultant of some kind, who was trying to show how this could be organized. I thought it was really pie in the sky, and I said so. Got a few people annoyed at me for that. Actually, what I remember, though I'm not describing it quite as it happened, I remember what happened was this guy came in and gave his presentation, and it all sounded very nice and very good, and I said, "Okay. So what next?" We didn't throw the idea out. But then when it actually came time to, in some sense, put up or shut up, he came up empty. Basically, I remember being very critical of him at a public meeting — he was an outside guy — and saying basically, "You promised us all this. You led us to think it could happen. And I feel I was led on." He felt very insulted, but he should have been! But he went away.

Jim Adams was the one who brought him in. You probably have heard of Jim Adams. Very nice guy, who I guess retired sometime while I was there. They used to call him Mr. ACM, and he was deeply devoted to the organization. He had come up through the chapters. He was, I think, some type of chapter chair or something, and then he went to work at headquarters. He put an enormous amount of energy into ACM. It was not just his job, it was his life. And very well liked, very talented. But in this particular case, I think he misjudged the guy who he was bringing in. 
NORBERG: Not uncommon. You raised the question of serving the members, and I wanted to pursue that a little bit more, because in any professional association, there are always problems with how to serve the members. Some people belong to an organization just to be able to get the journals at a reduced price, or whatever. Some belong because they want to move up in the administration of the organization, and they get some goodies for that. But what were the topics under consideration that the organization, the Council, hoped would make it a more attractive organization for people to join?

ABRAHAMS: I guess it was probably the basic things: publications, conferences, and chapters. ACM did not sponsor research, and nobody ever suggested it could. There were also things that kind of were considered for the good of the community in general and some which got very controversial. Like, I don't know if you-- probably somebody has talked about the whole business of the Committee on Scientific Freedom and Human Rights. Very controversial issue. There were a couple of people who were leading the charge on that. Aaron Finerman was one. I guess that issue came up a number of times when I was at the higher levels.

NORBERG: Ralston was another.

ABRAHAMS: Yes. And I remember there was a thing about Natan Sharansky, and the whole issue of how much should ACM get involved in political issues, and are they really political issues or not political issues. There were even questions about the tax status and that sort of thing. Looking back on it, several things strike me. First of all, ultimately it didn't matter at all, because things changed in the Soviet Union and they're on reasonable terms with Israel now. Should people go over there?

NORBERG: But you can't really use that as an argument for the discussions that were going on in the late ' 70 s into the first half of the 1980s.

ABRAHAMS: Well, in one sense, I think if people really got smarter, they might have seen some of these things a little differently. Because Sharansky was portrayed as basically a computer guy, and he wasn't. That's very clear when you're looking at what he's doing in Israel now. He was a politician who happened to be in the computer field. I was a little aware of that, but not fully aware of the fact that the computing connections of some of these people were overblown. There might be a case to be made for intervening, but not necessarily by ACM, and not necessarily very vigorously by ACM.

This whole issue of ACM's involvement in the political world is one that's been going on for years and will continue to go on. And it's not just ACM that gets involved in that. It showed up in a number of different aspects, which I could go into when we talk about the presidency part. We can get to that.

I wish I could remember more about my SIGBoard years, but I may think of other things.

NORBERG: Yes. Let me deviate for a moment. Do you have any papers that survived from those years?

ABRAHAMS: I wish I did. I was looking. So far I haven't found any. It's too bad. If you'd come here ten years, maybe even five years ago, I would have found a lot more. I found one 
thing just yesterday, which is the minutes of the Council and the executive committee just before I took office as president.

NORBERG: Yes. The papers that we have in the Babbage stop in 1982. So there were Council minutes, there were agenda, and there were financial statements and so on. So up to '82, I was pretty well primed for the kinds of questions. And then I started trying to see whether these issues continued on among subsequent officers, and they did. Denning remembered some of them pretty clearly. He also had some documents that he used to support his argument.

ABRAHAMS: I may find some more. I could give you these others because they've just been sitting in my files.

NORBERG: All right. How much are we talking about?

ABRAHAMS: Oh, just one. But it might be an interesting sample.

NORBERG: Oh, okay. IV can put that in my suitcase. That's fine. What were the concerns about the publications? Were they serving the members or not?

ABRAHAMS: Oh, yes. That was an issue. I tried to remember if there was ever a move to drop a publication. I can't remember that there was. The big question was often starting new ones and who would be in charge of that. Again, money was king in a lot of the silly questions about the Publication Board control over this. I guess that's where the proposals for new publications came from. And in some cases, they actually came from the SIGs and went through the pubs board, like TOPLAS (Transactions on Programming Language and Systems). That was one that happened, as I remember, in my time. Susan Graham was the first editor-in-chief of it.

I don't remember if there was ever really an organized overview of the ACM publications. They kind of grew up from the bottom up, mostly from the SIGs I think.

NORBERG: I've seen some surveys that were taken by the office in New York and tried to see who gets what journal and what sort of subfield they're in and so on. For a number of yearsand I'd like to say a decade, but I think that's probably exaggerating it — there was a discussion about the journal for all members.

ABRAHAMS: I remember that.

NORBERG: That Communications had gone into a single direction and was no longer serving all of the members as they had hoped it would do when it was first established in the 1960s.

ABRAHAMS: I don't think that it happened exactly that way. It was more it wasn't that the Communications moved; it was the membership that moved. Because the membership gradually became less academic, and communications stayed in the same place. I remember Mike Harrison used to complain that, well, Communications isn't worth publishing in anymore like it used to be. That reflected, I think, the move in Communications to try to be a little bit more relevant to the membership in general. I mean, you could just look at Communications in the ' 70 s versus in the ' 90 s. Even the cover. 
NORBERG: It was quite different, yes.

ABRAHAMS: And I guess the real thing-type question is when academic people did their resumes, a citation of a Communications article was quite potent, was quite valuable, back in the '70s. It became much less so in the ' 80 s and ' 90 s.

NORBERG: When I joined the faculty at Minnesota, I was given tenure in the Computer Science Department because of my association with the Babbage. And as a result of having tenure, I sat in on many evaluation meetings of new faculty - whether they should be promoted or not, or what sort of direction should their work take if they expect to gain tenure in this department and so on. It took me a long time to understand conference papers, Communications papers, SIG meetings of various kinds and so on because it was so foreign to me. Coming out of physics, that's not the kind of thing that gets evaluated for tenure. It's solid, refereed publications, and money.

So if the shift turned out to be in the group associated with ACM, then the journal for all members is a rather interesting idea. It would become like Physics Today or Chemical and Engineering News and so on.

ABRAHAMS: Yes. Well, $C A C M$ is something like that now, as far as I can tell.

NORBERG: Yes. I don't read it very often, so I don't have a clear picture of what happened after '88. But I did look at many of them before that.

ABRAHAMS: You've reminded me of something else. I remember I got very concerned at one point about the fact that it seemed as though the main function of the more theoretical journals was drifting into credentialing. I was not happy about that. I felt it really had a very distorting effect on the value of what was in it, because the journals were not serving the readers, they were serving the publishers. I remember even coming up with some proposals about what to do about it. I don't remember at what point I made these proposals; it may have been when I was president, even. But the main idea I had was that the problem lay in the reviewing process. And the right way, if you want a journal to be for even a specialized membership, but let's just say for the readers rather than for the authors, then what you want to do is to have typical readers actually doing the reviewing. They review for different things. In other words, the specialist could tell you is this technically sound? Have they done the right citations? All of these kinds of things that reviewers are asked to do. But the other ones, the reader reviewers are, does this seem to be significant? Is it understandable? What they don't have to ask is - maybe, in fact, almost define the reader reviews in terms of the questions they don't have to ask. They don't have to say whether it's technically sound or not. Somebody else does that. If you assume that there are also reviewers who do that, then a reader reviewer could just assume that the other guy said it's technically sound, so it is, and it has the right citations. I never got anywhere with that. But I remember at some point pushing that idea, maybe even put it into a president's letter. It still seems to me like the way to go. But there was a strong community against that because in academia, this particular function of the journals is considered very important. I think ACM has lost by that, because I think the journals would be better if they weren't regarded primarily as a credentialing device.

NORBERG: Well, but the academic world is feeding all of that. 
ABRAHAMS: Oh, yes.

NORBERG: They need that sort of credentialing in order to get promoted and be able to even get tenure.

ABRAHAMS: Well, it may be that there some journals that work that way, like Journal of the $A C M$, which at one time was not quite as theoretical as it became. Another question is, if you say okay, if ACM is really in the credentialing business, what's the best way to do that? And don't make a pretense of it.

NORBERG: Yes. And you're right that the professional associations should not be doing that, that's not their task.

ABRAHAMS: I would even argue it's not their task. But if it is their task, they should be doing differently than the way they are. To basically involve the readers in this bit of a charade to me seems not right. It still seems not right to me.

NORBERG: Would you say the same thing is going on in proposal writing and the awarding of grants to people, or contracts as the case may be? They go out for review to people who say that it's technically competent.

ABRAHAMS: Probably so.

\section{END OF SESSION ONE}

\section{Session 2, Tape 1, Side 1}

NORBERG: October 16, 2007. I am in the home of Dr. Paul Abrahams for the second session of our interview about ACM and about computing matters.

ABRAHAMS: A question you asked — and I thought a little bit about it - which was interesting, about what were the strength of the math department, and I realized that as an undergraduate, I didn't know and I didn't care. The strengths of the department don't really start to show up until you're in graduate school because you're not taking a lot of specialized courses. And then there were a whole bunch of things in that red folder that were quite thought-provoking. It led me to

think about one interesting question, which was, why do people want to be president of ACM anyway, and what difference does it make? How much does a president do, really? What is the role of a president? Who have been the better ones and the worse ones? I think a president is sort of like a captain of a ship: you steer it, but basically, you don't really set the itinerary. Like a big ship, there's an awful lot of organizational inertia. I started to think about-you know, maybe I just don't remember. One of the questions was what did I accomplish? And the obvious follow-on is what did anyone else accomplish? 
NORBERG: Okay. Can we leave that, though, until we get to the end of the presidency?

ABRAHAMS: Sure.

NORBERG: I have a few things that came up in my listening to you. First of all, Project MAC was somewhat glossed over yesterday. Is that because you were not very familiar with it, or it started too late for you, you were already gone?

ABRAHAMS: It started too late for me. It really, I think, just started to get going about the time I was in the late stages of my dissertation. I don't remember exactly where it was organizationally or where the money was coming from, but basically, my contact was with the artificial intelligence project. That's where I hung out, that's where I spent my time, and that's where I was focused.

NORBERG: Okay. I wanted to clear that up to make sure to make sure that I hadn't missed something in the process.

ABRAHAMS: Yes. I knew people in there. You know, it was in the same building, and they were using the same computer. I guess, eventually, it became-- I don't remember the timing of it becoming Multics, but I knew people who were involved in that.

NORBERG: All right. There are a couple of timing issues of when things happened and in what order that came up, and the most significant ones on yesterday's tape have to do with the organization of the SIGPLAN Conference on Symbol Manipulation, and how you arranged for rapid distribution of the Ada language definition. How did this all transpire? First of all, let's just take the conference first.

ABRAHAMS: Okay. The conference happened...I'm trying to remember, ' 80 or ' 81 .

NORBERG: It was that late?

ABRAHAMS: What I remember was kind of interesting. I was the conference chair as well as chair of the Program Committee, so I was involved in the selection of papers and all of that kind of stuff. What I remember was that there was material that had to be mailed out - I think it was to the Program Committee or something like that - and I did it on this very table. I moved into this house in 1980, so I figure anything that happened, it had to have happened after August 1980. It could have actually been later that year. I don't remember what...

NORBERG: That's fine. That gives us a benchmark, at least.

ABRAHAMS: Right. I remember being very proud of that conference. I initiated it and I felt it was quite successful. Other people felt it was quite successful. It was filling a gap. There was this whole issue within SIGPLAN of the theoreticians versus the pragmatists. The theoreticians basically had been running the show. They were the ones who determined, really, the content of the flagship conference, which was the Principles of Programming Languages Conference. I didn't really want to try to change it so much as to add another one, which I think was how the 
compiler construction conference came about. And that worked very well. Everybody had their own house to play in, basically.

NORBERG: Did you give a paper at that conference?

ABRAHAMS: No. In fact I shouldn't have, because generally conference chairs are discouraged from doing that because, you know, how do you evaluate them? Generally, in fact, Program Committee members are discouraged from contributing papers.

NORBERG: At any conference?

ABRAHAMS: Pretty much. Because otherwise, the whole issue of the partiality of the judgment comes up.

NORBERG: Okay. So you're guessing that that occurred somewhere around 1983, are you? When I sent you the original list of publications, you indicated that this was one of the things that you had not contributed to. You only organized it.

ABRAHAMS: Right.

NORBERG: And I thought it was '83.

ABRAHAMS: No, it was earlier than that. It happened much earlier than that. It was around...possibly ' 81 , but in fact, I think it was 1980. Maybe the answer to the timing was I had only been living here a month when I did it. But that's something we should be able to verify objectively.

NORBERG: Here's the "Proceedings of the 1983 Annual Conference on Computers: Extending the Human Resource." ACM '83. No, this was in '79. The 1979 SIGPLAN Symposium on Compiler Construction.

ABRAHAMS: Right. That's what I got going.

NORBERG: Okay. And that's different than the meeting we're talking about.

ABRAHAMS: Right. Yes.

NORBERG: We can pin that down because I have the original e-mail you sent me about what changes you thought should be done. All right. Now, how does this phase into Ada and the Ada definition?

ABRAHAMS: Well, that was independent. It happened around the same time, but it was not related. Since Ada is a programming language, obviously SIGPLAN had an interest in this. The whole Ada project was a project of DoD. They ran a competition for who could design the language. Last night, I was just checking on the history of that, and I found some-in fact, you could verify it because if you look at Wikipedia of Ada, it has the whole history of how this 
competition came about. It may not be worthwhile my going into that just because you can-- Or you could check. I can check on it in two minutes here.

NORBERG: Yeah, but I'm trying to get the thing straight because yesterday, they blended into each other on the tape.

ABRAHAMS: No, they're different. I guess the key fact was that there was a competition, there was a decision to be made by DoD, so nobody knew what the language would be until this decision was made. I felt that it would be a real coup, once the decision was made, to get the language definition to the hands of the members real fast. And I did.

NORBERG: Then the last point under this category was the compiler construction conference. That's what you started out with this morning, right?

ABRAHAMS: Right.

NORBERG: You just mentioned that.

ABRAHAMS: Yes. There was a point at which I thought-- well, earlier, where I thought, well, the thing to do is to bring more of a pragmatic element into the POPL Conference-Principles of Programming Languages. And then I realized, first of all, it's going to be very difficult because people will be resisting it. Secondly, why ruin a good thing? Just create another good thing. Because if this is serving a certain part of the SIGPLAN membership, and actually, it was SIGACT too, the automata theory people, if it's really serving their needs, why tinker with it? Add to it. The money was there. The people to go to the conferences were there. So, it seems like a natural thing. But nobody had done it before me.

NORBERG: Sure. I want to ask again about the first long-range planning meeting that you organized.

ABRAHAMS: Oh, SIGPLAN? No, it was SIG Board.

NORBERG: Yes, of the SIG Board. Now, how many people attended that Long-Range Planning conference?

ABRAHAMS: About ten, as I remember.

NORBERG: And who were they? Not by names, but by offices.

ABRAHAMS: Basically, it was the members of the SIG Board. There may have been maybe one or two other people who came for some other ex officio kind of reason, but basically, it was the members of the SIG Board.

NORBERG: And what was the purpose? I know what long-range planning suggests to us, but what did you see as the reason for the need of such a conference? 
ABRAHAMS: Having chaired a couple of SIG Board members, I felt that, basically, we were spending all our time on little stuff. There was never really time as a group to look at the larger issues of where we're going and that kind of thing. So I felt that, just so we could get a better sense of direction of where we were going, we would certainly greatly benefit from a kind of retreat where we could, in an informal way without a really rigid agenda, just look at the issues. You know, what sort of things should the SIG Board be doing, should the SIGs be doing? It still, unfortunately, at a certain point drifted into discussion of the small stuff. You know, little issues that had been bugging people came up, and then we spent too much time on them. One thing I remember about the meeting was, I think we started in the early afternoon and it went on to the evening, which didn't bother me. I felt that was fine. And then it was still running after midnight, which was still okay for me since I'm sort of a night owl, but other people started to get tired. There was a feeling that the meeting was good as far as it went, but it never really finished.

NORBERG: How many of these did you organize?

ABRAHAMS: Only one, as I can remember it.

NORBERG: Did your successor organize one as well?

ABRAHAMS: Yes. There were others, but then it started to quickly change character into just another SIG Board meeting, which I thought was sad because people felt, "Well, there wasn't enough time at the other meetings, so let's do all our administrative work here." Basically, that was really the end of long-range planning partly because once it became more of an open meeting, which the SIG Board meetings were, and other people were in the room, then the whole nature of the discussion changed, partly because it wasn't just the SIG Board people who were chiming in on the conversation. ACM has this tradition of meetings where it's not just the people on the committee that's meeting who get to talk at the meetings.

NORBERG: Sure. Yes, that's a pretty common idea among-- except for very large organizations, I think it's pretty common.

I'd like to move back now into what we talked about yesterday and continue it a little bit. There were two things that occurred to me when I was listening to the tape toward the end last night, and I'd like to explore these with you again. And that is, you were pretty firm about the order of succession, that many of the subsequent presidents had been chair of the SIG Board.

ABRAHAMS: That's right.

NORBERG: Now, what's in between that? There's almost nothing, is that right? There are these few boards that are equivalent: Publications, SIG, and Members and Chapters, I guess. There's that, and then you move up into the offices: the Council and then the officers of the organization. So in fact, it is a likely result.

ABRAHAMS: Stepping stone. 
NORBERG: Yes, or stepping stone, right. And I didn't catch that yesterday when we were talking about it. I listened to it last night and thought, "Yes, he's probably right." But does that make it seem trivial, then? That somebody moves up to be president? What's the big deal?

ABRAHAMS: No, it's... Well, I guess my two models in this that I can remember were Dave Brandin and Peter Denning, who both took the same route. I don't remember if Dave Brandin was ever vice president or not--

NORBERG: I think not.

ABRAHAMS: Yes. He certainly was SIG Board chair. And I believe that Denning was vice president once.

NORBERG: Yes, he was, under McCracken.

ABRAHAMS: Yes. And I think there may have been one or two before Denning, but I don't remember for sure.

NORBERG: The last thing that occurred to me listening to the tape, how did you know that you were considered a shadow candidate when you were running? [Laughs]

ABRAHAMS: At the time, I didn't.

NORBERG: But why say it now? What is it that has occurred to you since?

ABRAHAMS: Well, the first thing was that I realized that that was a very common custom. You don't tell the shadow candidate they're a shadow candidate, but it very often happens. The requirement is that you have two candidates, and you know who you want to be the next one, so you get that person and then you pick somebody else who doesn't seem totally unreasonable.

NORBERG: That's rather cynical. [Laughter]

ABRAHAMS: Well, that's how it worked. You know, the shadow candidate may be more or less of a real candidate, and in some cases they win, which is why you certainly don't want to have a bozo as shadow candidate. [Laughter]

NORBERG: But if you think back to when Grosch was running and when McCracken was running, each of them for president, indeed, McCracken a vice president, that these were petition candidates who won. And I was having a little bit of trouble getting Denning to think back on it, because I haven't talked to McCracken yet. But having trouble getting him to think back at what was the issue. Why was it necessary to have petition candidates? As I read the letters in the forum about elections - some from you, some from Denning, some from other people. It seems as though there was a fear-I'm maybe stating this too strongly now-but it seemed to me that there was a fear that what was happening was the good old boys were getting elected and reelected and taking care of each other. Grosch felt, as he said in a letter, rather miffed at this process, and so he put his own name forward and got in on a petition - signatures and so on. The same thing for McCracken, although McCracken is a little bit more low-key about it. But I sense 
he's in the same sort of quandary that Grosch was. Now, here are two people who get elected. I don't know what you'd say about Grosch as president; I can't imagine he'd be a very good one. But McCracken, I think, was.

ABRAHAMS: Grosch was entertaining, anyway. [Laughter]

NORBERG: Well, that may be. That may be. McCracken, I think, was very serious about it, and probably overly serious about it. And then we come into Denning, who was, as you said, rather forceful. And Brandin, who, in my talking to him anyway, gave me the impression that he was just trying to be a good president.

ABRAHAMS: I think so.

NORBERG: And not worry too much about what other people thought about what he would do.

ABRAHAMS: He has a very powerful ego in that sense. He's one of the most self-assured people I've ever known.

NORBERG: I can understand that.

ABRAHAMS: I think he was a really good president. In Council meetings in particular, he was the best Council chair I can remember. As I went through all of this, I felt that the smartest thing I could do would be to learn from other people. I learned a lot from him, and I learned a lot from Peter Denning. Even though I had a lot of arguments with Peter Denning, I learned a lot from him. But he may not have intended to teach me. [Chuckles]

NORBERG: Sure. What were some of those arguments with Denning? Can you remember them?

ABRAHAMS: The big one was when I was SIG Board chair, and there would be arguments about the money. I found that very interesting in a way because he had been a SIG Board chair, so he had been on the other side of the fence, and it seems as though where you stand is where you sit [laughs], like the saying goes.

NORBERG: That's like university presidents. [Laughs]

ABRAHAMS: Yes, yes, yes! And that was the big one. There was also another interesting side of arguing. It never really came out very clearly, but Peter is extremely conservative politically. I don't know if anybody even told you that.

NORBERG: No, and I don't think he did, either.

ABRAHAMS: He wouldn't. [Chuckles]

NORBERG: I didn't sense it in him. We had a couple of personal conversations during the course of this - and I mean personal outside of the interview process - about our separate lives. He was rather forthright in those. I think he was trying to get some information from me that 
might help him to understand some things that he was facing at that time. But they were very good. He never gave me the impression it was politics, nor did he suggest anything about being conservative or not conservative.

ABRAHAMS: I guess I regarded this perhaps more as amusing than really a source of conflict, but it was very... What I remember was that there was something that happened - I don't remember whether he gave me a subscription to it or what, but National Review, Buckley's magazine.

NORBERG: Oh, that's a tip-off.

ABRAHAMS: Yes. There was something about that, so my response was to send him a gift subscription to The Nation. [Laughter]

NORBERG: Did he give a reaction?

ABRAHAMS: He never said anything about it. Not a word. [Laughter] I guess my view of it is there's nothing wrong, if you're liberal, with reading conservative publications. In fact, there may be an advantage to it.

NORBERG: That's why I read the Los Angeles Times once in a while.

ABRAHAMS: Yes. And then the other tip-off - although this is a much more subtle one - was his going to George Mason University, which is involved in various conservative causes, I understand.

NORBERG: Yes, I don't know. We didn't talk much about George Mason. We talked only about his activities while he was there.

ABRAHAMS: Yes. The other thing that I learned from Peter-- well, I wouldn't exactly say I learned it, but I was certainly impressed by it. He is one of the best writers ACM has ever had.

NORBERG: Well, I sensed that in reading his various presidential letters and editorials of the Communications. It almost made it seem as if he'd missed his calling, actually, that he was doing the wrong thing and should've been doing something else, but I didn't ask him that question. That seemed like it would be rather insulting, perhaps, or at least presumptuous on my part.

ABRAHAMS: Well, Einstein once thought he might have done better as a plumber. [Laughter]

NORBERG: All right. Let's get back to where we were, then.

ABRAHAMS: Oh, actually, the other thing is, I think that when he said that, he was given an honorary membership in the plumbers union. [Laughs]

NORBERG: Okay. I've never heard that before. 
ABRAHAMS: I may not have the story exactly right, but something like that.

NORBERG: There's no way to move this topic into any particular area of this series of questions, so let me just ask it and we'll come back to it as we need to. What I composed here was, computing has always been a multifaceted field, and even during your tenure it was represented by a number of different organizations. What was your opinion about these other organizations throughout the 1980s? AAAI, AFIPS (that will be a serious discussion, I should think), DPMA, the IEEE Computer Society, and then the one time that you people went to see ACS to see how they operate.

ABRAHAMS: Ah, okay. We could talk about them one by one. Let's just go through the list again. What was the first one?

NORBERG: AAAI.

ABRAHAMS: Was it artificial intelligence?

NORBERG: That's correct.

ABRAHAMS: Okay. Again, all this happened years ago. ACM had a group, SIGAI, or the Special Interest Group on Artificial Intelligence. Some of the people in that group, as I remember it, they rebelled or something or they didn't like the way things were going. There was a fight with Jean Sammet over money.

NORBERG: Was this in the '70s, or later?

ABRAHAMS: Late '70s, I believe.

NORBERG: Okay. She was past president under Grosch from '76 to '78.

ABRAHAMS: But she was somehow involved in this. This whole question of...I don't remember exactly what it was, but something about-- it was almost like people had to sign a loyalty oath. It wasn't really that, but that was the spirit of it. It was some kind of a commitment that people were supposed to make to ACM.

NORBERG: As people, or as members of a group?

ABRAHAMS: I think it was as members of a group. It was nothing totally unreasonable. Basically, AAAI, as I remember, and I may remember this totally wrong, was organized by rebels from the ACM Special Interest Group on Artificial Intelligence, because they didn't like the constraints that were being placed on them by ACM. It may have been something like they wanted to run a conference and keep more of the money. It could have been anything like that. I don't remember anymore what it was, but I remember that it maybe even had to do with the use of the name of ACM, or something like that. But what I remember was that Jean Sammet was on the other side, whatever the issue was. So they rebelled and they started this other group, and then there was always this competition between the two groups. I haven't really followed the field, even though it's what I started in. My guess is, like so many other such things, they 
eventually found a way to coexist. I mean, I don't really know much about them. I didn't know that much about them even then. My impression was that they were basically-- it's kind of like the CIO and the AFL. You know, they broke off because they had their own ideas on how to do things in their special interests, but they were still part of the same general movement.

NORBERG: Yes. Let's leave AFIPS aside for the moment.

ABRAHAMS: Oh, yes. AFIPS is a different kind of party.

NORBERG: That's right. How about DPMA?

ABRAHAMS: We had some interactions with them, but basically, I think they were considered a little bit lowbrow, is maybe the way to describe them. They were basically managers; they weren't really very technical people. So there was very, very little intellectual interaction. The interactions, which came about partly, of course, through the AFIPS stuff, were almost entirely administrative and political. There was nothing intellectually in common between the two groups, as far as I can remember.

NORBERG: The two groups. DMPA and ACM.

ABRAHAMS: People didn't even socialize much from the two groups.

NORBERG: When you were vice president and Brandin was president, there were several discussions-I don't know whether they were just hallway discussions or what - with Oscar Garcia of the IEEE Computer Society. I guess it was Brandin who went about trying to link the two in a somewhat tighter bond.

ABRAHAMS: Yes, they were talking about merging. Lot of talk about merging.

NORBERG: Okay. Were you part of those discussions?

ABRAHAMS: I probably was, but wasn't central to them because I remember the issue, and I remember what some of the problems were. It got kind of a quarter of the way, but the biggest problem, not the only one, was that the Computer Society is part of IEEE, and ACM did not want to be part of IEEE.

NORBERG: And they were unwilling to leave IEEE?

ABRAHAMS: Well, I think there were some people who might have, but when you leave home, you have to leave all your assets behind, pretty much. [Laughter]

NORBERG: Well, that I can certainly understand. And then there's the ACS, which occurred in February of ' 88 . That is, a publication about it, February of ' 88 , by Dennis Frailey, your vice president. What I wanted to ask specifically about that one is, Frailey makes a number of suggestions in that letter, as ACM vice president, about what the organization can do and why ACS had these particular characteristics, and should ACM be thinking of the same thing. What I 
wanted to ask you is, since he was vice president, did you agree with the view that he expressed in the letter? Or was that just his?

ABRAHAMS: I don't remember the letter. My memory of it... [Looks through papers] Okay. I'm going to look for a minute. Okay. The question you didn't ask is how did this meeting come about?

NORBERG: Well, I'm glad you reminded me then because I didn't think of it.

ABRAHAMS: That's really the right starting point.

NORBERG: Okay, then let's start there.

ABRAHAMS: One of the things that ACM presidents get to do is to be members of CSSP, the Council of Scientific Society Presidents. I don't think you've even heard about that one.

NORBERG: Well, I can tell you I have. The reasons are rather complex, I think.

ABRAHAMS: Yes. It's a very interesting organization in many ways, and I'm not sure I know the entire history of it. And I have, in some ways, a rather cynical view of it. The cynical view is that the American Chemical Society is an economic group. You know, they do lobbying and all that kind of thing. In fact, Eric Lieber is a Washington lobbyist, and so is his wife, as I remember. Basically, ACS set up CSSP. They were the ones who hosted the meetings and provided all the facilities. They provided administrative support. They also were very powerful, even within the running of the thing. I remember one guy in particular, I think Warren Niederhauser, who was one of the ACS representatives. The whole idea of it, I subsequently decided-- I mean, not that it was totally bad, but the motivation by ACS was to give themselves kind of an extra "in" in Washington. You know, to use the prestige of this group to push their own agendas. The meetings had a great deal of ego stroking in them, including members of Congress and all of that kind of thing. I remember one of the big controversies was that Philip Morris tried to have some representatives on it as industry liaisons, or something like that. Ultimately, the group said no.

I was fairly active in it, and I remember being a little bit frustrated because it seemed that ACM was putting in a lot more money than it should considering how much influence and votes it had. It was kind of a weird organization. For example, it had a lot of representatives of science teachers, who were certainly not researchers. They had some very distinguished people on it, and excellent speakers. I remember Anthony Fauci from NIH. So the meetings were very interesting. Anyway, that led to my having a lot of contact with ACS just because the meetings were in their headquarters, and the ACS people were hosting things and running them. Eric Lieber, in fact, had a party for everybody at his house in the suburbs. Beautiful house. Beautiful wife. [Chuckles] When I learned things about them, I just said, "Gee, there might be some things in common between ACS and ACM." So basically, I, as I remember, got this meeting going. Just to kind of share ideas.

The other thing I remember about it, which must have been very frustrating to the ACS people, was they apparently had a whole list of presentations they wanted to do. They had it all organized. We wanted to ask questions, so we wanted, basically, a very unstructured kind of meeting. Everybody ended up a little bit frustrated by that. But it did seem that there were a lot 
of things in common between ACS and ACM at the time in terms of how they related to the field. I remember an issue about how to-- I don't remember much about the issue except that it was a question about how chemical engineering relates to chemistry, and that seemed to have a little bit of similarity to how does mathematics relate to computing. Let's see. What was the original question?

NORBERG: It had to do with Frailey's letter describing this meeting and what you people had learned and some suggestions that were included in that. I was asking whether or not you agreed with those suggestions.

ABRAHAMS: Okay, and I should look at the suggestions again because those I don't remember. I just remember the context. [Reads letter] It was interesting also that there was a similar split among the psychologists — clinical versus experimental. The two kinds of psychologists belonged to separate organizations.

NORBERG: It seems to be a very common phenomenon now.

ABRAHAMS: Yep.

NORBERG: Did I mark the suggestions with a red check pen? They were toward the end.

ABRAHAMS: Okay, well I'll just go look at that. [Reads letter] Wait, I don't see the red marks.

NORBERG: Okay, but I asked if I did any. I didn't?

ABRAHAMS: No, you didn't.

NORBERG: Okay. Well, as I recall, it had to do with improving the staff capabilities in the hopes of adding staff as well. It was being more solicitous of members of the entire organization, just as the ACS people were. Then to consider whether or not it should do any education of the public, education of the legislature, and therefore should it be doing any lobbying. In 1969, before this, there was a survey done of members of the ACM. The survey asked a question about whether ACM should be doing any lobbying, and the majority of people who voted said absolutely not. So this is introducing the topic again ten years later, roughly.

ABRAHAMS: And it keeps coming up in different guises and different issues. I'll get to that, too, about the whole thing about the computer consultants and the tax stuff. But that's a president's issue, and we haven't gotten to that stuff yet.

NORBERG: Right. What made you decide to become the ACM vice president?

ABRAHAMS: Partly, I think it just seemed like a natural succession. You know, there's a deeper question there, which I thought about. Why did I want to be president? Why did anyone want to be president? And, of course, what people will say for the record is, you want to be president because you want to perform public service. The very cynical answer, which I think is 
ultimately Herb Grosch's answer is you want to be president because you get to travel to all kinds of nice places and stay in nice hotels. [Laughter] That's the cynical one.

NORBERG: Well, it is cynical.

ABRAHAMS: But there's something in between now.

NORBERG: It is cynical because all that money that gets drained off for those purposes cannot be used for upgrading the services to the members certainly.

ABRAHAMS: Yes. But there's actually an answer in between. I suspect it applies to a lot of people, and not just me. People get pleasure from doing things they do well, and ultimately, I think the reason I did any of this was the feeling that I could do it well. There's a certain satisfaction, and it's a selfish kind of satisfaction, but I think it's ultimately useful to the organization of feeling, "Well, I could do this well, so I'll enjoy doing it." That just feels good to know you're doing something well, and I think that's ultimately what motivated me and motivated most other people who did this.

NORBERG: What sort of groups of people nominated you for the election?

ABRAHAMS: Oh, I ran by petition. You didn't know that.

NORBERG: No, I didn't.

ABRAHAMS: Yes. There was the whole interesting tradition of the petition candidates versus the nominated candidates, and the petition candidates have generally, but not always, done well. And you can look at who they were and where they came from. I think Grosch was petition. I don't know if--

NORBERG: He was.

ABRAHAMS: McCracken was petition.

NORBERG: He was a petition candidate for vice president. I don't remember that he was a petition candidate for president.

ABRAHAMS: No, he wasn't. He was nominated for president. Let's see. Bryan Kocher was petition, and I think there may have been... See, there were four that I can think of: me, Kocher, McCracken, and Grosch. And there may have even been others, but those are the ones I remember.

NORBERG: Why do you think that was the case for ACM? What was the discontent that would lead to this situation?

ABRAHAMS: You mean the people running by petition?

NORBERG: Yes. 
ABRAHAMS: They wanted the job and felt they deserved it. Simple as that. [Laughs]

NORBERG: Wow. But you have to make a case for that.

ABRAHAMS: But that's exactly what motivates you. The other thing is, how do you get to win the election. And it was a very interesting election. You probably never heard any of this.

NORBERG: No, I didn't, and I noticed you mentioned that in the notes you gave me yesterday.

ABRAHAMS: Yes. Remember I mentioned Nina Knyphausen. She comes into the picture again. This is the Nina Knyphausen story.

NORBERG: “Comes again”?

ABRAHAMS: Oh, comes into the picture, I should say. Very, very interesting story.

NORBERG: Be my guest.

ABRAHAMS: I wasn't nominated because the Nominating Committee had someone else in mind. I can't remember for sure who I ran--- I remember one person I ran against. I think there were three or four people in that election.

NORBERG: This is the vice president election.

ABRAHAMS: The vice president election. Michael Harrison and Seymour Wolfson were the two nominated candidates. I and Kathleen Wagner got on the ballot by petition. Petition candidates never get into the picture until the nominations are announced. Mike was the intended winner, and Seymour was the shadow candidate (remember what I was talking about earlier). Seymour treated his own candidacy as a joke, almost. Not that he wasn't competent or anything, but he saw so little of chance of winning that he made a joke of it. Kathleen Wagner was secretary, I believe, and she came from the chapters. I put a lot of energy into my campaign. I felt I would really do the job well, and I think ultimately I did. But it wasn't my turn yet, I think that may have been the view of the Nominating Committee.

NORBERG: I don't know. I know Mike was an officer during the Denning years and later.

ABRAHAMS: He was also SIG Board chair before me. It all gets a little incestuous. Anyway, the story of that election is fascinating. I wish I could remember it better. I won it for the same reason I won a number of other elections: I was very good at writing campaign statements. But it turned out that there was a rule about the campaign statements that you're limited to 250 or 300 words. It was a word limit. When I won, Kathleen Wagner accused me of running over the limit in words, which immediately got to the question of, who counts the words? And that's where Nina Knyphausen comes in because she was the secretary in Pat Ryan's office, Pat Ryan being...I forget exactly what her title was, but some kind of administrative title. Pat is a very talented lady, by the way. So, poor Nina. She was just a secretary, and she got thrust into the spotlight on this because her question was, "Do little words count?" [Laughs] "A," "the," "of." 
[Laughs] Or, do words with less than five letters count? And there's a school of thought that says when you're counting words in something like this, you don't count those words. So Nina told me my statement was okay, and I relied on that. And then Kathleen claimed that I had been improperly elected. [Laughs] Fascinating story.

Kathleen was not a very popular lady, by the way. I can tell you other things about her, like her actions led Council to enact a rule to prevent people from doing what she did, which was to go directly to the ACM lawyers about things, justifying it by her position as ACM Secretary. And so there actually was a Council resolution on who gets access to the ACM lawyers, and that was directed at Kathleen.

Anyway, there was a Council meeting on this subject of was I properly elected? I was kind of hoping Dave Brandin would take my side, but he - and I can understand why - he just stayed neutral, even though I'm sure he was much happier to see me in than Kathleen. Same thing with Adele at that point. I think she also stayed neutral.

NORBERG: But what kind of an officer was she then?

ABRAHAMS: She was secretary when I was vice president and Brandin was president. And that whole other thing that-- We'll get to those stories. But anyway, this election was fascinating. You can imagine what the Council debate must've been like. I don't remember the details of it, but I remember I tried to approach it with a certain amount of humor, and I remember Jean Sammet said to me at one point just before that, "Why did you do such a meshuggeneh (Yiddish for crazy) thing?" [Laughter] So, when I was speaking during this debate, I quoted Jean Sammet. [Laughter] And yeah, she was right. If I had only known, I would have done it differently. But I relied on Nina. Nina told me it was okay, and that was her job, to say it was okay.

NORBERG: Is that process still in use today?

ABRAHAMS: Oh, they do it much better. Character count, so there could be no question.

NORBERG: Do spaces count as a character?

ABRAHAMS: Yep. Basically you typeset it (the line width is specified), and then you count the characters. Once that came in, then there were never any more arguments about it. So since I became vice president, I obviously won that particular debate. Kathleen was popular among a few people, but not very many. So that's basically how I got to be vice president.

NORBERG: Well, this suggests that there was really no strong relationship between you and David Brandin.

ABRAHAMS: Not at that point. I mean, we knew each other.

NORBERG: Sure. Yes.

\section{Session 2, Tape 1, Side B}


ABRAHAMS: Dave could be very pushy. Not necessarily in a bad way. I mean, I think it's related to self-confidence. I even had a friend once who at some kind of an ACM meeting, and he started electioneering. She basically asked me afterwards, "Who is that guy?" [Laughs] I mean, he had no shyness at all about that sort of thing, and it got him a long ways. He is a very talented guy, and I have a lot of respect for him. At the time I didn't like the way he did that. It was a little distasteful, may be the best way to describe it.

NORBERG: Well, what relationship did develop between you and Dave?

ABRAHAMS: That's a story. The relationship on the Executive Committee was extremely difficult. Adele and David were thick as thieves. They also had this heavy management background, which I didn't have. So basically, they were running the train and I was hanging onto the caboose. [Chuckles] They considered me to kind of be a drag on what they were trying to do.

NORBERG: How was that expressed?

ABRAHAMS: It was expressed by them basically running the Executive Committee meetings and talking to each other all the time in the meetings and offline. They were personally friendly. They were professionally friendly. They saw a lot of things the same way. So, I really felt very left out. And I was resentful at the time because I felt I was being mistreated, that the Executive Committee was really running as a group of two and not a group of three. I think from their standpoint, I was just a drag on their accomplishments. I didn't understand, I was naïve on all these sorts of things, they felt, though they never said I was. They brought me in on meetings of the Executive Committee and the Extended Executive Committee. The Executive Committee was the three elected officers, and the Extended included the treasurer and the past president. So there were just a few official meetings of the Executive Committee itself, and that's basically when they told me what they had decided about one thing or another. And there were decisions (I forget when it was exactly) about hiring a new executive director. It came in sometime around then, but it may not have been in that administration. I don't remember for sure.

NORBERG: What were your duties as vice president, then?

ABRAHAMS: I think I was basically chair of the Board chairs, as I remember. It was some kind of a body, which consisted of the chairs of the various boards, and I was in charge of that. I don't remember much about what I did. In fact, my memories of the vice presidency are pretty vague altogether except for the election, which has to be one of the strangest elections in ACM history.

NORBERG: Well, I don't know about that because there seemed to be an awful lot of strange ones.

ABRAHAMS: Yes.

NORBERG: Now, did this sort of cold shoulder, I'll call it, continue throughout the two years? 
ABRAHAMS: Yes, about as well as I can remember. I won't say Dave and I had a close friendship, but we were certainly on good terms. He always seemed busy. I never really got to talk to him very much, but when we did talk, we had good conversations. Once I was done with the presidency and everything, we had a perfectly good relationship. I remember several times we had a dinner together or something like that, but he was always rushing off to somewhere else and got there late and left early. These were not dinners that he-- you know, it was not official or anything, so it was not like he was being dragged kicking and screaming into them. And he was one of the people I learned a lot from. Among other things, he was probably the best chair of the Council that I can ever remember. He was extremely good at that. I felt that I could learn a lot from him about that, and I did. He ran meetings like nobody else before or after, as far as I know. It's easier to run the meetings now because the Council's smaller.

NORBERG: I see. When the term as vice president was over, what happened in terms of nominations and running and so on?

ABRAHAMS: Ah, another good question. At that point, I was interested in becoming president. It seemed like the natural thing to do, even if I had to run by petition. I felt I had done a reasonably good job as vice president, even if I can no longer remember what I did. But basically, people spoke to me and said, "You know, we really would like to run Adele," and I figured I was not going to win an election against Adele. And so they gave me the consolation prize of member-at-large. I was nominated for member-at-large, which, of course, I won. I said, "Okay. Well, maybe later on."

As member-at-large, I didn't have any real responsibilities. I was on the Council, and I certainly learned lots about how the Council ran. I also, at that point, became chair of the ACM Standards Committee, which was not something I had really looked for. That was an interesting job in itself, because that involved relating to this whole world of official standards people at ANSI, who had an incredibly different worldview. There were some fights about standards. The main one that I remember was one of the software engineering standards. Basically, the ANSI people said something to the effect of, "Well, the ACM people aren't engineers, so they shouldn't have any real say in this." The people at ANSI who were involved in this whole kind of thing were the people who do things like building codes, so it was a total other world. And I remember the ACM software engineering people were very upset about this, that basically these standards were getting set and they weren't allowed to vote on them. I felt that was really not right, and it certainly wasn't something in ACM's interest, so I was fighting this. I remember Dick Hespos, who was the executive director at the time, and I going down the street to the ANSI headquarters in New York and basically arguing about this sort of thing and getting nowhere, and feeling that we were really in another universe. We didn't win. We never could have won. So I remember that. I don't remember too many of the other issues that came up about standards, but there were some.

NORBERG: Did you have to hustle up reports from the various special interest groups to present to Council when the annual meeting was held?

ABRAHAMS: I guess I got them from the board chairs as vice president, but I don't really remember much of that. It probably was just a formality, anyway. 
NORBERG: When you were member-at-large, did you have to deal with any of the chapters or regional representatives?

ABRAHAMS: No. As a Member-at-large, you basically are your own person. You represent nobody but yourself.

NORBERG: How many members-at-large were there?

ABRAHAMS: I think there were two or three. So it was kind of a cushy job in a way because you don't have any responsibilities.

NORBERG: It's not a consolation prize in the same sense of being elected to Council after you have been president, but it's more of, you know, "We don't want you to do this now, but we want to keep you in the wings." And so they keep making you active. They did that with Denning, too, I think.

ABRAHAMS: Yes.

NORBERG: And then, you know, see what happens in the next administration.

ABRAHAMS: Yes. So anyway, I don't remember, but I had a lot of interaction with the next Executive Committee, which was Adele as president, J.A.N. Lee as vice president... I don't remember who the secretary was.

NORBERG: Frailey was with you.

ABRAHAMS: Yes. I don't remember, I should remember, but I know who was secretary on Adele's EC.

NORBERG: I had a chart developed of those things, but when I took this list off the ACM site, I didn't put two of them together.

ABRAHAMS: Actually, I just might be able to determine that because one of the things I uncovered when I was trying to see what I could locate was the minutes of the last Executive Committee in Adele's administration. Maybe that was David Wood. It probably was.

NORBERG: Wood never comes up again, though, does he?

ABRAHAMS: Wood was secretary in my administration, and also in Adele's. Very smart guy. Not terribly ambitious at ACM, but very devoted. And again, somebody I've stayed personally friendly with for a long time. Another one of these people I still exchange Christmas cards with now. Yes, it must've been Dave Wood. So I didn't have much to do with that Executive Committee.

NORBERG: As the observer aside, what was your impression of that administration? You commented about Brandin and you commented about Denning, and then we're going to get to your vice president before long. 
ABRAHAMS: My impression was that Adele did a very good job. She's extremely energetic and very smart and very charming. I really had very little to criticize about how she did that. I guess if you look at my history of ACM, that has to be one of the quiet periods where the biggest thing was probably the Standards Committee and me. I don't remember an awful lot of the stories about that, except that there were some controversial issues.

NORBERG: Did they ever get resolved, to your knowledge?

ABRAHAMS: Since I don't remember what they were, I can't tell you if they got resolved.

NORBERG: All right. Then?

ABRAHAMS: Then came the next election.

NORBERG: That's right. I was just going to turn to the next election.

ABRAHAMS: That was also a ten-dollar story.

NORBERG: [Laughs] Well, give me the ten-dollar story. See if we can make it twenty.

ABRAHAMS: Yep. I felt it was my turn. The presidency was something I could do. Adele had had her turn. She wasn't going to run again. Nobody ever does, though people, including me, have had that thought. I'll tell you more about that later, too. But anyway, I was not to be nominated.

NORBERG: Who was?

ABRAHAMS: Seymour Wolfson and Michael Harrison, as I remember. There were two people who wanted to be president who were not nominated: me and J.A.N. Lee. So this time, we had a four-way election with two petition candidates. [Laughs]

NORBERG: Very democratic organization. Do you remember the number of ballots cast in any of those elections that you were a participant in? Not what you got now, but the total number cast.

ABRAHAMS: It was about 8,000, I think.

NORBERG: Yes, I thought so. At a time when the membership was approaching 40,000, but that--

ABRAHAMS: Yes, but that's typical of organizations.

NORBERG: Yes.

ABRAHAMS: Ever since that, I've really looked at organizations I belong to. What happens in the elections? Often, they have Boards of Directors with 40 people running. How do you 
choose? I mean, how do you even get to look at all the statements? I'm still not sure exactly what determines who people vote for, but there's no way they can know who's competent. The only way you can know who's competent is to really have been very involved, and most people aren't. So there's, first of all, selection by who even bothers to vote, among the voters who know anything. But again, my talent for writing election statements came to my rescue, and I won.

NORBERG: Do you recall who was on the Nominating Committee at that time?

ABRAHAMS: No, I don't. What I do remember in Adele's administration was that she and J.A.N. Lee were at odds. She was very unhappy with J.A.N. Lee. Actually, he wrote a pretty weak statement, I thought, in the presidential election. The first thing that struck me was, I don't remember exactly what the sentence was, but the very first sentence in his election statement was in the passive voice. You don't do that if you want to win. I learned a lot about writing statements from Denning, who wrote superb statements. And an important thing is you always talk in the active voice. I mean, you don't want to come across as arrogant, but you do want to come across as confident, and there are words that have the right connotations and all kinds of things like that. So I won that election. Dick Hespos was the executive director at the time. People called to congratulate me. One of the people who called me was Adele Goldberg, and she said, "You didn't deserve to be elected. Mike Harrison did." You can imagine what happened in the next two years. [Laughter]

Now, as I said, I really was not critical of Adele's presidency. In fact, as well as I can remember, she did very well. But when I was elected, of course, she knew everything and I knew nothing. She had been doing this stuff for years, and I had my one experience as vice president, and that was two years old. She knew how everything worked. So, the very first Executive Committee meeting was held at someplace near the UN building. I still remember that. And she basically was just running roughshod over me. I was almost defenseless. It was very embarrassing for me. People felt sorry for me because she just kept challenging me and insisting on things. I had no experience with this. I didn't know how to deal with it at all. She kept giving me a hard time throughout my entire presidency. The funny thing was that until the Brandin Executive Committee, I had known Adele for a fairly long time and we were on good times. I never fully understood why she turned on me, although I think it had to do with, somehow, the fact that I was the odd man out in the Brandin Executive Committee. And she probably felt that I was just dead weight on that committee. So that's probably what got it started.

Anyway, the one thing that happened at the Executive Committee meeting also, that first disastrous Executive Committee meeting, was that I got a lot of sympathy. You know, I went home and I thought about all of this, and I decided, "Well, I have to have a counterstrategy." The counterstrategy, basically, was to give her enough rope to hang herself. I was very fortunate. My Executive Committee was me, David Wood, and Dennis Frailey. And the three of us got along fine. We didn't agree on everything, but we had very friendly, cordial meetings. It was a superb Executive Committee. I was very happy with it.

NORBERG: It was not an Extended Executive Committee at that time?

ABRAHAMS: There was also an Extended, which included Adele and Jack Esbin. Half the time, Adele didn't bother showing up to that, but Jack, who was treasurer, also was very friendly with me. Our friendship went back to the SIG Board days. In my first election, I won against 
him, but he didn't take it in a hostile way at all. I mean, this whole thing is a story that-- you know, you probably never heard any of this. It was quite an experience for me. But gradually, I started to learn more and more. Adele, I think, kind of got disgusted and became less and less active. I decided that the thing to do was to treat her with the utmost courtesy and respect. Basically, that was my counterstrategy. So if she's going to be a bitch about it, let the world see that. And the best way to show that up is to be really nice, so that's what I did. And it worked. Basically, I got a lot of sympathy and I got a lot of people on my side because I did not respond in kind. I responded in exactly the opposite way. I didn't roll over and play dead, but I just was very courteous. Nobody could say that I was disrespecting her or anything like that. And of course, as the term went on, I learned more and more and got better and better at doing what I was doing.

This brings up something else I wanted to show you. Actually, you might even want to take out a couple of minutes to read it. This should not go into the notes, but it'll probably give you a lot of perspective. Why don't you just take out a couple of minutes and read it because the cover letter tells you what it is.

[The document is a letter to future presidents of ACM. Abrahams had set up a binder, for the use of future presidents only, on "How to be President of ACM", and this was his contribution. Future presidents were invited to add their own contributions, and the binder was supposed to be passed on from each president to his or her successor, and kept confidential.]

[Break]

NORBERG: We were talking about advice to successive presidents by the past president, and there are a number of items in this sort of thinking that we need to explore as we explore the presidency over a couple of years. But I need to do one more thing that I neglected to do when we were talking about the vice presidency, and that is I looked in the ACM forum, and there was a letter from our friend, Herb Grosch. He was complaining about the ACM elections and the integrity of ACM as a result of that. He talked some about Brandin, and I've already asked Dave about those, but what I want to call to your attention to is something that Grosch said, but in a different context, and that is, "The written and highly formal procedures for nominations and elections, which headquarters and the offices and Council permitted Paul Abrahams to violate, also required the Nominating Committee to present two candidates for each position to be filled. The headquarters notified Council and others of the names by November $5^{\text {th }}$," and then he goes on and on to say that this is too tight a schedule. He thinks that because of your violations-it got to be plural, not singular - the Nominating Committee should be discharged for incompetence. Do you remember this?

ABRAHAMS: No, I don't, but it sounds typical of Herb Grosch. And that's right, he was also a buddy of Kathleen Wagner.

NORBERG: Well, Dave's response is just wonderful: "Woe is me." [Laughter] Okay. But that's what you were telling me about, isn't it?

ABRAHAMS: Yes, that is.

NORBERG: The way this group lined up and... 
ABRAHAMS: Herb did not like me.

NORBERG: I don't think he liked too many people.

ABRAHAMS: Yes. Getting back to that binder, the idea was that this was to be seen only by future ACM presidents. Since I wrote it, and created it myself, and that was 20 years ago, I feel like I can talk about it in this interview. I asked Pat to make up this really fancy leather binder to put these in - you know, a binder where you can add things. And the idea was that each president would take it and add their own comments and pass it on to the next one, because I felt there was a lot to learn, especially if this thing accumulated over 20 or 30 years. It would just be invaluable.

NORBERG: It probably would be a great summary of the minutes of meetings, too, when you come right down to it.

ABRAHAMS: Yes. But I don't know what happened to it. I think somebody broke the chain, but I don't know who. I've never heard...

NORBERG: In order to explore this whole idea of what you learned on the job over two years as president, let me ask you a series of questions, which will, I hope, establish your view of what the organization is, what its mission and purpose are, and how these things came about in your mind as you were going through that two-year period. First of all, let me ask, what was ACM's role during the '70s and ' $80 \mathrm{~s}$ ? ACM's role. What did people think was the role? What's in the mission statement? What's in the policies and procedures statement? Somewhere in there, there has to be a comment or some knowledge of what the purpose of the organization was.

ABRAHAMS: Well, I guess there was something in the constitution about what the purpose was. I think of it more in terms of what did ACM do, and what was it for. You know, why did it get established in the first place? I'd have to really think back to what I knew about those early days, which I was not involved in. I just learned about them. What was the need that ACM was fulfilling? I think probably the publications were the big thing, the Communications of the ACM. And there were no other publications initially.

NORBERG: What about the joint computer conferences? And later on, the AFIPS proceedings?

ABRAHAMS: Oh, that happened much later. I was thinking about when ACM was first started. Then it expanded to conferences, and it expanded to educational activities. I guess if I had to say what was ACM's purpose, it was to fulfill the professional responsibilities of computer people towards each other and towards the world. If I had to make something up, that would probably be it.

NORBERG: But yesterday, you commented that the organization was not there to define the role of how the professionals treat each other.

ABRAHAMS: Yes. 
NORBERG: So, how is it serving the members in other ways? You mentioned publications. We could mention this other one that I just raised, about people looking toward the ACM to express their point of view. But are there other roles that you think it was playing in the "70s and in the '80s? And I think those two decades are different.

ABRAHAMS: Well, there were bits and pieces of political activity, like the Sharansky flap. And then there was a lot of interest in knowing Washington-oriented activities. There have been things more recently where ACM has gotten quite involved. Copyright issues-you know, copyright and patents. Privacy issues. Computer security stuff. In fact, the person who's been really the most active in pushing this has been Barbara Simons, again, someone who I've always gotten along very well with and been personally friendly with.

One thing I wrote a President's Letter about was SDI—Reagan's Strategic Defense Initiative, which everyone referred to as Star Wars even though I didn't. I argued that on a technical level it was totally misconceived and couldn't possibly do what it was claimed to be able to do. Dave Parnas was energetically pushing that same argument at the time. I got a lot of criticism for venturing into the political arena, though I tried to argue against SDI only on technical and logical grounds. But I had plenty of supporters on that one.

NORBERG: Okay, so this would mean - to me, anyway — that there was a rather broad statement of mission.

ABRAHAMS: Yes.

NORBERG: Or purpose, either one of those, whichever is right. And all of these other things, as they came up, can be fit into the activities of the organization. Now, that sounds to me as if the organization doesn't really know what it's about.

ABRAHAMS: I can't really dispute it, but I don't think I would agree with that, either. The reason is because I haven't been involved in it so long. But I think what I would do to answer the question is to look at the constitution, which says exactly what ACM's purpose is--

NORBERG: We'll come to that because of one of your presidential letters, which I looked into.

ABRAHAMS: Yes. So, the fact that I can't really tell you now doesn't mean I couldn't show you what the president does.

NORBERG: Of course, yes. We are thinking 25 years in the past. But can we separate out these things - mission, purpose-from functions?

ABRAHAMS: Probably can.

NORBERG: Because several of the things you mentioned sound like functions of the organization-publishing journals and so on. At least in the '70s, until McCracken's term, I don't sense that the organization really had carefully defined these parts of the mission, purpose, and functions of ACM. 
ABRAHAMS: I guess, looking back at it with very cloudy hindsight, I would probably say the purpose of the organization is to do what it was doing.

NORBERG: Mm-hmm [yes]. But that didn't get us anywhere.

ABRAHAMS: Well, if you say that what it was doing was valuable and useful, then it does get you somewhere.

NORBERG: Then I must have some criteria.

ABRAHAMS: Okay. It's to produce publications that are useful to the people in the profession, to run conferences that are useful to people in the profession, to set curricula that are useful to people in the profession, and to explain to the public what computing and computer science are all about. And perhaps they tried to put this all under one umbrella. It's a little bit artificial, but it's what you do because that's what organizations do. An organization finds itself doing six different things, and maybe they're all worthwhile. Maybe this is exactly the way it should be doing it, but it's a hard problem to come up with a common, unifying description of it. It doesn't mean that they're not doing what they should be doing. There's no easy way to describe it.

NORBERG: But our purpose as the interviewers here, in this case, are trying to ascertain what presidents, or even before they became president, what their notion was about the purpose and the mission of the organization.

ABRAHAMS: Well, I could probably reconstruct it by looking at the constitution and some of the things I wrote about it, but I can't remember it now.

NORBERG: All right. I'll come back to it when we get to the place where it might be...

ABRAHAMS: Yes.

NORBERG: Did others have opinions that were different from yours?

ABRAHAMS: About the purpose?

NORBERG: About the purpose and mission. Was this fought out in the Council, for example, during your reign?

ABRAHAMS: The main thing that was fought out was the political stuff. You know, how active should ACM be? And there were also questions about-- I mean, in one sense, it was being fought over all the time, and then the question is, how do you allocate your money? So, you might have several purposes, but some are more important than others, and the more important ones get the money. That was fought over all the time.

NORBERG: In her final presidential letter, Adele Goldberg made some suggestions for the next president.

ABRAHAMS: She didn't know it would be me at that point. [Laughter] 
NORBERG: Oh, why not? She must have. This is in her last letter. Final presidential letter.

ABRAHAMS: But when her letter actually went to the press versus, you know, when did...?

NORBERG: I see.

ABRAHAMS: I don't know if she knew that or not, but I think she probably wouldn't have written what she wrote if she knew it would be me.

NORBERG: Why is that?

ABRAHAMS: Well, because she didn't want me to be elected.

NORBERG: Oh, okay. Sure. But in that letter, she's suggesting that the next president devote more time to the US government activities. Copyright issues, patents, that sort of thing.

ABRAHAMS: Which was, I think, right on. I know that ACM got involved with this stuff; I don't remember how much it was with me because there were issues about ACM's tax status, in particular. There was a second kind of issue, which was a divisive thing, not a unifying thing. When you look at who's on each side, you find people associated with ACM on both sides. I mean, you still do. Should there be more secrecy, or less? Should patent protection be stronger or weaker? All of these kinds of issues. It's hard for ACM to take a stand, although it's done some of that anyway, just because there is so much internal division over it. The whole issue of digital rights and protection of music and all those kinds of things, you find people on both sides of that issue, and they are associated with ACM. So it's hard for ACM to take stands when they're so divisive. And then, of course, if you take a stand on one side, the people on the other side say, "That was improper." So it's a very difficult thing to do. Well, ACM has done some of that, anyway.

NORBERG: Yes. A second thing she suggested was better ways to tap the volunteer spirit in ACM members, and I see that as something that she was proposing with new initiatives. Not saying anything against the people who were already volunteering, but need to find more volunteers and help them to run those. Now, I raised the issue of Adele's last letter because it provides the background for your first one. I don't know whether you agree to that or not, but in your first letter to the members during your term as president, you indicated there were three major challenges facing the organization: defining our constituency and how best to serve it, enhancing our external activities, and reshaping the way we manage our affairs. This would fit into anybody's first letter, from McCracken on. Now, to me, that says that the organization has not really grown up. To use one of Frailey's comments, what will ACM be when it grows up? Number one on this list, defining our constituency and how to serve it, has been a consistent problem, seemingly, for ACM for at least a couple of decades.

ABRAHAMS: Probably so. Probably still is. But the question is, is it unique to ACM?

NORBERG: Well, I can't answer this question. I haven't looked at too many organizations. It wouldn't be the case for ACS, certainly, because they had already gone through these throes of 
development and therefore were able to see what was going on and act on it. Several of the smaller organizations that I know about don't get into this arena because there's simply not enough money anyway, and so it's pretty hard to get them into it. So, are there many organizations? I don't know. But when I look over the Washington scene, I begin to see different kinds of organizations really organized to be lobbying the Aeronautical, or whatever the hell it's called now, and CRA, for the computing area. There are others, too, in chemistry and so on. So when you say this is every organization, or this is probably every organization-I don't want to put words in your mouth-I'm not so sure what that says.

ABRAHAMS: Looking back on it, I suppose there are organizations that are looking for money or influence in Washington. And you can say the ACS is a lot about that. Then there are ones, basically, that are publishing outfits, like the American Math Association or Society-I forget. There were two.

NORBERG: Sure.

ABRAHAMS: Basically, they're in the publishing business. And they also run conferences, I suppose. And that was what ACM was for a long time, it was in the publishing business, in a kind of nonprofit way. Plus, as a side angle, the credentialing business.

NORBERG: Yes, I want to come to that too, because that's an important element in here. Thinking about this first item that you talked about, was this exacerbated by the increase in the number of practitioners versus the researchers?

ABRAHAMS: Yes.

NORBERG: And that had been going on for a decade or more.

ABRAHAMS: Yep. I was generally pretty attuned to the practitioners, even though I had an academic background. But even with my academic background, basically, like I said, I was much more of a programmer than a researcher. My big accomplishments had to do with writing programs that were very difficult to write. You know, PL/I compilers and... I didn't think I mentioned this, but the main reason I picked PL/I was the feeling that if you could compile PL/I, you could compile anything. So it was a big challenge. It was a very difficult language to deal with. I forget where I was.

NORBERG: We're still talking about your major initiatives when you started being president. We talked about the number one on this list, defining a constituency. But if we look back to Adele Goldberg's last presidential letter, which I just quoted for you, or a little bit of it anyway, the issues she thought were left from her administration of ACM are the same as those from yours, from Denning's, from Brandin's, and later on, Bryan Kocher. In fact, Kocher's first letter is almost an indictment of what wasn't accomplished in the previous decade.

ABRAHAMS: But he didn't do much, either. [Laughter] Got himself into trouble.

NORBERG: Okay, but you're sitting there as past president. What did you think about this? About his essentially indicting your administration? 
ABRAHAMS: That didn't really bother me too much, as well as I can remember. He very nearly got impeached.

NORBERG: Is that right?

ABRAHAMS: Yes. Or whatever it was that we did for impeachment. Let's get to the Kocher administration later on.

One of the things in my how-to-be-president-of-ACM thing was the relationship between the president and the past presidents, and I felt that not only was Adele doing me a disservice by her attitude; she was doing ACM a disservice because if she cared about ACM, she should've wanted me to be a good president, an effective president. And I was determined, even though I was opposed to Kocher and I felt he shouldn't have been elected, I nevertheless felt that it was my obligation as past president not necessarily to support his particular initiatives or policies, but at least to support him in his role as president. To avoid, at all costs, doing what Adele had done to me.

NORBERG: That certainly makes sense.

ABRAHAMS: And it was not because I felt I owed him anything. I owed it to ACM.

NORBERG: Yes. Managing the organization became very difficult in these years, partly because the money that came out of the National Computer Conference was no longer available, and partly because AFIPS wasn't doing anything to replace that income.

ABRAHAMS: They couldn't.

NORBERG: Ultimately, it couldn't, and disappeared from the scene.

ABRAHAMS: Yes.

NORBERG: Now, I remember one of your presidential letters about the dynamic system that ACM was. Maybe still is. And you're describing the various points at which certain problems had to be taken care of. One of those was the loss of the National Computer Conference money, and that had to be made up the only way the organization could make it up, was in dues increases and maybe services that you could charge for. When AFIPS went out of business, there was never going to be any more of that money, and yet, more money was needed in order to meet the obligations of the organization. So, a Long-Range Planning Committee was established. Did you establish that Long-Range Planning Committee?

ABRAHAMS: I don't remember. I think Adele claimed to have. I thought I saw something about that.

NORBERG: Well, she named one, that's true, but it was ad hoc. When you got their report, then you went about naming an official one, or getting the organization to name an official one that could handle various problems as they came up-space and money and all those sorts of things they could give some decent advice on. 
ABRAHAMS: Sounds like a good thing to do, but I don't remember that. I suppose that setting up long-range planning committees was one of my favorite activities. [Laughs]

NORBERG: Do you remember what some of the major issues you proposed were at the time?

ABRAHAMS: Well, I remember that ACM was having financial problems at the time, and I guess that one of the biggest priorities of my administration was not going broke. You know, just how do we stay afloat? And when you're dealing with that kind of thing, that doesn't leave a lot of room to deal with a lot of other things. So, in fact, looking back, I was trying to think, well, what would Adele and lots of people do? Try to do one thing, maybe two, and leave it at that. And I think my biggest accomplishments probably were not entirely visible, which had to do with reconstructing the accounting and the way the money flowed within the organization.

NORBERG: That certainly comes through in your report on ACM in early 1988 and the number of, say, paragraphs that were devoted to the issue of money. You appointed a Facilities Planning Committee, for example.

ABRAHAMS: Yes.

NORBERG: And you looked at the NCC agreement and understood that it was detrimental to ACM to continue because it might become responsible for NCC's losses. Had that been handled before in Adele's term?

ABRAHAMS: I don't think it was a problem because the whole NCC thing started to go broke around the time I came into office. I still remember going to an NCC in Chicago.

\section{Session 2, Tape 2, Side A}

ABRAHAMS: It was embarrassing that there was a large auditorium with only about 100 people in it. The attendance was so miserable.

NORBERG: This attendance at the ACM Council meeting.

ABRAHAMS: No, no. This was at the NCC in Chicago.

NORBERG: Oh, yes.

ABRAHAMS: That's when it really stopped being a cash cow. I don't know what the animal is that sucks energy, but... [Laughter] whatever that animal is, AFIPS was that. It had been a cash cow for a whole bunch of people. I don't know at what point you want to talk about AFIPS.

NORBERG: Might as well right now since we've come up to the beginning of your term.

ABRAHAMS: Yes. You can almost talk about AFIPS almost independently of me, and just what was going on there. AFIPS had been running these-- originally, there were the Fall and 
Spring Joint Computer Conferences, and then it turned into NCC something or other. I don't remember exactly what the name of the conference was. But these were big moneymakers. The biggest part of the money came from exhibits. So this was a very nice thing to have on one's balance sheet - not just for ACM, but for DPMA and the Computer Society, and all of these other smaller organizations that were members of this. There were agreements about how this marvelous cash flow got divided up. And then all of a sudden, it started to run dry. Part of the reason, I think, was the rise of COMDEX, and suddenly, NCC wasn't getting the exhibits anymore. What had been a surplus was turning into a big deficit.

Now, there was a certain amount of resentment about how AFIPS worked just because the meetings of the Board of Directors were very luxurious affairs. It was really quite a boondoggle, which I never got in on because the thing started to run dry just as I became president. As president, I was an AFIPS director. Basically, at that point, the question was how do we wind this thing down? There were a lot of conflicts about how to divvy up what was left. AFIPS had this grand headquarters in Washington; the building was being sold. They tried to keep it alive for a while, as I remember, but there was just no resuscitating it. It was pork barrel politics at its finest, I would say. People were in it for the money and nothing else. It did nothing intellectual, as far as I can remember. I remember there were questions about how and when to dissolve it, and what did you do with it, what was left, and even what did you do with the history archives. There was some question about that, which I don't remember the details of. You might know more about that than I do.

NORBERG: Well, actually, I don't. We did not get the AFIPS papers. I don't know where they went.

ABRAHAMS: I remember there was a discussion about that, but I don't remember what the outcomes of it were. So anyway, I think AFIPS was still alive when my term ended, because otherwise I wouldn't have written what I wrote in my advice. I may have continued as an AFIPS director after that; I don't remember. But AFIPS relationships were a big thing for ACM, and then they became not a big thing. And, of course, now there isn't any AFIPS. But that budgetary hole was something that really affected ACM very deeply, and ACM had to adjust. That was probably the biggest single issue I had to deal with: basically, how do we contract? How do we fill the gap or do something? How do we cope with this? And, of course, that was not the kind of thing that leaves a nice historical legacy.

NORBERG: No, it doesn't. [Laughter]

ABRAHAMS: I remember going to a few AFIPS Board meetings, and then being in their headquarters in Washington, which, as I said, got sold. I don't remember anything terribly nice happening at those.

NORBERG: You didn't have any say yourself about what should be done, did you?

ABRAHAMS: Well, I did as the leader of the ACM delegation. ACM, DPMA, and IEEE Computer Society would basically each have three directors, and then the little guys had one each, as I remember. There may even be some further gerrymandering in there. I do remember the vote to dissolve was not straightforward. Not everybody voted for it. There were still a few people who felt some kind of AFIPS could survive, and even at some point, I guess, it had a bit 
of an intellectual legacy. I don't think it was very much, but I think they evolved in computer history. Maybe they even somehow were an ancestor to the Babbage Institute, or something like that.

NORBERG: They were.

ABRAHAMS: Yes. Maybe that's how the Babbage Institute got going.

NORBERG: In part, it became an organization with corporate money and individuals' money, and with some of the money from AFIPS. AFIPS committed themselves, as I remember, to five years at $\$ 50,000$ a year. You suggested to the succeeding president that he not spend much of his time on AFIPS, if any, because it's essentially moribund.

ABRAHAMS: Yes.

NORBERG: Did you hear any more about it as past president?

ABRAHAMS: I guess at that point it was just about dissolving. There wasn't anything left. There may have been some questions about how to pick up the pieces and distribute what was available to distribute.

NORBERG: Did they have any debt, to your knowledge?

ABRAHAMS: I don't think so. I think they ended up with a positive, but not by much. They had the headquarters building, which was, I think, a considerable asset at that point to dispose of.

NORBERG: I was in that building a couple of times. Really pretty nice, actually.

ABRAHAMS: Oh, it was very nice.

NORBERG: Out in the middle of nowhere, but...

ABRAHAMS: In Reston?

NORBERG: Yes. Is that all you have to say about AFIPS?

ABRAHAMS: That's all I can think of at the moment. It just changed character. Even as I was president, it had already started, and then the decay was pretty rapid while I was president. And it was not something I had much control over. Basically, things were in the hands of the conference managers, which was a commercial business, really. There are people who know about that sort of thing, and I wasn't one of them.

NORBERG: I only know from it being a visitor.

ABRAHAMS: One thing I should mention. AFIPS was the American representative to IFIP [International Federation for Information Processing], so when AFIPS went away there was a gap in the American representation at IFIP. I don't remember what was done about that, but I 
believe that ACM and the IEEE Computer society got together somehow to provide the American representation.

NORBERG: Let me ask you about some of the relations inside ACM, among these people on the staff: Pat Ryan, Dick Hespos...

ABRAHAMS: Oh, yes.

NORBERG: During your tenure as president, what units played a special role in advancing the field and profession?

ABRAHAMS: ACM does not do research. Never did. The most that ACM could ever do would be as a facilitator. Even the SIGs don't do research. They run conferences and they publish papers. So, it's a really hard question to answer. I just don't know how to answer it. You know, what did they do to advance the profession? They made things possible, is perhaps the...

NORBERG: Can you be more specific about that, though? If you go back to some of the SIG conversation we had yesterday, you talked about the graphics group, you talked about the design automation group, you talked about the AI group, and so on. I get the impression from what you said that none of these were stimulated by ACM or ACM Council, but that they came out of the grassroots of the individual special interest groups.

ABRAHAMS: I would say so. In fact, there was a strong feeling that the SIGs were ACM's lifeblood, that that's really where the intellectual or professional things were really happening. The chapters were kind of more of a social thing and maybe disseminating information.

NORBERG: But the Council and the SIG Board, for example, were approaching the evaluation of these groups in terms of their viability, number of members, the weight of some of their programs, and so on. So this is an area in which it really is seeing-to-something in the transmission of information from one group to another. Now, I believe you said yesterday that the graphics was the biggest one.

ABRAHAMS: Oh, yes. SIGGRAPH, in particular, was a huge success. I imagine that the things that were presented there were probably very important to the graphics field. SIGPLAN had OOPSLA, which, again, didn't do research, obviously. It was a forum where people who were doing this kind of thing could congregate, talk to each other, and publish.

NORBERG: But if the organization is doing the evaluations of these groups on a yearly basis, then how was it trying to skew the organization one way or the other to make it more equal, so to speak? I mean, you can't collect a thousand people at a DPMA meeting, probably, but you can certainly get a pretty good-sized group within some of these large SIGs. Was the presidential office, was the Council doing anything to promote these things?

ABRAHAMS: That all happened within the SIG Board. Basically, people would come, and there was the birth and the death of a SIG. The birth was a group of people who approached the SIG Board with a proposal to establish a special interest group, and such and such started 
probably as a Special Interest Committee. And then the SIG Board would say-- I don't remember how the finances worked, but the SIG Board somehow managed to drum up some money to help them or they would expect to do it themselves. I don't remember that part of it. As far as I can remember, the SIG Board, until after my time, never really had any money of its own. It was more active as a traffic director to the money that was within the SIGs. And the viability reviews were all within the SIG Board. They may have required Council approval to dissolve a SIG, I don't remember for sure about that. But certainly the administration and the judgment of whether SIGs were viable or not happened within the SIG Board. The viability reviews were more or less run by the area directors. There were five of them, I think, and each one had some number of SIGs under their umbrella. And then if a SIG viability was in question, the SIG Board would vote on what to do about it except possibly - and I don't even think it went that far-for confirming the dissolution of a SIG. And none of this happened at any level above the SIG Board. The Council was not involved.

NORBERG: There were some times that the Council was involved, but that's because the people at the presidential level, like Jean Sammet, felt very strongly about the issues. Was there any, shall I say, envy among the various special interest groups because if there's a large amount at one party, then the other party gets almost nothing?

ABRAHAMS: Yes, there was.

NORBERG: How did this express itself?

ABRAHAMS: Probably kind of subtly, I would guess. As I well I can remember it, people wouldn't come out and just say it. But there certainly was a realization there were rich SIGs and poor SIGs, and then there were questions about how much cross-subsidy should there be. And of course, the poor SIGs thought a lot. There were SIGs that were a little skeptical. And then the rich SIGs were SIGPLAN, SIGDA, and SIGGRAPH, as I remember. And there were a lot of poor ones. And there were some in the middle.

NORBERG: Why keep the poor ones? If they're not doing much, if they're not able to succeed in improving their programs to the point where people would be interested in them, why not just cut them out of the pie?

ABRAHAMS: Because they were small fields, that's why. It wasn't that they were not worthwhile. They just weren't popular, or popular enough.

NORBERG: You didn't mention operating systems, and I would think that would be fairly popular.

ABRAHAMS: In fact, that was the one where Peter Denning came from, SIGOS. I don't remember too much about that one specifically, but that was kind of in the middle. It was one of the ones that were doing okay. It was not in trouble, but it wasn't terribly rich either because they didn't run the kind of big conferences that the rich ones did. That's where the money came from. Any time that ACM had a really good revenue source it was conferences of one kind or another, and even there, you could go a little deeper and say, "Why were the conferences making money?" Well, it wasn't attendance fees. It was exhibit fees. When you look at where it all 
ultimately came from, it was exhibits. And so the people who tended to get rich were the ones who had moneymaking things that could be exhibited. And there may have been one or two intermediate stages to this, but that's ultimately what was going on.

NORBERG: Okay. That clarifies things very nicely. I hadn't been thinking about exhibits at those--

ABRAHAMS: In fact, academic people rarely do. [Laughter] It's so commercial, it's so crass!

NORBERG: Well, but I could see inviting people in to show their wares. At some of the societies that I belong to, it was always book exhibits and not paraphernalia.

ABRAHAMS: Yes, but they don’t pay big money for those fancy books.

NORBERG: And in fact, I would say that they don't pay any money to come and exhibit at all except for the room that they're in, and they just pay for that. The societies don't; they're too small.

ABRAHAMS: Perhaps an interesting sideline in all of this is that you ask, well, what does it take to do this sort of stuff? You know, to be an officer in an organization? And by and large, what it takes are very different things than what it takes to do research. Not entirely, especially as research has become a more corporatized thing. You become more of a manager than an intellectual. I mean, that's a recent development. So people in ACM, especially presidents, you look where did they come from and what sort of managerial background did they have? Some had a lot, some had none. Adele had a great deal. Dan had very little. Jean, I guess, didn't have much. Even though she worked at IBM, she didn't have a lot of that kind of background. You can kind of go through the list and think of who had that sort of background. Peter Denning didn't. He never ran anything much. So, basically, you had people who were doing it by their intuition and smarts and not by their experience, but there were exceptions.

NORBERG: That then should suggest the role for the people in the staff headquarters.

ABRAHAMS: Oh, yes.

NORBERG: That they could be helping these people with finances, advice about finances, and various other kinds of advice to make sure that the conferences were well done. Was that going on?

ABRAHAMS: Oh, yes. Headquarters had a support staff that worked on that kind of thing.

NORBERG: How big was that support staff? Do you remember?

ABRAHAMS: I don't remember. I guess it was about five or six people. But they definitely did have a support function there.

NORBERG: How did the directors of the headquarters office play in the organization? 
ABRAHAMS: Well, the typical tenure of an executive director, I guess, was about ten years. I think Sidney Weinstein had been there about that long. Don Madden, whom I didn't know at all, was there before him. I think it was in Adele's administration that Sidney left and Dick Hespos came in. After Dick Hespos came Joe DeBlasi, who had been at IBM as some kind of executive. And then the next one, who I guess is still executive director, is John White. And that was a total breaking of a pattern because John White had been an ACM president. That's happened in some other organizations. It was the first time it happened in ACM that an officer of the organization eventually became its executive director.

NORBERG: What was your interaction with whoever was in your term? That was Hespos right?

ABRAHAMS: Hespos, yes.

NORBERG: Tell me about him and how you interacted with him.

ABRAHAMS: Generally, I got along with him pretty well. I do remember that very shortly after I knew I had won the election, I decided it was a very good idea to spend some time with him. He lived down in Westport at the time.

NORBERG: Westport, Connecticut?

ABRAHAMS: Westport, Connecticut. And so he basically invited me down for an afternoon and we went out on his boat, which was very pleasant. We kind of schmoozed for a while and then started getting down to business. I don't remember what business we got down to, but I remember--

NORBERG: Was it just the two of you?

ABRAHAMS: Just the two of us, yes. And that's a very important relationship between the president and the executive director, because the staff controls an awful lot. In theory, they don't really set policy and practice, but in practice they often do. It's the executive director who tells the president that he's been elected.

NORBERG: Can you give some examples of how this person, Hespos or whoever else, does influence the Council members or the Executive Committee in particular? Is he always at the Executive Committee meetings?

ABRAHAMS: Yes, he is. His influence is probably kind of subtle. I can't really remember anything specific, but he just offered opinions. Typically, those opinions get listened to. Maybe not always followed, but at least people pay attention to them. And then they will talk about the implications of things, and if you do this, then that will happen. So they are advisers in that sense. Sort of technical advisers. They do all the actual running of the organization. They're the ones who handle membership and everything like that, and they propose programs from time to time. In fact, that was one of the things that headquarters would ask for a budget to do this and to do that. Whether they thought it was worthwhile to do this or to do that. It's kind of like in England. You know, civil service. And if you compare it with the British Civil Service, I 
think you can get a pretty good insight. They're there all the time. The presidents come and go, especially since no president is around for more than two years. Executive directors and people like that stay around for far longer. And just because of their longevity, they wield a great deal of influence.

NORBERG: Can you speak of any of the other people in the office?

ABRAHAMS: Headquarters?

NORBERG: Yes. You've mentioned Pat Ryan two or three times now.

ABRAHAMS: Pat Ryan was very, very competent, very skilled. I don't think she had a lot of education, and sometimes that showed up, so she's one of these people who really pulled herself up by her bootstraps as far as I can tell. I don't know what role she plays now, but she kept moving up in the organization.

NORBERG: She's operating officer, I think is what it's called.

ABRAHAMS: Yes, that would make sense. I remember she and John White got along extremely well. They were real buddy-buddy, and that was a good thing. She was able to be more effective because of that, and so was he, as I remember, when he was president. I guess he was president after Kocher, if I remember right. Another example of a vice president who went on to become president.

NORBERG: I can tell you that. Yes, he was. '90 to '92.

ABRAHAMS: Yes. So I had a lot of interaction with headquarters people. I remember there were issues about headquarters' computer facilities, too, that I got involved in.

NORBERG: Was that during your presidential years, or was that during Brandin's presidential years?

ABRAHAMS: I think that was during the presidential years that I got involved in some of the issues. There were always issues about how headquarters did computing, which was kind of ironic in a way, you know, that an organization like that did not have particularly good computing for itself.

NORBERG: It's a question of money, not a question of desire, I think.

ABRAHAMS: Well, it was also a question of having the right people at headquarters who knew about that stuff.

NORBERG: During your years, the membership was 77,000 .

ABRAHAMS: Sounds about right. I don't remember whether it went up, down, or what, but it didn't change dramatically. 
NORBERG: That was the peak during the ' 80 s. In ' 87 , it dropped to 72,000 , so this is a considerably loss, but that could be associated with change in dues.

\section{ABRAHAMS: Yes.}

NORBERG: And then in '88, it dropped just a little more, but only by a couple of thousand. This is from your annual report in 1988 that I'm looking at. What I wanted to find out here is it seems to me that you talk about the headquarters' materials and the necessity to improve the automation or computing within the organization so they could do a better job for everybody.

ABRAHAMS: Yes.

NORBERG: But it's not easy to find in that. Did that organization, the ACM headquarters, actually oversee publication activities? Or was that given in to somebody else?

ABRAHAMS: Well, they had, and I guess still have an office that handles a lot of that stuff. In fact, a lot of the stuff with Communications was actually done in headquarters. Peter Denning pushed to have even more of it done there. I remember Mark Mandelbaum, I think, was the person in charge when I was there. Don't remember exactly what he did, but they certainly handled all the mechanics of it, of getting journals and things out. You know, talked to the printers and that kind of thing.

NORBERG: All right. That's what I was trying to find out.

ABRAHAMS: At least, they did that. They may have done more than that, in particular, with Communications.

NORBERG: When you look at Communications in the late ' 80 s, you see a lot of political descriptions and you see some practical advice for programmers. Some of the controversial issues that the society had to deal with. I think in moving on in this discussion, I've jumped around a little bit, but only in response to your responses. So maybe it would be a good idea-Why don't we reconvene to have you review some of these issues as you became president and what happened? Which ones did you think were the most important, which ones you thought were a pain in the neck and didn't want to really deal with anyway, and which did you give over to Frailey? Okay? Good. [Break]

We've just had a break for lunch and are resuming our conversation about the presidential years of Dr. Paul Abrahams. Now, I asked you at one point, and we got sort of sidetracked, I think, from it, what some of the major initiatives that you proposed in those early years. Some of that's in the presidential letters, but do you remember them? And can you describe what happened?

ABRAHAMS: The only thing I really remember well was some of the financial issues. In a way, I think that's one of the things I contributed, even though it wasn't very apparent to the membership. But there was some funny business going on in the way ACM did its accounting. Peter Denning also got involved in that. I remember him delivering a sermon about accrual accounting - or "cruel accounting" as he jokingly referred to it. [Laughter] 
NORBERG: This was during his term, I take it.

ABRAHAMS: His term, yes. The big issue I was interested in was the accounting of the revenues from CACM and membership dues. The Publications Board kept boasting that they were running huge surpluses that they were returning to ACM. Where did they come from? They came from membership dues. And so why should the Publications Board get them in the first place? I looked into the whole issue of that, and I decided the accounting was more than a little bit flaky, and that it affected how our resources got allocated within ACM-in particular, whether the Publications Board had control over them or not. So I pushed, successfully, to recast the way that that particular bit of accounting was done. Basically, instead of the membership money going directly to the Publications Board, or some part of it. As I remember, it went to headquarters, it was counted as entire organization revenue, and then basically, putting out Communications was a cost. When I say it went to the organization, it got distributed in the budgets and everything else, so there was nothing wrong with that. And then they figured out, you know, what were the costs of publishing CACM? That's what the Pubs Board got reimbursed for, what it actually cost to publish it. And actually, I guess a lot of that even didn't go to the Pubs Board, it went to headquarters because they were the ones who did the printing and the distribution and all that kind of stuff...

NORBERG: Well, if they were using the accrual system, how did they identify monies that had to be spent over a fiscal year because of the way dues are collected and the way the expenses of the publications are handled?

ABRAHAMS: As I remember, the idea was that when you collect dues, you don't book all the revenue directly right away. You book it over a period of years because membership service is rendered over a period of years. What the numbers were, I don't remember.

NORBERG: That's all right. I've only seen one budget, anyway.

ABRAHAMS: Yes. So much of ACM's administrative energy went into the budget. There were other accounting issues, too, that I looked at, but I don't remember any more for sure what they were. I remember getting very involved in the overhead. That was a big one, how overhead got accounted for. The reason this wasn't just nitpicking was because, ultimately, the way the accounting is done determines how money is allocated, therefore determines which things are more likely to happen than which other things. So it wasn't just an administrative issue. There were real policy implications behind it, and I felt that it was not being handled in a very straightforward way. I worked fairly hard on getting it straightened out, and I remember even running a little tutorial session on the subject of how the accounting worked and some of the odder aspects of it. Peter did the same thing, actually, at one point with the whole idea of introducing accrual accounting. I think before that, they were on a cash accounting basis. If I remember right, he made that change, which was a very wise thing of him to do.

NORBERG: So you would consider this to be a major initiative of yours, to try and get it under control.

ABRAHAMS: Yes, even though it's not very perfect. But then this brings up the other thing: What difference does it make who's president, anyway? This whole interview has led me to 
think about that. If you look at the most effective and least effective presidents, how much difference was there in terms of results between the most effective and the least effective ones? The answer I'm coming to is: not very much.

NORBERG: Well, that's because of the headquarters staff, I would assume.

ABRAHAMS: Yes. It's partly because of the headquarters staff and it's partly the analogy of the captain of the ship. The ship moves in its own ways, you know? You can kind of influence it a little, but it's a very big ship. A lot happens from the bottom up-so much of the activities, particularly the crucial things in publications and conferences. Conferences, by and large, happen through the SIGs. Not all of them. And those are ACM's probably most visible activities. Those things kind of go on independently of what a president does. I mean, a president may suggest another conference or get rid of a conference or something like that, but these were kind of bumps on a log, in a way. I think the best thing that a president can contribute - and it's really something you only contribute over two years - is to keep things running smoothly, just like the captain of a ship, and maybe to make some incremental improvements. What did Adele do? Looking at it 20 years later, what did she accomplish? What did David accomplish? You can ask the same question about any president.

NORBERG: I'm asking it of you, too.

ABRAHAMS: Yes. And I think the answer is, I kept the ship moving and made a few improvements in how it moves. I don't think that, ultimately, David or Adele could give a much better answer than that, even though they might try to. Despite the fact that Adele really treated me terribly, I still think she was extremely competent. I think she had failures in self-perception. I don't think David did, but I think she did because I think if she had been more aware of herself, she would not have tangled with me the way she did.

NORBERG: What would you say are the characteristics that a person must focus on in order to know themselves? We're not talking about the Ten Commandments, I assume. We're talking about something else.

ABRAHAMS: Know what you're good at. Know what you're not good at. When you get something wrong, recognize it and don't keep defending it-move on. Recognize the things you should and should not be trying to do because of your own limitations or capabilities.

NORBERG: Do you think most people are as reflective as that?

ABRAHAMS: No.

NORBERG: I don't, either.

ABRAHAMS: Maybe that's partly me, but I felt that, in a way, not pursuing lost causes strengthened me enormously. Being able to recognize them: "Well, I've lost that one," and not fight it. And recognize when other people are right and not hang onto that, either, because you can expend an enormous amount of energy fighting for a lost cause. So that energy is energy you could putting in on something else. So much of being effective in a job like the presidency 
consists of not even so much of precisely what you do, but just understanding what's happening, because if you don't understand what's happening, it's very hard to do anything well.

NORBERG: Do you think personal style, though, is different than what you're talking about?

ABRAHAMS: Yes.

NORBERG: Knowing yourself is different than the style that you're operating with.

ABRAHAMS: Oh, yes. Very different, because people who know themselves can have very different styles. Some are schmoozers; others are aloof, for example. Some people are good at certain kinds of thinking and not so good at other kinds of thinking. You learn what your strengths are and what your weaknesses are, and you follow your strengths.

NORBERG: Yes. Well, some people learn too late, I think.

ABRAHAMS: Yes. One way of thinking about "Know thyself" is it's a way of leveraging your strengths to accomplish the most with them. I guess in some ways, 20 years later, I'm a little bit cynical about what presidents do, presidents of ACM, anyway. [Laughter]

NORBERG: All right. Coming back to the major initiatives now, there's one major initiative that you mentioned: getting hold of the finances in a better way. What other things did you try?

ABRAHAMS: I think I did try other things that I talked about in my president's letters in CACM, but I don't remember a lot of the other things I did. There were a lot of probably minor things. There were things I got dragged into. The best example of something I got dragged into-you know, I really got blindsided on that one-was this whole business about the tax status of independent computer consultants.

NORBERG: I don't know anything about that issue. Can you enlighten me?

ABRAHAMS: Yes, I sure can. It turned out that the IRS got on some kind of a crusade about independent contractors. What was an independent contractor? If you were an independent contractor, then you didn't have to pay withholding tax, but if you weren't, then you did have to pay it. Were you really an employee, or were you an independent contractor? And this came up all the time with contract programmers. You know, people who go into these companies and work there for a couple of years as "consultants" but are told what to do every day. But they said they were independent contractors, and the IRS was saying, "No, you're not independent contractors." There were a lot of these guys around, and quite a number of them were members of the ACM. They also were members of IEEE. So they tried to pressure ACM in taking a strong stand that the IRS should change their rules on this. I was not terribly happy with that, although I was under an enormous amount of pressure on the issue from a fairly small, but very, very loud group.

NORBERG: They did not want to have withholding, I take it. 
ABRAHAMS: That's right. They did not want to have withholding. Did not want to be subject to that. They gave all these reasons why they were really independent, and to me, it still was not terribly believable because they went to work every day to the same place for a couple of years and they had bosses there who told them what to do, just like any employee. And to me, that meant they weren't really independent. They didn't set their own hours, for example.

Ultimately, ACM really didn't do much. I think we made some kind of a wishy-washy statement on the subject and left it at that. The consultants weren't terribly happy with that, but I haven't heard about that issue for a long time. But it was a real pain to deal with at the time. I remember it consumed a lot of energy, and not just me, other people, too.

NORBERG: Were there presentations made to the IRS?

ABRAHAMS: Not to the IRS. I don't think we ever actually talked to the IRS, but there were certainly discussions in the Council. Another thing I didn't really get to talk about-- You asked about Robert's Rules. David was a master of that. The thing I realized very, very quickly - in fact, I realized it before I chaired my first Council meeting - was that people are going to use Robert's Rules to try to control what's happening. So, if that's going to be going on, I had better know more about Robert's Rules than anyone else in the room. So I made a point of studying it very, very carefully and really learning and becoming an expert on parliamentary procedure. I virtually never got blindsided by it as a result. I always knew how to handle things like that.

There was also an interesting issue about the parliamentarians. You know, there would be some question about procedures, and so the typical reaction was, "Let's ask the parliamentarian." I realized that this was not proper because the parliamentarian is not supposed to rule on these things; the chair is. So the parliamentarian is an adviser to the chair and whispers off in the corner to the chair about the situation, but never, never directly talks to the body. It took me a while to get that problem straightened out. I think I did pretty well on that. Meetings were still very hard to control. Sometimes you just get blindsided by something, and I remember one meeting that had happened where the thing that blindsided me was the time and place of the next meeting. It seemed like it was almost set. We were about to vote, but somebody said, "Oh, there's a conflict with this meeting," and so we started to try to adjust that. And they said, "Oh, there's a conflict with that meeting." I remember it just became chaotic, and I really lost control of the meeting. I had never expected it. I never thought that this issue of where we meet next would consume so much energy and create so much chaos.

NORBERG: Well, I would have thought that is something you could hand over to the headquarters' office and let them do all this checking.

ABRAHAMS: I don't remember why it didn't happen that way, but it didn't. The other thing I realized in general about scheduling things-- You know, there are times when I felt that I perceived reality and not too many other people did. It may be very arrogant of me, but I'll give you an example, and it has to do with scheduling meetings. Very simple thing. You have a meeting. You have six people in the room. You have to schedule a meeting. When should it be? Well, what most people do is they ask what's okay. You may put up several dates and say, "Do you like this one, or do you like that one?" A much, much better way to do it is, instead of ruling things in, rule them out. In other words, the meeting time is the one that the fewest people object to, not the one that the most people want. But that's typically not how it's done. 


\section{Session 2, Tape 2, Side B}

ABRAHAMS: There were a few things like that, where I felt I just understood how it worked and not too many other people seemed to. So anyway, as far as Robert's Rules went, I think that's how it worked. There were various procedures that were interesting. In retrospect, what's amazing is what people, including me, did not understand, like how to run Council elections. There were a number of elections within Council for things like the treasurer and the Pubs Board chair. The question is, when you have an election with six candidates, how do you organize it? And there was something they called the "Council algorithm." I don't remember exactly what it was, but it involved several rounds of elections if the first outcome wasn't satisfactory. Well, subsequently, I learned more about elections and I learned about the mathematics of elections, which is a whole interesting subject in and of itself, which somebody won the Nobel Prize forKenneth Arrow, who is an economist at the University of Chicago-for proving that, basically, there is no such thing as a perfect election. But you can come close. Some version of preferential voting, like instant run-off. I can go on about that subject forever now.

NORBERG: But you were talking about elections that the Council was holding, rather then the organization. There's a whole big other question about how many times you're going to go to the members for a single thing.

ABRAHAMS: Yes. Well, the only thing you go to the members for is, I guess, not even bylaw changes, but constitutional changes, and there were a couple of them. There was one where we had to go to the members to fix the Certificate of Incorporation. I remember that came up, because it had to do with some of the constitutional changes. There was some little thing that we needed to change. I don't remember what it was, but doing it required changing the Certificate of Incorporation, so that required a membership vote.

NORBERG: That would involve changing the tax status, for example, of the organization.

ABRAHAMS: Or maybe it was changing the name. Something like that.

NORBERG: Yes. There was that during McCracken's term, and it was voted down. As you know, the change did not come about. Now, are you talking about that? Or did this question of name come up again during your term ten years later?

ABRAHAMS: Yes, it did. I don't remember exactly how it all came out, but I do remember there was something-- that may not even have been the issue that we had to go to the membership on, but we did have to get a membership vote for a change to the Certificate of Incorporation. It was not some deep policy issue; it was mechanically very important but not at all controversial. But actually, we were on the subject of Council, I guess.

NORBERG: Yes.

ABRAHAMS: There were a number of things, I think, that involved filling vacancies. Elections took place within Council. Treasurer vacancies, Pubs Board chair, and there were probably a couple of others, too. AFIPS representatives, I think, were elected by Council. So you would 
have nominations, and you might have six people nominated or something like that, so the only question was how we run these elections. The problem is, if you do it by plurality where the person with the most votes wins even if it's less than $50 \%$, you get very distorted results, and we realized that pretty quickly. So you need something else. There was a scheme, basically, for eliminating the candidates who got the least votes, and then voting again. We kind of got along with it, but really, it was possible to do much better. Despite the fact there were lots of very smart people, including people with lots of math background, on the Council, nobody seemed to know about the mathematics of elections. They didn't know that they didn't know. I certainly didn't.

NORBERG: How many people were on the Council at this time.

ABRAHAMS: Twenty-four. It was a big group, which made it also very hard to control the meetings.

NORBERG: Sure. Now, in nominating someone, it doesn't have to be someone associated with the Board, does it?

ABRAHAMS: No.

NORBERG: Okay, so there's somebody outside there.

ABRAHAMS: There may have been some things that came to the Council first, but I don't remember that there were many or any.

NORBERG: People would get to Council as a result of being elected.

ABRAHAMS: Yes. Another thing that looking at that how-to-be-president thing reminded me of was the role of the Publications Board, because it was really a very strong, independent power center. That was particularly the case because Stuart Lynn, who ran it, was a very strong-minded individual. There were two board chairs who were not appointed by the president: One of them was Publications and the other was SIGs. They were both very powerful.

NORBERG: In what sense were they powerful?

ABRAHAMS: They controlled a lot of money, and they also were pretty influential. They controlled how things were done in a major part of the organization. Subsequently, I believe the SIG Board chair was put on the Executive Committee, which I felt was a mistake simply because I felt that the Executive Committee, if it's really to be effective, should be small. It was getting bigger. Even within the Executive Committee, there was-- I guess he was on the Extended Executive Committee, or something like that. It was big enough with five. More than big enough with five. I don't remember what I was getting at there.

NORBERG: I'm trying to see what sort of initiatives you were pushing and what you were facing as president. 
ABRAHAMS: Well, I think the answer to that has to be-- I don't really remember it now, but I'm sure I could have told you at the time. If I went through my president's letters and things like that, I can probably give you a much better answer than I can now.

NORBERG: But we'll come to some of those in a subsequent session. I'm getting the impression from what you're telling that, in fact, the president's major role is to just chair the Council meetings.

ABRAHAMS: I think it's more than that. That is a major role. One of the roles that's very important and I didn't mention at all is appointing the board chairs, because the board chairs, in turn, determined what happened in particular areas. Education. Conferences. External activities. So who you appoint there has a lot to do with what happens. The other thing that actually relates to something else I know you wanted a chance to talk about. I have to quote Theodore Roosevelt: "The presidency is a bully pulpit." I think that a lot of the role of the president is not so much even the particular programs or anything like that, but more to act as a kind of leader, a cheerleader, an inspiration, and a motivator to get people to do things. In that sense, it's very hard to say what you accomplished except that you got other people to accomplish things.

NORBERG: Well, to decide and be a good leader.

ABRAHAMS: Yes. I know one of the things you're interested in is some of the president's letters I wrote that seem kind of off the subject. I was not the first one do that. In fact, Peter Denning wrote quite a few that were off the subject, and that was partly why I felt I could do it, because I saw that he had done it. And not only had he done it, but I felt that he did it extremely well. People liked that. In fact, if nothing else, if I wrote interesting president's letters, then it would make people more interested in reading CACM. The more interesting stuff that is in there, the more people want to read it. And of course, the more people want to read it, the more they'll want to be members of ACM.

NORBERG: Okay. I guess what I was getting at in distinguishing between those, which are organizational issues and those which are not, is to see whether there was anything else behind your thinking at the time. I asked Peter the same question. What was he thinking of that he was going to accomplish under these circumstances? Because that does seem outside the role of the president. And it has a financial implication because it takes up pages within the journal.

ABRAHAMS: What was his answer?

NORBERG: I can't remember now. I think that he went on to talk about his role as editor of CACM after he was finished with the presidency and why the editorials there were important, and then we never got back to the issue.

ABRAHAMS: I felt that as president of ACM, I was also, in a way, a leader of the computing community. So there were things that I felt were important to get across to the community. There were messages that were not just directed to people as ACM members, but as members of the computing community. One of the ones that I was proudest of is perhaps one of the most odd, which was "A Gown for the Princess," which had a subtitle, "A Parable for Software 
Engineers." The idea that was coming across there-- You know, I really enjoyed writing that one. Interesting literary exercise for me. Was that a lot of what's going on in software engineering is crap, basically. [Laughter] It's junk.

NORBERG: It is.

ABRAHAMS: I was very interested in the subject of software engineering and what was going on with it. Why are some people called programmers and other called software engineers? So anyway, the whole idea of that was to do something as a parable. I was really proud of the fact that I could really get across a lesson about computing without once mentioning computers. Cast it as a fairy tale. There are very real issues about how you get software written, and what are the big problems in getting it written and getting it to work.

NORBERG: But sometimes when you're trying to make a case to practitioners in this organization we're talking about here, or other people, like in the general public, you're trying to get across such a thought. Are you really convinced that parables these days work? They might have in $100 \mathrm{BC}$, but...

ABRAHAMS: I don't know. I guess at the time I thought it did, but then maybe part of it all, I have to admit, was just having some fun with it.

NORBERG: There's nothing wrong with having fun.

ABRAHAMS: Yes. I'm not the first president, by the way, to write a humorous president's letter.

NORBERG: Sure. Yes. No, I'm not trying to criticize you. But in three cases, there is no parable involved.

ABRAHAMS: Most of them did. That was all there really was.

NORBERG: "The Role of Failure in Software Design", "What is Computer Science?", "The Pleasures of Programming," and so on. These were fairly straightforward analyses of what was going on in the profession. There was lots of talk about "What is Computer Science?" I remember that in the department I was in at Minnesota. Now, this is a struggle. Chemists don't have to struggle with this. They know what chemistry is. They also know the distinction between chemistry and chemical engineering. So why was this a difficult subject for ACM? You mentioned Peter Denning. He was writing these things for 20 years.

ABRAHAMS: That's right. Remember I mentioned Max Goldstein at NYU? I still remember something he said, which is, anything with "science" in its name is not a science.

NORBERG: Why is that?

ABRAHAMS: He mentioned social science. Computer science. He mentioned a couple of others, to which I added Christian Science. [Laughter] But there's always been this identity question in the field about whether computer science is really just programming putting on airs. 
There's a lot of nervous uncertainty about this still, and some of it has to do with the name. Peter was interested in that issue too, and I still feel that the field is misnamed.

NORBERG: How would you rename it, if you had the authority?

ABRAHAMS: I often say on that that the name that seems, to me, perfectly appropriate and really describes what's going on, that name is "computology." It's the study of computational processes and the means by which they are realized. And that really covers it all. Covers the theory, covers the practice.

NORBERG: That's a long sentence, though, whereas "computer science" is a nice shorthand.

ABRAHAMS: But "computology" is one word. The rest of it is just to explain what it is. How do you define what chemistry is?

NORBERG: You did answer my question. No problem with that. That gets me way ahead of where I am here, so...

ABRAHAMS: Okay. Well, let's go back to where you want to be.

NORBERG: Yes, I think that would be a good idea. The thing that came up in your answers here about what the president does, you mentioned all these various boards and the fact that they need to be managed as a group. Not managed individually, but managed as a group in order to keep a balance within the organization. Do you remember any particular problems with any of those groups? I have a list of them here. Coalition on Diversified Computing, Committee on Women in Computing, Committee on ACM History, Computers and Public Policy, Constitution and Bylaws, $\mathrm{K}$ through 12 Task Force, and so on.

ABRAHAMS: You know, it's funny. I remember virtually nothing about those, but I remember the boards. I don't remember if the committees were under particular boards or directly under the president. Constitution and Bylaws was different from all the others because it dealt with internal administrative issues, not the world outside ACM.

NORBERG: Oh, yes. I didn't look at that, either. But it seemed to me that things like Computers and Public Policy, and Computers and Privacy were freestanding.

ABRAHAMS: They could have been. I think I may have set up a couple of freestanding ones. When you mention public policy, one of the big issues there, which I had mentioned earlier, was this business about the scientific freedom and human rights, which turned out to be, very specifically, the Russian refuseniks. And the question was, how much should ACM be involved in that? There has always been a question of how much should ACM be involved in such issues, both legally and professionally. Are we going to get into trouble with the IRS? It seems that we're probably pretty far from that, but we could, conceivably, at some point. There were all kinds of tax issues that came up. I don't remember specifically what they were, but there were always issues like that, about our tax status as a $501 \mathrm{c}(3)$ nonprofit organization. But on the external thing, there were a number of issues. There was the question of what can we legally do without losing our tax exemptions, and then the other big issue about that was, well, if the 
membership is not unified on the issue, which they virtually never will be, to what extent is it appropriate for ACM to take a stand on something? We can certainly publish studies of things. Nobody can object to that, really. But to actually say, "This is what it should be," will almost invariably antagonize some subgroup of the membership. So that was an issue that I think still continues. There are people who are pretty activist about this sort of thing, like Barbara Simons.

NORBERG: Did ACM ever change its constitutional statement to include public policy issues and the lobbying that goes along with them?

ABRAHAMS: I don't think so. I'm trying to remember if we ever changed the constitution at all. We were forever tinkering with the bylaws. In fact, I think that was one of the things I had forgotten about, but I seem to remember I was involved with some of that tinkering. David Wood was involved even more with it. He did the rewrite of the policies and procedures manual, which was a Herculean task. I got somewhat involved in that, as I remember, but I don't think I got involved in terribly much detail. I really wish I could remember those days better.

NORBERG: Well, that's all right. You're doing very well. I was just thinking how I was going to ask the next question, and it has to do with one of the comments that you made before about the change of an executive director is a golden opportunity.

ABRAHAMS: Yes.

NORBERG: Did that ever take place in your administration?

ABRAHAMS: It took place in Bryan Kocher's administration, when I was past president, so I got involved in it that way, including interviewing candidates for the next one.

NORBERG: Was there a sizeable committee?

ABRAHAMS: The people who did that interviewing, I think, were maybe four or five. I remember Dave Brandin was very involved in that. We had an executive search firm engaged for that sort of thing. That was the kind of process that Dave was very familiar with because of his industrial background. But everything having to do with the executive director was either the president's responsibility directly, or the Executive Committee. The executive director has a lot of power because he's always there. He's a full-time employee, and very few other people are. I guess, as president, I think the typical number was you may devote $70 \%$ or $80 \%$ of your time to it, but not $100 \%$. I don't know that any president ever did devote $100 \%$. They have to make a living.

NORBERG: But were there any problems with trying to name any of these executive directors or staff people?

ABRAHAMS: The Executive Committee had to approve top-level appointments at headquarters. Basically department heads, I guess it was. And their salaries, and their performance reviews. All that went through the Executive Committee. The Executive Committee, entirely on its own, writes the performance review of the Executive Director and sets his salary. 
NORBERG: Do you remember any problems with that?

ABRAHAMS: Not really. There were a couple of changes. I don't remember any big arguments about that, about the individuals.

NORBERG: Was anybody ever offered the position of executive director, and then they--

ABRAHAMS: No. The way it worked was that the search committee or the company or whatever it was basically got a collection of people who wanted the job, brought them in for interviews, and then offered the job to one of them, and the first one accepted.

NORBERG: Who was making the offer?

ABRAHAMS: ACM.

NORBERG: Well, who's that?

ABRAHAMS: Oh. The offer, I believe, came from the executive recruiting outfit. I think they were the ones who actually-- Or it could have been from the chair of the ACM committee on this, which would have been David Brandin. It might have come from David Brandin, it might have come from the recruiters. "Here's what we can offer you. Do you want the job?" That conversation.

NORBERG: I'm curious as to whether anybody was offered it by the committee, and then somehow the Council said, "Whoa, whoa, hold the phone here. We're going to do this differently."

ABRAHAMS: Oh, the Council had to approve it. I forgot that, but that's true. Subsequently, I remember hearing without any details that for the position of the next executive director, the one who replaced Joe DeBlasi, there actually was somebody who was offered the job confidentially and then was rejected by Council.

NORBERG: Do you remember which one it was?

ABRAHAMS: That was the one that ultimately went to John White.

NORBERG: One other thing that you keep talking about is having appropriate and helpful advisers when you're president. Who did you have as your advisers?

ABRAHAMS: I had — and they really did function that way-I had Dave Wood, Dennis Frailey, and Jack Esbin.

NORBERG: But all of those were all officers of one kind or another. 
ABRAHAMS: That's right. That was a problem. I didn't really have any advisers outside of that. In a way, it was very seductive to have them as advisers because of the fact that we got along extremely well. When we had disagreements, they were never personalized. So when I said that I think the president should have independent advisers, that didn't mean that I actually had them. Some other president should have them. Well, it's good if you can have independent advisory, but if you can't find ones you're comfortable with, then you don't have them.

NORBERG: Yesterday we talked a little about financial advisers for the various special interest groups. Did the organization have a financial adviser at the Council level?

ABRAHAMS: You had the Finance Committee, which I guess functioned in that role. I remember there was some controversy about the guy who was running that at one time, Joe Leubitz. I don't remember what the controversy was, but there was some controversy about it. And then at the SIG level, of course, there was Jon Meads, who was also one of the ringleaders of SIGBOOZE. David probably told you lots about SIGBOOZE.

NORBERG: Not so much.

ABRAHAMS: Well, the ringleaders were, as I remember, Dave Brandin; Bob Ashenhurst, who also was a Council parliamentarian and editor of CACM at one point; Jon Meads; Jim Adams, Dave Brandin. I'm trying to remember who else was.

NORBERG: D'Auria was there, wasn't he?

ABRAHAMS: Oh, yeah. Tom D'Auria. That's right.

NORBERG: What did this group do other than just have drinks together?

ABRAHAMS: Well, it hosted a party at every major ACM meeting.

NORBERG: Is that right?

ABRAHAMS: Yes, yes. We would drink, but it was the major social event of ACM Council meetings.

NORBERG: Were you fellows paying for this out of your own pockets?

ABRAHAMS: We contributed to them. I don't remember exactly how-- ACM itself didn't pay anything, I'm pretty sure of that, but I don't remember for sure how it did get paid for. Maybe they charged admission.

NORBERG: Well, that's interesting, having a big party like that.

ABRAHAMS: Yeah. It gave people a chance to meet and get together outside of the formal context of meetings. I haven't seen many other organizations do similar things. I mean, there were also the usual kind of little cocktail parties and things like that, but this was typically in the evenings. It went on very late. In fact, I remember that one of the things that ACM presidents 
do is to act as master of ceremonies for various public events. One of those was the retirement party for Irene Hollister, who I guess was the...I don't remember exactly what her title was at headquarters, but she was in charge of all kinds of policies and procedures and administrative stuff. Kind of proper-looking, proper-sounding lady of I guess mid-60s. If you thought of propriety, you thought of Irene Hollister. So I was making this...you know, the kind of thing you do when you're emceeing something, so I was introducing her and I described all the marvelous things she did, but then I said she has a secret role. And the secret role was to be the bag lady for SIGBOOZE. [Laughter] And how she collected all the dues. Of course, everybody knew Irene. It was like two different worlds.

NORBERG: This organization was reasonably large then, if that's the case. You talk about the five founders, but then if she's collecting dues from other people--

ABRAHAMS: Oh, she had nothing to do with SIGBOOZE in reality. It was all a joke.

NORBERG: All a joke. Okay. I fell for it.

ABRAHAMS: Yes . It would have been the last thing in the world she really would have done, and everybody knew that, so that's why I thought it was a very entertaining joke.

NORBERG: I'm puzzled about both the president's and the Council's position with respect to the naming of board chairs.

ABRAHAMS: That was pretty straightforward. The president named them. I don't think they even had to be confirmed, but I'm not sure about that. But the president definitely named them.

NORBERG: You do not appoint the chair of the Publications Board.

ABRAHAMS: That's right. The two exceptions were the Pubs Board and the SIGs Board.

NORBERG: But who was naming the person who would take care of the Publications Board?

ABRAHAMS: The Council elected the Pubs Board chair.

NORBERG: Okay. Well, that's inside the organization. Okay.

ABRAHAMS: Yes. So its not the membership; it is not the president; it's the Council.

NORBERG: All right, let me shift topics for a bit. Dennis Frailey wrote the 1986 report of the Long-Range Planning Committee in Communications. One of their recommendations was to make the Long-Range Planning Committee permanent. Now, when I read this, I read this as Dennis Frailey's sort of opinion, proposal, and so on. But since this was within your administration, were you in agreement with what he wrote in that piece?

ABRAHAMS: I don't remember that I was, but I probably was because I think that, pretty much-- I'm sure I wasn't in disagreement. I may have been kind of neutral at worst. I probably was in agreement. 
NORBERG: Okay. Let me expand on that, then.

ABRAHAMS: One thing I should say on that subject is I remember that Dennis tended to make matrices of things. He would come up with these presentations on the overhead projector. $\mathrm{He}$ tended to have matrices of this versus that. Some people, as I remember, felt he was being a little overformal about it and that kind of approach didn't work quite so well. I don't remember what was in these matrices; I just remember that they were there. They were a central part of his way of approaching things. I may have actually disagreed with some of the details. I probably did, but I don't think I expressed that. I felt that, basically, this was his thing, his idea. I felt that it was a good idea, even if I might not agree with the details, but I didn't want to undercut him.

NORBERG: Okay. But in fact, he made some recommendations there that would require at least a positive nod from the ACM Council. In the letter, he suggests that these changes that he's proposing would make the association more responsive to the individual members. And the way that was going to happen, that any proposal that was made, had to satisfy two important criteria before anything would be adopted. One of those must be enthusiastically accepted by the ACM, but what does "enthusiastically accepted" mean here? We're talking about the Council, we're talking about the membership, we're talking about special interest groups, and so on. That was not laid out. And the second was, it must be integrated into our planning and budgeting processes, and therefore you have to have a Long-Range Planning Committee to be permanent. Otherwise, that's not going to work.

ABRAHAMS: Right. Well, as far as enthusiastically accepted, you've asked exactly the right question. I see the membership as this amorphous mass that has, at most, statistical opinions, but my assumption about most members of organizations like this is that they're pretty passive.

They're consumers. They have about the same relationship to ACM as a Prius buyer does to Toyota. Then there is some smaller number who are actually active in the organization, but it's a very small proportion of the total membership. To understand ACM politics and even ACM elections, you have to realize that most people are passive. I think that's something that, often, people on the Council and the volunteer community didn't fully appreciate the utter passivity of most of the membership. And it's not going to change. You just have to say, "Well, that's how it works."

NORBERG: He listed some other things too, if I can find that quickly. This is one of your letters, "A Farewell to the NCC," which was kind of interesting, I think.

ABRAHAMS: But all this stuff that I haven't thought about for 20 years.

NORBERG: Well, let me just summarize what the position was that you were trying to get across to the organization. You indicated not just in that letter, but in some other places as well: Researchers are an essential part of ACM, but by this time, they're no longer dominant.

ABRAHAMS: That's right.

NORBERG: So there's some dissatisfaction. The dissatisfaction seemed to be focused on Communications as an independent journal. 
ABRAHAMS: Oh, yes.

NORBERG: It seemed to be a difficult balancing act. In addition to that, you add on the growth of microcomputers, which the organization wasn't serving at all, and you complicate the matter even more by throwing in the overseas members. It even gets worse.

ABRAHAMS: Oh, yes.

NORBERG: How was the Council dealing with this during your administration? Were they making any attempt to balance these?

ABRAHAMS: Not in any coherent way, as I can remember. They were dealing with each problem individually. I don't think they thought of the problem, say, of the overseas members as somehow related to the problem of the microcomputer community or personal computer community. I just want to take out a moment to read this. I did say it very well here: the Woody Allen attitude. [Laughter] You know, this may sound a little bit egotistical, but when I look at something like this, my reaction is, "Gee, I really understood what was going on there, and I expressed it very well." But 23 years later, I remember none of it. Or hardly any of it.

NORBERG: Of course. That's why I bring these things with me.

ABRAHAMS: You're right. It's very useful because I feel a lot of the-- You know, when I think about, "What is my perspective on all of this now?" The answer is, I think I have a little more wisdom about it. Maybe even a lot more wisdom about a lot of it. But as far as the specifics of the issues I dealt with, even the things I was trying to do, there was much that I understood then that I simply have totally forgotten now. When you ask what were my objectives and what were the major initiatives, I could have answered that 20 years ago.

NORBERG: Well, yes, but then it might have been a different kind of answer.

ABRAHAMS: That's right. So I guess I must say in my own defense, that the fact that I can't answer it now doesn't mean I didn't have a good answer at the time.

NORBERG: Of course. No, I'm trying to see this as a coordinated statement.

ABRAHAMS: Okay. Fair enough.

NORBERG: What this letter said to me was that the loss of funds from the NCC meant that the ACM management, both volunteers and staff, needed to be overhauled in order to sort of cover the losses that are starting to occur here by NCC, and that the Council and the staff has to know how they're going to deal with it.

ABRAHAMS: Well, there are a couple of ways. First of all, this did not happen that suddenly. It was happening for a while, so there was time for the organization to adjust to it. One way is to cut, do you increase taxes, do you decrease spending, or do you do some combination of them. Another aspect of that is, how much do you dig out of reserves, which reminded me of another 
one of the financial issues that I got very involved with, which is, how much reserves did ACM need, and how were they accounted for? There were different guidelines there. I don't remember exactly what they meant, but there was a $5 \%$ guideline and a $10 \%$ guideline, and they were basically how much you can spend down. I felt at the time that they weren't really being done correctly, and the result was that ACM was being more conservative than it needed to be and wasn't doing as much as it should or could.

NORBERG: But where did these reserves come from?

ABRAHAMS: Accrued membership dues, mainly. That's where accrual accounting entered into the picture. In other words, especially when you have a multiyear membership, you collect the dues to pay for future issues that you're obligated to deliver. So the question was how did it account for that? And then there's the actual money beyond the obligated money, which is basically the excess of the dues over what you are actually spending the money.

NORBERG: How does an organization get the dues to be high enough to generate some sort of a reserve?

ABRAHAMS: Well, the Council sets the dues, and then you set them to pay for what you want.

NORBERG: Well, we have to recognize that some people are going to drop out as a result.

ABRAHAMS: That's true. That's an optimization problem. And I couldn't tell you now, really, about how do you figure out what's the right price level for anything? How elastic is the market? The answer, I think, is probably it shows up when you raise dues, but then you lose some number of people. If you raise them 50 cents, you lose just a couple; if you raise them $\$ 50$, you lose a great many. So what's the right number in between?

NORBERG: So this is another one of those things that you have to deal with on a continuing basis.

ABRAHAMS: Oh, yeah. But you don't raise dues too often. There's even questions about that. Do you do it on a regular basis? Do you do it on a sudden basis?

NORBERG: Yes. The $5 \%$ and $10 \%$ that you were talking about seems, to me, the preparation of the budget.

ABRAHAMS: Right.

NORBERG: Here's what the budget would look like with 5\% reserves, and here's what it'd look like with $10 \%$. What sort of debate did that generate within the Council when these budgets were presented?

ABRAHAMS: Debates about the guidelines are independent of the debates about the particular budget. What should the guidelines be? And then whatever they were, basically, that set a constraint on the budget. And it was different constraints or different interpretations of the guidelines. The way the budget debates worked, technically, was they broke down into-- I guess 
there would be different parts of the organization that would propose what their budgets should be, and then these got all consolidated at headquarters and analyzed and turned into statistics. And then when it ultimately hit Council-- I think the Executive Committee had a whack at it at some point and made changes to it to bring it into line with what looked feasible.

NORBERG: There were some limitations on that though, weren't there? As to how much you could change it?

ABRAHAMS: I don't think so. I think it was really up to the Executive Committee, what they wanted to propose, and then there's the Council. The Council could increase or decrease any line item, basically. They could say, "We want to put more money to this," or "We want to take some money out of that." So it worked by amendments.

NORBERG: But wasn't there a maximum that you could change? $\$ 25,000$, for example? Or was that adding new things you couldn't go over 25 , without getting the approval of the membership?

ABRAHAMS: Oh, that was what you do during the year. In other words, what can you change about spending levels once the budget has been adopted? That's what that was about.

NORBERG: I see. Okay.

ABRAHAMS: How much flexibility is there, which reminded me of another thing I forgot to mention earlier. I told you about the problems I had with Adele, and that led me to propose something else which got adopted. It wasn't in effect when I became president, but I thought it was the right thing to do. The idea that the president should have control over the president-elect and have to approve all expenditures on behalf of the president-elect - and there are someseemed, to me, not right. So I proposed that there be a president-elect contingency fund. The president had a contingency fund to basically spend any reasonable way you want. The president-elect, I thought, should have one, too, that's specifically not under the president's control. And that did get adopted.

NORBERG: That seems peculiar to me not from any logical point of view, but the presidentelect learns that he or she has been elected at the beginning of May, don't they?

ABRAHAMS: Something like that.

NORBERG: So they're in for months, or less than two months. What sort of expenses are they going to have?

ABRAHAMS: Travel, for example.

\section{Session 2, Tape 3, Side A}

NORBERG: You had mentioned a contingency fund that was developed for the president-elect. 
ABRAHAMS: Right.

NORBERG: What about the past president? Any money there?

ABRAHAMS: No, not as far as I can remember. I remember several people, including me, said that it was probably the cushiest job in ACM. [Laughter]

NORBERG: The past president was the cushiest job.

ABRAHAMS: Very cushy.

NORBERG: Why is that? Didn't have to do anything?

ABRAHAMS: You didn't have to do much. You got to be listened to and have a lot of fun basically. The primary function of the past president, as far as I'm concerned, and I think that's how I also saw it at the time, was as adviser to the president. As more than an adviser - as an educator. You teach the president. Basically, when you come into office, you know nothing and the past president knows everything.

NORBERG: The third item that came up - and this has a very serious implication, I think, for the organization - is you were discussing activities that were directed at the general computing community and the public.

ABRAHAMS: Yes.

NORBERG: And that there seemed to be, at least, belief among some of you that the ACM was not the spokesgroup for computing issues, and you thought it should be. Is that right?

ABRAHAMS: Yes, I think that's right. As well as I can remember, that's a fair statement.

NORBERG: I want to broaden that because it seems that in the January 1988 letter about the state of ACM, you noted that every indicator used by ACM to understand the membership distribution was down. Student groups, chapters, special interest groups, and so on. All down. You thought that three things were needed. One, the will to stop this trend. How would you do that? How can you stop a trend of that kind unless you get a foundation to give you the money and you don't have to charge anybody any dues?

ABRAHAMS: I think that Dick Hespos's comment about what the problem was, the way he put it was, "The dogs don't like the dog food." [Laughter]

NORBERG: How are we going to find a better brand that they will like?

ABRAHAMS: You change your offerings so that they do like it.

NORBERG: But if you have no control of the Publications Board, how are you going to change the offerings? Because that's the principal-- 
ABRAHAMS: You may not have control of the Publications Board, but if you're lucky, you may be able to enlist them in the cause. You can't force them. You can't conscript them. But you may be able to inspire them, which, in a way, comes back to, again, the same idea of the presidency as a bully pulpit. Perhaps the biggest thing that the president can do is to inspire. Not the powers you have, but more the fact that you are an authority figure, and therefore, people will pay attention to what you say. And if you say the right thing and say it in the right way, people will respond in a useful way.

NORBERG: As an aside, did you have that idea when you became elected? Or was that something that came to you after you tried to deal with questions?

ABRAHAMS: I think I probably had some of it, even before I was elected. It became more of an idea later on, and it's even more of an idea now in looking back at it because I think it applies not just to me, but to other presidents, too. But if I ask, "Well, what did they really do?" even the most activist and effective among them - and probably David and Adele would be right up there - didn't change the world. Even though I had these terrible problems with Adele, I still ultimately respected her abilities. She probably would never say the same of me, but that's what I would say of her.

NORBERG: Maybe after 20 years she might, Paul.

ABRAHAMS: Maybe she would; I don't know. But ultimately, what did she accomplish? What ripples remain of her presidency? Maybe I just haven't been keeping up with it. My guess is, not very much. Basically, she kept the ship from sinking, and maybe made it go a little higher in the water. And that's enough because not everybody can do that.

NORBERG: The second thing that you discussed in that report was that the organization needed to evaluate and make the product better.

ABRAHAMS: Yes, which is changing the dog food.

NORBERG: Yes. So these two are intimately connected if that's the case. Maybe the answer for one is the same as the answer for the other, so why separate them out?

ABRAHAMS: Well, let's see. What was the first one again?

NORBERG: The first one was the will to stop this trend, that is, the downward trend in all the indicators.

ABRAHAMS: One of them is, recognize the importance of doing something, and the other is doing something. The first one is prerequisite to the second, I would say. To turn it around, if you say, "We don't care about this," then why ever bother with these improvements? So you first have to decide that there is a problem and you need to deal with it. Step One and Step Two. Step One will say, "There's a problem and here's what it is." Step Two is, "Here's how we fix the problem." 
NORBERG: Okay. Did the need to expend resources happen, even if it meant deficit spending for a year or two.

ABRAHAMS: Yes.

NORBERG: How did the Council react to that?

ABRAHAMS: Variably. [Laughter] I think some people agreed with it more than others. Depended on whether you're a deficit hawk or not. That was fairly controversial. Some people are very conservative financially. I was less so. Depends: are you an optimist or a pessimist? If you're a pessimist, you say, "You spend the money now, you'll never see it again." If you're an optimist, then you say, "Spend the money now, you'll get it back tenfold." So that's the difference between the two of them.

NORBERG: So you were the...

ABRAHAMS: I was an optimist.

NORBERG: You're the "glass is half full," right?

ABRAHAMS: That's right.

NORBERG: Not empty.

ABRAHAMS: Exactly.

NORBERG: Okay. At this time then, you appointed that Facilities Planning Committee. Their first task was to determine needs before 1992, when the lease on the New York property came to an end. That never happened. They didn't move until 2004 or 2005.

ABRAHAMS: Oh, no, they did.

NORBERG: They did? Where'd they go?

ABRAHAMS: I'm trying to remember. They were in one place on $6^{\text {th }}$ Avenue, and then they moved to $42^{\text {nd }}$ Street.

NORBERG: But still in Manhattan.

ABRAHAMS: Yes.

NORBERG: Okay. But now they're moving a large part of the operation over to New Jersey.

ABRAHAMS: I didn't even know that.

NORBERG: That's what I was told. 
ABRAHAMS: But there was a move within Manhattan. I don't remember the sequence, but I think there were two. There was once, when they had the headquarters on $6^{\text {th }}$ Avenue, and then they moved up to $42^{\text {nd }}$ Street, and then they moved again to Broadway. But I don't remember exactly what happened when. I just remembered that there were two moves that I was aware of.

NORBERG: What was the advantage of moving in terms of lease costs and so on?

ABRAHAMS: I think in one case, where they were about to lose the lease or be hit with a huge rent increase. The first move I don't think was because of any inadequacy of the space. I think the second one may have involved that, that the space was just not working very well. But that I'm not sure of. Jack Esbin was handling a lot of that, and he was very good at it.

NORBERG: Six months later, in your valedictory letter, you noted changes in the budget, and a Capital Improvements Fund enters the picture. The Capital Improvements Fund is different than the reserve, isn't it?

ABRAHAMS: Yes. It was money that set aside specifically, as I remember it, for certain kinds of things. You know, vital structural improvements that were not immediately incomeproducing, and were too expensive to be paid for all at once

NORBERG: "Structural." Would you explain that to me, please?

ABRAHAMS: I'll give you an example, although I don't know if it was an example that really happened: improve computer facilities at headquarters. That's the only one that occurs right off. Certainly, headquarters improvements would be there. I don't remember what else I had in mind at the time.

NORBERG: Well, let me try to give an example that we've used at the Babbage Institute and see whether that rings any associations for you. One of the things that I found after being in the job as director for three or four years was that I had been budgeting to buy new equipment as I needed it, and not providing any accrual of capital funds along the way such that when I got hit with the expense, I had to come up with even more money.

ABRAHAMS: Oh, that's exactly right. The only thing I was wondering about is who needed equipment other than headquarters. And I was trying to see if I could think of any way that anyone outside of headquarters would have had use for capital improvements, and I couldn't think of anything.

NORBERG: Probably none. Did this include any changes in the property itself? Not the computing property now, but the offices. Painting the walls and that type of stuff.

ABRAHAMS: Probably did, but I can't remember them specifically.

NORBERG: Okay. Paul, who were the officers you worked most closely with over the 1980s?

ABRAHAMS: Dennis Frailey, David Wood, Jack Esbin. Those are the ones that immediately come to mind. 
NORBERG: I notice you didn't include Brandin and Goldberg in that.

ABRAHAMS: No. I told you the story of the Executive Committee when I was vice president. Basically I was shut out by both of them. My relationship with Dave Brandin subsequently improved greatly and became, I wouldn't say fast friends, but certainly friendly. When you look at the tone of some of the things he wrote to me, they were very friendly and in no way negative. So his attitude towards me changed. Adele's, as far as I know, never did.

\section{NORBERG: What about Denning?}

ABRAHAMS: Denning, a little bit. Again, he was never really a colleague in that sense. We did have a few good discussions now and then. Once in a while. In fact, one of the measures of who I was really working with was, was I ever in their house? Other than an ACM party. Like, I was in David's house once for an ACM party, but there were a whole lot of other people. I guess I was never in Jack Esbin's house, but that's only because of where he was living. But I spent a lot of time talking to him. We went out to dinner often together at meetings. Same thing with Dennis and same thing with Dave Wood. With Dave Brandin, I think I had drinks with him a couple of times. There was one other person I was just talking about, and I can't remember who it was. Who was that now?

NORBERG: Ashenhurst came up.

ABRAHAMS: Ashenhurst, I never had much association with. Except with SIGBOOZE, which was a remarkable organization in that it really was quite a lubricant to social relationships and therefore working relationships, much more than one would ever guess. It was really a very good thing. Even people who never dropped in.

NORBERG: I can understand that without any reservations, but it seemed to me that David, in his interview, led me to believe it was, at least to these four or five people at the top there, that it was more than just involvement at the annual meeting or whatever. These guys went on scotch tours and they went scuba diving and so on. I mean, who are these people? Ashenhurst was one of them. D'Auria was another.

ABRAHAMS: I didn't even know about that part of it. I don't think that they ever mentioned it to me. But you mentioned Denning. I was in his house once. In fact, I remember visiting him out in, I guess it was Palo Alto where they were living at the time. He and Dorothy and me went for a hike nearby. He was fairly interested in my knowledge of wild mushrooms, so we'd go looking for mushrooms in that area. Didn't find many, or maybe didn't find any. I don't remember. But we were talking together, so he was pretty friendly to me at that point. We had a couple of times when we went together on-- you know, we're going to same place or we were stuck together on an airplane. So he became more friendly to me at a certain point. We had a kind of institutional conflict when he was president and I was SIG Board chair, and we always had this little political disagreement, which I found kind of picturesque in a way. What also struck me as picturesque was that he could never really acknowledge it for what it was. It seemed as though he couldn't just say, "You know, Paul, you're a liberal and I'm a conservative." He could just never bring himself to say that. 
NORBERG: It really is difficult. I have a friend in the same way where he is the conservative and I'm the liberal, and we just don't talk about politics because we're not going to see eye to eye at all. Okay. This criterion about being in the house seems to me to be a pretty strong one.

ABRAHAMS: It's not necessary, but it certainly is an indication.

NORBERG: Perhaps, yeah. I won't argue that with you. But I was thinking back to my own associations with officers in various groups that I was an officer in. Rarely did we ever get into each other's homes. In fact, I only did that for close friends that I had known for years. The one place that it was different was over in England, when I went over there and was meeting with some people there and was invited to a couple of parties. But again, that wouldn't have been my criterion to try to evaluate who's a friend. In fact, what I think I would say is my criterion is being able to talk about one's work together. There is a very small group, and it's getting smaller every year now, of people who work on particular problems in theoretical astronomy, the history of it, and we always made it a point to get together at the annual meetings, but I don't think I was ever in any of their homes. See, it's an interesting criterion.

ABRAHAMS: It's not necessary, but it's sufficient.

NORBERG: Sure, yes. It's sufficient to indicate what the relationship is, true. You didn't mention anybody at the ACM headquarters.

ABRAHAMS: I would have dinner with Hespos occasionally, as David suggested I should. He made the suggestion after I was already gone. There was that marvelous boat trip that I mentioned.

NORBERG: Boat trip?

ABRAHAMS: Remember I said I visited him in Westport? Very nice boat. But I don't remember that I really became terribly friendly with anyone at headquarters to the extent that I would just kind of socialize with them. One person I was sort of friendly with - but he was friendly with everybody — was Jim Adams. He was ACM's ambassador at large. He was deeply devoted to the organization. Aside from being in SIGBOOZE, he got SIGs organized and he was very active in chapters in addition to being-- I don't remember what his title was at headquarters.

NORBERG: Who was the treasurer during your term of office?

ABRAHAMS: Jack Esbin.

NORBERG: Oh, so Finerman was no longer treasurer then.

ABRAHAMS: No.

NORBERG: Okay. Did you have any interaction with Finerman? 
ABRAHAMS: Very little. The thing I remember was the scientific freedom and human rights business, the Sharansky affair. I guess the best way to describe people's dominant attitude in Council was, "We don’t really like this, but we don't quite know how to say no."

NORBERG: All right. I've picked up a particular view of yours as I was reading various kinds of materials, and I'd like to present it to you now. You wrote this one of your Communications articles. I quote: "ACM, by its charter, is a scientific and educational society that exists primarily for the benefit of the public rather than exclusively for its members." I would not have used the word "primarily" here. It doesn't fit. But the way I read the charter, and I'll quote that too, "ACM delivers resources in advanced computing as a science and a profession. ACM provides the computing field's premier digital library and serves its members in the computing profession with leading-edge publications, conferences, and career resources." I see a conflict there between your statement in your...was it in your valedictory? I think it might be that.

ABRAHAMS: Yes.

NORBERG: And what the charter says, whereas you were trying to convince the reader that this is what the purpose of the organization was. Do you remember that at all?

ABRAHAMS: I don't really remember it. I can try to reconstruct it. That tension was always there, but then the question was, what does it mean to serve the public? If you decide that that's all we're there for, what services does one render to the public? It isn't a very long list. Maybe some of the educational stuff. The K-through-12 programs and stuff like that. The things the Education Board does. Maybe some of the external activities. The scientific stuff only indirectly, but you could argue that though it's indirect, it's very important. By advancing the art and scientific community of computing, we are rendering a public service, we are just not rendering it directly.

NORBERG: Ah, okay. All right. Now, I didn't read that into the statement at all, and I would've expected...

ABRAHAMS: I may not have read it either that way. [Laughter]

NORBERG: That's why I questioned the use of the word "primarily." I would've expected somebody to say "among our." And this is a very important one for the following reasons. But that's not the way it was reported, and I was wondering if you could remember what you had in mind there.

ABRAHAMS: Maybe I was thinking about the fact that if you interpret the beginning of that charter very literally and unimaginatively, then ACM probably has no business doing much of what it's doing.

NORBERG: Oh, I guess I wouldn't go that far.

ABRAHAMS: Yes. How is it serving the public? Only indirectly. I mean, if you really are trying to be as skeptical as possible about it, you could make that argument. The public doesn't read the publications. 
NORBERG: But doesn't this go back to an earlier topic we were discussing, and that is ACM becoming the spokes-group for issues in computing rather than letting it, by default, go to IEEE $\mathrm{CS}$, or something like that?

\section{ABRAHAMS: Yes.}

NORBERG: That's the same sort of thing. If you were to educate certain members of Congress, for example, such that they knew something about the computing issues a bit more knowledgeably than they had at the time, that is not a violation of your charter because it's not lobbying. Only after you cross that fine line does it get to be an issue.

ABRAHAMS: It's one thing to talk about violations of a charter; it's another thing to talk about, let's say, imaginative interpretations of it. You actually can do a little bit of lobbying, but I would say if ACM primarily did lobbying, then they would be in violation of the charter. I think partly the problem I was dealing with was the difference between what the charter says and what ACM actually does.

NORBERG: Were they actually doing that, then?

ABRAHAMS: Well, I wasn't thinking of that, but the fact that there are all these activities of basically serving the profession rather than serving the public. The conferences- the public doesn't go to them. The publications - the public doesn't read them. So how is that serving the public? Well, I gave you an argument that it is, but it's doing it indirectly. But if you're really trying to be as skeptical as possible about it, you'd say, "ACM shouldn't be doing these things because what do they do for the public?" If you really want to be skeptical and literal-- I mean, I don't argue that that's right, but if you took that viewpoint, that's the conclusion it would lead to. Or looking at it another way, how do you justify all of this in terms of the charter? You can do it, but it's a stretch. But that's what I was trying to do because I felt we have to. This is what we're doing, and how do we justify it in terms of our charter? The fact is, the charter says this, we're doing that. So what do we do now? Do we say, "We'll stop doing it because it's not in the charter"? Or do we find a way of relating it to the charter?

NORBERG: It seems to me that this topic came up in the context of discussions about whether the label of the organization should change and become a 501(c)(6) rather than retaining its $501 \mathrm{c}(3)$ category.

ABRAHAMS: That had to do with another issue, which was the whole question of the profession versus the science, or, let's say, the economic interests of the membership versus the intellectual interests of the membership. The publications and conferences and all that stuff serves the intellectual interest. The professional interests have to do with things like that tax issue about the independent contractor status of certain computer consultants. You can think of other things that affect-- if you regard ACM as a union, you know, what would unions do for their membership? That's the purely economic view, and that's what we didn't do. At times, we got pushed to do that a little bit, like in the tax issue, but how much do we really want to and how much should we? Especially given the fact that that our membership does not have a unitary interest. There are the people who are working are programmers, and there are the people who 
are working as academics. Their interests are not the same. Academics care about tenure and things like that. Programmers care about salary raises, economics.

NORBERG: In the academic case, though, most professional organizations will help that person get tenure and so on through the credential way, as you talked about it yesterday. But nobody's going to be able to get a raise for programmers in industry, say.

ABRAHAMS: I guess the IEEE actually is a little closer to doing that than they were. If you ask, well, if we did for our members what the Service Employees Union does for garbage collectors, that is real economic assistance.

NORBERG: Yes, it is.

ABRAHAMS: One could imagine an organization like ACM doing that, but of course, then we'd have to change our constitution and our tax status.

NORBERG: Now, we talked about a number of issues faced by the association. Scientific freedom issues, the computers and public policy issue, and so on. You took a position during your presidential years that ACM must respond to the growing role of personal computers and their users.

ABRAHAMS: Yes.

NORBERG: Were there any results of this?

ABRAHAMS: Yes, but I think slowly. I don't think that it happened right away. I think there was a SIG that was supposedly in that area but wasn't really, SIGMICRO, which didn't have all that much to do with personal computers. I think it showed up in just the kinds of things that were getting printed in CACM. After my past presidency, I really didn't keep track very much of what ACM was doing just at the time that this sort of thing was really exploding, and everybody has computers now. But it was happening right then.

NORBERG: What I was getting at was, did the accumulation of three special interest groups that were dealing with either micro or PC or whatever, did they get coordinated during your term, or not? That's what I meant by "any results."

ABRAHAMS: Yes. I'd have to say that I may not have had many specific ideas of how to achieve this. I just thought it was worth achieving, but I didn't really know how.

NORBERG: Because there was some correspondence with a woman from Texas (which university, I can't remember now) about providing more options and possibilities for the people concentrating on PCs and Macs within the organization. At that point, several of these groups were brought together as one special interest group rather than having them all separate to be dealing with separate issues. But you don't remember that. 
ABRAHAMS: I don't remember that, although that probably would've happened within the SIG Board. I might have kind of pushed it a little bit, but that would be the natural place for it to take place.

NORBERG: Electioneering.

ABRAHAMS: Electioneering. Okay.

NORBERG: We talked a little bit about electioneering.

ABRAHAMS: And I assume IEEE Computer Society is on the list too somewhere, right?

NORBERG: Well, we talked about them before.

ABRAHAMS: Not really, no.

NORBERG: Oh, all right. Then correct me.

ABRAHAMS: Okay. That was one of the major things that every president dealt with, and probably, they still do - the relationship with the Computer Society. Because it's a love/hate relationship. On the one hand, you're competing with them for resources, conference revenues, and members. You have joint conferences sometimes-how does the money get split up? So there's a lot of competition, but at the same time, there are also a lot of common interests. So one result of this is there's a lot of schmoozing between the officers of the two groups, as there should be. Used to place take at NCC. It was still happening. I don't remember exactly where, but often, ACM officers were invited to Computer Society meetings, and vice versa. So there was a lot of interaction. Some of it happened in AFIPS, too. There was a lot of talk of merger, and it probably got about a third of the way. But ultimately it floundered because the Computer Society was not an independent organization, even though they often themselves would have liked to be. The big competition was for members, as I remember, but there were also crossdiscounts. So there was some motivation there for people to belong to both.

I remember spending a fair amount of time with Roy Russo, who was the chairman when I was. I guess Oscar Garcia was president during the first few months because their election cycle is different from ACM's. I don't remember all of the things we talked about, but I did remember that we talked quite a bit, Roy and I. I remember going to a couple of board meetings. I can't remember whether it was the IEEE or the Computer Society, but I think it was actually the IEEE itself. Then there was the fact that they really regarded themselves more as a professional society than a scientific society. There were certainly overlaps - in particular, the areas of software engineering. That was a big one. I can't think of anything more about that right now. I may think of some other things. But it was certainly a big issue. Some things took a lot of attention.

NORBERG: Okay. I was going to bring up the election area again, but we've gone over that twice now, so we'll drop that. In one number of your presidential letters, there was some discussion about the CSNET and the problem with so many networks being developed that were not able to communicate across the interface between the two of them. This was done when you were vice president. It was actually published in April of '83 as "Electronic Islands." 
ABRAHAMS: Yes, I remember that very clearly.

NORBERG: Now, this is a letter that doesn't really fit into those other four that I talked about, which were not confined to issues of the society and with the membership. So, here we have a situation, which I think is somewhere else in there, because the timing is particularly good.

These different networks are becoming a real problem for communication, and something needs to be done. It seems to me ACM is the most appropriate one to be the leader in this area. What was the reaction to your letter? Do you remember?

ABRAHAMS: No, I don't remember. [Laughs] What strikes me, looking back at it, is that the problem solved itself.

NORBERG: Oh, I wouldn't say that. Why do you think it solved itself?

ABRAHAMS: Because, basically, Internet access became universal.

NORBERG: But that didn't solve itself. That had to come out of NSFNET and CSNET and a few more of the large, overarching networks that cost a lot of money.

ABRAHAMS: Well, it took more than that because universal access didn't take off until the commercial outfits got into it. I don't remember whether AOL was the first, but they were pretty early. I think there were ones before that. But there was a point that was not too long after that where you plunked down your 20 bucks and you had a connection. You didn't have to be anybody special.

NORBERG: That's true.

ABRAHAMS: That was the solution. I didn't fully appreciate it at the time, maybe because that seemed like it was beyond reach. But that was really what I was kind of hoping for, without articulating it even to myself, to reach the point where anybody who plunked down their $\$ 20$ gets on the Net. And that's certainly how it is now.

NORBERG: Yes, it certainly is. The last letter I want to bring up is export controls.

ABRAHAMS: Yes.

NORBERG: The last letter I want to bring up is the one about export controls. This, during the Reagan administration, seemed to me was a real problem. At the time, I remember thinking that these people that they're trying to keep from getting these devices are easily going to get them. I was in a computing museum in Germany not so many years ago, and there was a Soviet version of the IBM 360, and it was very clear that they were related. Now, this is a political question in many respects, isn't it?

ABRAHAMS: Yes. 
NORBERG: So it fits into this gray area that we've been talking about as to whether or not these were appropriate things for the ACM to be involved in.

ABRAHAMS: I guess that the decision to get into them, or not get into them, really, is almost a product of two different numbers. One of them is the importance of the issue, and the other is the politicization of the issue. In other words, if something is not terribly important but also very political, that's what you don't want. Something that's just a little bit political but very important, that's different. But you reminded me of another president's letter, which you didn't mention, which was the one about SDI, and that was political. That produced quite a reaction, both pro and con. That was a controversy within the computing community generally.

NORBERG: Did you expect to have ACM do anything with that issue?

ABRAHAMS: No, I didn't. I just thought that was another bully pulpit example. I felt, and I guess I still feel that that is one of the responsibilities of the ACM president. Responsibility or prerogative, depending on how you look at it. But to act, in some way, as a thinker or as a preacher in the computing community. In fact, that fits in very well with the notion of public responsibility. To the extent that these are public issues, it's appropriate for presidents to address them. Like any preacher, you're expressing your opinions, but in a sense, that's what you're there for. Who wants a rabbi or a minister with no opinions?

NORBERG: Of course. Yes. You know, I raised that one because it allows me to lead into another question about whether or not, during these years you had any service on other nongovernmental boards that had some real influence. I'm thinking the National Academy of Sciences.

ABRAHAMS: No, no. It was pretty much that and-- I was pretty active in CSSP, but that was an ex officio thing, really. But I was quite active there.

NORBERG: But when it comes to coordinating with other groups--

ABRAHAMS: Nope. Literally, this was it. ACM was it.

NORBERG: Okay, that was it. All right. Let me ask you to summarize here what we've been talking about, about your two years as president. What do you think ACM's strengths and weaknesses were when you were president? Not necessarily for you to change them, but just to understand what they were.

ABRAHAMS: Well, ACM called itself the premier society in computing, and I think it really was. Its strength was getting information out, primarily to the professional or academic community. The computing people who could use information, ACM got it out to them. It was a primary source. Better than anything else out there. I think that was a real strength, and it was a very important one. There were other strengths, but even if ACM did nothing else but publish journals and stage conferences, it would be a worthwhile organization. The weakness was that it tended to be bureaucratic and slow moving because power within the ACM was so widely distributed. It also meant a lot of organizational inertia. So ACM had a hard time changing course because there were so many people who had a stake in everything that happened and 
could make themselves heard. The president really had-- I mean, it wasn't just me. I think with every president, you really have very limited power. The only real power you have is the power to persuade. And even that is limited when people have their own ideas. They don't have to listen to you if they don't want to. So the most effective presidents, I think, have been the most persuasive ones.

NORBERG: And who are they? In your time.

ABRAHAMS: I'd have to rank Brandin very high. Denning and Goldberg would be pretty close. And then there were the real oddballs in their way, like Sammet and Grosch. Then there were people before that who I didn't know very well but I had the sense were very good, like Ralston. Before that, I couldn't really say. I just wasn't involved enough. Before 1978, ACM was just the publisher of things I read, and that was it.

NORBERG: All right. We've covered a lot of ground today. Can we cover one more topic before we leave?

ABRAHAMS: Sure.

NORBERG: And that's the topic of science education and training. ACM was very good at developing these issues in its various curricula. It established a Curriculum Committee very early on in the early 1960s, as I remember. No, 1950s. Even before Sputnik, the association was interested in these questions. As I understand it though, as I read through various documents in the association, this work has tended to diversify over time. At some time, it focuses on one particular direction or set of philosophic principles of education. Another time, it's on a different set of technical questions, and therefore, a different educational philosophy must be apparent in those. Do you recall what some of ACM's major initiatives were in the area of education?

ABRAHAMS: Mostly, that was what the Ed Board did. I figured they were doing it, and I wasn't too much involved. I said, "More power to them." There was one area I did get involved in, which was accreditation of computer science programs. There were questions about the extent to which ACM should be involved in that issue. There were a lot of other players at the table - what should be done about it? I don't really remember how that played out, but I do remember being quite involved in it and very interested in it. There were a lot of questions about, how much was this like an engineering program? Who are the other players at the table in accreditation? Trying to remember what else went on with that. I know I went to a few meetings on the subject. There were a couple of big controversies. There was some other organization that was in the accreditation business that was a model, but it wasn't clear that it was a good model.

NORBERG: ICCP, maybe?

ABRAHAMS: No. Oh, ICCP was a ridiculous organization. [Laughter] Even though I got their certification.

NORBERG: Okay, I didn’t say that. 
ABRAHAMS: I don't even know if they're still around.

NORBERG: It isn't.

ABRAHAMS: Very strange notions of what constituted competence in computing.

NORBERG: Okay. So you were looking for another organization that...

ABRAHAMS: Yes. There was one that was actually doing accreditation-not in computing, but something very similar - that served as a model. I don't remember the details of it. I just remembered that there were issues about it, and that we were not the only players in the game, but there were other players who looked like they might have the right idea. We wanted to support what they were doing, but I can't remember who they were or what the ideas were. We definitely were not alone in this business.

NORBERG: I wonder if the other organization was one that was dealing with the larger question of science and technology, and that computing was only one part of it.

ABRAHAMS: I don't think so. I think with more the professional end of it.

NORBERG: Could it have been IEEE?

ABRAHAMS: Yes. IEEE was certainly involved in it.

\section{Session 2, Tape 3, Side B}

ABRAHAMS: I remember one person who was very involved in this area: David Kniefel.

NORBERG: During your term, Curriculum ' 88 was introduced. The report itself that you gave showed significant chronology about ACM's involvement in education and so on. That's where I picked up this idea of different emphases, and therefore different philosophies needed to teach them. You didn't participate in any of that, I take it.

ABRAHAMS: I may have participated kind of on the side, but it was not one of my active interests. It was one of those things where I felt it should be done, but I was very glad to see someone else doing it. So I just didn't step in; I just let Dave Kniefel deal with it. That's what the Ed Board does.

NORBERG: But wouldn't you be interested in that for your position at NYU, though?

ABRAHAMS: At that point, I wasn't at NYU anymore. Then I was living up here.

NORBERG: We'll get to that tomorrow.

ABRAHAMS: Yes. We should think just a little bit about what we want since you have to leave tomorrow. What do we want to talk about? 
NORBERG: Well, I think I would like to look into your successors, on succession, and then your activities after you left the ACM, your tasks as a computer consultant, insofar as you can talk about these things; there maybe proprietary information. I'd like to discuss with you something about what you believe your primary contributions to the field are. All of these are pretty straightforwardly listed on that, and that'll take us a couple of hours, I would guess.

ABRAHAMS: Okay. So we want to talk about, actually, the Kocher presidency, because after that, I wasn't really involved in anything.

NORBERG: Yes, but you already mentioned about Goldberg, so we've covered that one.

ABRAHAMS: Yes. But Kocher we haven't talked about at all.

NORBERG: Do you recall back in '81, I guess it was, when you were on the SIG Board, do you remember a piece that was written by Feldman? [Jerome A. Feldman, University of Rochester.]

ABRAHAMS: I remember Jerry Feldman.

NORBERG: He was a chairman of the committee that submitted a report to the National Science Foundation about the needs of education in computer science and engineering. Three of your illustrious colleagues took exception to this report and disagreed with it, and actually published a statement, which they had submitted to NSF, called "The Crisis in Experimental Computer Science." It was written by Denning, McCracken, and Brandin. I'm wondering if you thought about any of those questions at that time, when the ACM was developing new curricula and so on.

ABRAHAMS: I probably did, but I don't remember anything about it.

NORBERG: All right. Well, we can't say much about that then, can we? The other half of that issue, of course, is the manpower shortages.

ABRAHAMS: Yes. That was certainly a big issue. It's a fine example of bad thermostatic control. It seems that the supply and the demand are almost always badly out of balance, but in oscillating directions.

NORBERG: All right, I can accept that metaphor. But what about the relationship between manpower shortages-- on the one hand, Ph.D.s needed for industry and research and all that sort of thing.

ABRAHAMS: Oh, yes. I remember saying some stuff about that.

NORBERG: And the other half being those programmers that we talked about earlier, which really don't get any coverage in this discussion.

ABRAHAMS: I remember getting involved, in fact, fairly intensely in some of the issues about training and education and things like that. I felt that things were not being done right. I 
remember a couple of meetings where I was speaking up, but I can't remember exactly what I was saying. I just remember being involved in that and being very interested in that subject.

NORBERG: From what point of view?

ABRAHAMS: Basically, that the computer science departments weren't doing the job right. I remember Denning had this thing about, "We're eating our seed corn." I remember that. I think I agreed with him, although I may have had a somewhat different take on it. Maybe it was that the academic departments were shortchanging the pragmatic people. It may have been something like that, but I can't really remember anymore. I may remember by tomorrow, though.

NORBERG: It certainly does fit into that category, that the programmers or whatever you want to call them, software engineers and so on.

ABRAHAMS: I even remember this public meeting where a woman also spoke up with a very similar view. She was also active in ACM. Judith Schlesinger. I don't remember what she said and I don't remember but I said, but I do remember we were saying the same thing.

NORBERG: Can I elicit from you your opinion of what the proper computer science curriculum ought to be? Back in the ' 80 s now. We can ask you about today later on. What's the proper role of computer science education in the 1980s?

ABRAHAMS: I would have to say, generally, it was, first of all, to pass on the tradition. The seed corn. To educate the next generation of educators. The other thing is to educate the programmers - the people who will actually be doing the work. I guess that I probably felt at the time that the theoreticians were running the show a little bit too much. They were always the royalty, and I think that's still somewhat true.

NORBERG: They are in every field, every science and engineering field.

ABRAHAMS: Yes. That's interesting you should say that, but like you said, you've seen it. You've been involved in several fields, so you know much better than I do. But it's an interesting thing. They've become this kind of aristocracy, and everybody is just a little bit overawed by them, not least because they're some of the smartest people around.

NORBERG: True.

ABRAHAMS: But smart is not necessarily wise. In fact, one of the general observations I have - maybe it's about life - is that sometimes, the smartest people have not been the ones who were right. And I've certainly seen that happen in the computing field.

NORBERG: Can you give some examples?

ABRAHAMS: Yes. I think of, in artificial intelligence, Newell, Simon, and Shaw. Absolutely brilliant people. They were just wildly overoptimistic about artificial intelligence, but not out of 
stupidity. I thought of another example recently. Let's see if I can reconstruct what it was. Somebody just totally obliterated the opposition because they argued so cleverly.

NORBERG: Oh, yes, that's the network controversy where the network types were just frozen out of DARPA money as a result of the machinery people.

ABRAHAMS: In retrospect, they just got it wrong. I can't think of it now. I had a very good example of this phenomenon at one point, and I thought it was fairly recent, but I just don't remember what it was. But it's an interesting phenomenon.

NORBERG: Has your opinion about how computer science ought to be taught changed over the years since the ' 80 s?

ABRAHAMS: Not much, but it's not a question I've really been thinking about lately, so I'm not in the best position to answer it anymore.

NORBERG: Skipping over things since we talked about them already. We talked about the budgeting process at ACM. You thought that budget cycles were not sufficiently helpful. Do you remember that?

ABRAHAMS: No.

NORBERG: There was too much fluctuation in budgets and dues.

ABRAHAMS: I don't remember that.

NORBERG: Okay. You know, my experience with professional societies is that they were always in one financial crisis or another, partly because you can't put aside many reserve funds given that you have to pay for the day-to-day activities. Do you remember if there were any special challenges to this problem while you were president?

ABRAHAMS: The fact that the bank balance were going down, basically. That was a big concern. You can take different attitudes towards it. You can say, "Well, it's going down. The sky is falling in. We have to take drastic emergency measures. Go on an austerity program." Or you can say, "Well, the bank balance is going down, but there are these other reasons why in a couple of years it'll go up, so we should just be careful and things will get better." Those are two opposite attitudes.

NORBERG: Oh, they sure are. That's very optimistic, that second one.

ABRAHAMS: But sometimes one is correct, and sometimes the other is correct. The budgeting process, I got involved in a lot of how the accounting was done, and the whole issue about cost of servicing a member, which was a big issue. The process itself was $90 \%$ headquarters-driven, as I remember. The detail is overwhelming. It was very hard to get the big picture even for me, let alone for the average Council member, for whom it was not that much of a preoccupation. I'm not sure how it could've been done better, but I have a feeling it could've been done better; I just didn't know at the time, and I certainly don't know now. 
NORBERG: You mentioned a number of different kinds of information that you possess about people's activities within ACM.

ABRAHAMS: Yes.

NORBERG: What are the ones that we have not talked about yet? Do you remember those? We got talking about Goldberg and we got talking about some of the personalities in the financial side and so on.

NORBERG: What are the ones that we have not talked about yet? Do you remember those? We got talking about Goldberg and we got talking about some of the personalities in the financial side and so on.

ABRAHAMS: One thing I didn't mention is the question of whether ACM is an American organization or an international organization. People in ACM seemed to be of two minds about that.

On the one hand, ACM has many overseas members and pays a lot of attention to them. The overseas members have (or had) a regional representative on Council. And the rhetoric emphatically says that ACM is international. It doesn't even have "American" in its name. But still, it devotes a lot of energy to issues that are purely domestic, like software patents or that issues about the tax status of computer consultants. It doesn't do anything like that with similar issues overseas that don't transcend international boundaries. Maybe the views have changed since my time.

NORBERG: To your knowledge, Paul, did the origins of ACM, back in the late 1940s, leave any imprint on the organization by the time you got to be president? "What do we do because we always did it?" sort of question.

ABRAHAMS: The answer probably is very little, except for the very existence of the organization. I don't think they even had a headquarters initially. Basically, it was just a little publication that was shared among a few somewhat esoteric colleagues, and then it just gradually grew. Actually, I think my first connection with ACM was when I was given a free student membership when I was at MIT. That's how I kind of got roped into it. So I was a member for a long time even though I wasn't an active member, which describes a lot of people.

NORBERG: It does indeed. The reason I ask the question that way is that if you look at the steps by which the association generated its policies and procedures and generated its constitution, it strikes me - and here I'm accepting an opinion from Dan McCracken, though we haven't talked about it - that there was a major turning point in 1978. That is, by that time, the further changes that were made at one of these ACM Council meetings in December of ' 78 set the organization up for all of its future activities. I posed that to both Peter and to Dave, and they did not agree with that all. They didn't remember '78 as being any particular turning point. But one can look at the late ' $80 \mathrm{~s}$ and the budget changes and the loss of the NCC money and the fact that AFIPS was going down the tubes and so on, that here we have another opportunity to have a turning point. Did you? Do you consider that during your presidency, you faced a turning point in the way in which budgets were generated and managed and the way volunteer staff were used? 
ABRAHAMS: I don't think so. I think it was probably a fair amount of continuity. The changes had to do with, I think, the kind of services that were being rendered. New things started getting important. The ACM Library. There were big changes in Communications - the fact that it became a very different kind of magazine. Some things, as far as I know, still continue kind of the same, like the major conferences. They may be bigger or a little smaller, but they still have the same sort of character. Major turning points in ACM probably have to do with certain SIG conferences, if nothing else, because of the financial implication, but also, they attract a lot of attention and they generate a lot of activity. It's not just economic. I mean intellectual activity, too. OOPSLA was a big one. That was just starting when I was president; it wasn't starting when I was SIGPLAN chairman. People didn't even know about that. In fact, Adele's book on Smalltalk, which was instrumental in that, came out in 1980, when I was no longer the SIGPLAN chair.

As far as '78 goes, it's hard to say, because that's when I first became active. I guess I was aware of some of the-- you know, almost anybody in ACM could fail to be aware of some of the huge, cataclysmic personality conflicts. Grosch and Sammet being at the center of it. Their personalities and their activities, you know, they were having an effect for probably ten to 15 years in one way or another. Even when I was president, conflict with Grosch was a big deal. And you saw I had completely forgotten about that letter that he wrote, the one having to do with my election. But that was typical Grosch. I don't remember ever having a cordial conversation with the man.

Actually, as well as most of the other people I had difficulty with in ACM. I haven't spoken to Adele since my presidency, as far as I can remember. I may have seen her at some other meeting once. But just about everybody else whom I had conflicts with has gotten past it. Certainly Brandin is a fine example of that. If you ask him now what he thinks of me, he'd probably have a fairly positive opinion at this point.

NORBERG: He does. And he also admitted that you didn't see eye to eye between you either, at one point. But he has nothing but respect for you now.

Over the course of the last two days, today and yesterday, you have not mentioned computer manufacturers once.

ABRAHAMS: That's true.

NORBERG: Was ACM ever interested in some sort of corporate board or corporate contributors or anything of that kind, trying to get the interest of these manufacturers?

ABRAHAMS: We were always scrounging for money. I remember some issues about the funding of the Turing Award, which I think involved...I don't remember whether it was some corporate interest. IBM was the most obvious one. Much more recently, Microsoft's been very big in that sort of thing, which I think has created a little bit of a conflict of interest - more of a little bit of a conflict of interest for ACM. In fact, I think a lot of the stuff that Microsoft has done in the computing field is very destructive. But it's hard for ACM to say that because Microsoft has been a big benefactor. I can certainly opine on Microsoft; maybe that's not terribly relevant, being a Linux fan myself. But I feel they've done a major disservice to the field by the way they've leveraged their economic power. My favorite example is Vista. The question is, why do people use Vista? And my observation is virtually nobody chooses to use 
Vista. Very, very few people. Only real Microsoft diehards, and there aren't that many of them. People use Vista because they bought computers that have Vista on them, like this one. That's because of the deals that IBM has worked out with Dell and Hewlett-Packard and all of those guys, and basically saying, "You better put Vista on the machines you're selling, or else." So people who buy computers do not choose Vista; they are handed Vista. And as far as I can see, technically, it has no significant advantages and a lot of disadvantages. So that's an example of how I feel they've used their power not very well. Also, I think it's tended to repress a lot of innovation and a lot of progress. But then again, I'm kind of a free software fan, so that accounts for a lot of that particular bias.

NORBERG: Can we talk about Bryan Kocher now?

ABRAHAMS: Sure. I didn't realize you had time today. I have all day.

NORBERG: Well, no, I want to cut it off at some point here because--

ABRAHAMS: Okay. But I think it's a good idea to do that today. That's a very interesting story. There are many interesting stories of my days at ACM, and you've heard a lot of them. The vice presidential election is a very interesting story. Bryan was a petition candidate. He came out of nowhere. I certainly did not want to see him elected. He had been on the Council, I guess, before then, and just seemed to me to be kind of a rabble-rouser. A little bit of the Grosch model, but not as sophisticated, nor as loud, frankly. But when he was elected-- I told you my philosophy about this sort of thing, about the relationship between the president and the past president. I felt, while not agreeing with him or pretending to agree with him, I should still be supportive to the extent I could within that constraint. I should advise him. I should answer questions for him; offer opinions where asked. In fact, when I learned that he had been elected, I invited him to come out and visit me and to chat for an afternoon. I don't really remember anything about the conversation except that we had it. I remember that he seemed to get a lot of things wrong as president. He antagonized people a great deal without seeming to accomplish a lot by it. As far as I could tell, he had very few friends on Council, politically or otherwise. And then he started to get into conflict with Hespos, and that got worse and worse.

NORBERG: What was the character of the conflict?

ABRAHAMS: I can't really remember now, but I remember that it was there. I remember things got to the point where in the Executive Committee we told him, basically, "Clean up your act, or else." The other four of us were united on that. That was Jack Esbin, Dave Wood, John White, and myself. We were the Extended Executive Committee. So we sat down with him and said, "You know, you're doing these things that are really bad and destructive." I can't remember what they were anymore. And we said, "You have to stop. If you don't stop, we're going to take action." So he calmed down a little bit, but then he got into this conflict with Hespos, which led Hespos to resign. There were accusations of people being unprofessional, and all that kind of thing. I wish I could remember more of the details of that, although it probably doesn't belong in the transcript, anyway.

NORBERG: Probably not. 
ABRAHAMS: It was very personal and very bitter. Although, there were some questions as to whether Hespos really should stay around for much longer, anyway, this particular issue accelerated his departure in a rather awkward way. Hespos was a very interesting guy. Like the other ACM executive directors, quite smart, and quite intelligent. My own opinion of him was that he was a superb diagnostician, but not a great therapist. He was very, very good at determining what was wrong, but not quite so good at figuring what to do about it. His remark about "perhaps the dogs don't like the dog food" to explain ACM's difficulties in maintaining membership was a good example. So anyway, I guess there was a lot of conflict between Kocher and everybody else. I mean unlike the Goldberg conflict between me and Adele, I think he had very few allies, as well as I can remember. He really was quite a lone wolf. I think after he was president, he kind of faded out, and I haven't heard anything of or from him since.

NORBERG: Do you know what his specialty was in the field?

ABRAHAMS: He was some kind of a data processing consultant. He certainly was no kind of academic. He was a very pragmatic sort of guy. I don't remember too much about him except that he just antagonized people, and not just some people, most people.

NORBERG: All right, let me bring this section of our interview to a close on a very happy note. Let me ask you what you believe was your most important legacy as an officer of ACM.

ABRAHAMS: That's an interesting one in itself. If I had to say it, I would probably say I kept the ship moving in the right direction, and maybe moved it a little faster. I may think of more things than that, but some of that has to do with, ultimately, what do ACM presidents do in general. If you ask what's the best a president has ever done, how much difference did it make? And maybe it's because I just don't remember enough. In fact, Dave Brandin said something similar. Don't let the ship sink. Don't be the captain of the Titanic. Keep the ship going. If you keep it going and make it go a little faster, you've been a successful president. There are other things in my legacy, which were not when I was president. When I think of my best accomplishments, it was probably the things that I did in SIGPLAN. If I had to pick out two things, it would be that symbol manipulation conference and the publication of the Ada language definition because those were really unexpected and made a difference. They were the sort of thing that just doesn't normally happen, especially the Ada thing. Under any other circumstances, here you have this language definition coming out. This community is interested. Six months later, they see it. Not four days later.

NORBERG: Yes. And that does take a long time sometimes.

ABRAHAMS: To make something happen that fast was really something I was proud of, and still am proud of. I suppose the other thing is, maybe I inspired people a little bit in the sense of using the bully pulpit well.

NORBERG: Well, let me give you another chance to use your bully pulpit, even though you're not the president of ACM at the moment. Is there a role to be played by past presidents of ACM, either singly or collectively? 
ABRAHAMS: Probably there is, although they've never really been called on as a group. I think it would be very interesting to have a meeting of past presidents and to pose a few questions about ACM. Where is it going? What should it be doing? And just have a series of, I don't know, essays, possibly, or something like that on that subject. Now, considering the fact that people go off in all kinds of different directions, and even some have their marbles more than others. [Laughter] And you've certainly seen this in all the interviewing you've done.

But I think that sometimes, when you put together a lot of things that none of which is quite right, the errors may cancel each other and the truly good ideas may emerge. I think there is a lot of collective wisdom there. There's certainly collective wisdom, I think, on how to be president. But I think there's collective wisdom on more than that because everybody has his little bit of the picture. The president probably sees more of the picture than anybody else. Another thing is that the more recently you were president, the better you remember it, so there's something to be said for that, too. But maybe the longer ago it was, the wiser you are. That's the other side of it. I'm wiser now. I don't remember as much.

NORBERG: Do you think there are any obligations that the past president has to the association?

ABRAHAMS: Not really. Certainly, nobody's ever been called on it, as far as I can tell. I was actually asked to do a couple of other things. I was, for example, on the Fellows Committee for a while. Peter Denning asked me to work - although, this was a paid consultancy thing —on his work on preparing documents on computing as a profession. I did some work for him on that. I was quite flattered that he asked me to do that, but I think it was partly a measure of the fact that he respected my ability as a writer, as I respect his. He and Dave Brandin are the two people I learned the most from, which is interesting because I also had a lot of disagreements with them. But I still have to give them a lot of credit that they taught me much. So I don't know that I can say much else about past presidents.

NORBERG: Can you say anything about what past presidents should not do?

ABRAHAMS: Well, they don't have the chance to do much harm once they're off Council, unless they come back. And I can't remember any that did. There may have been some. Well, Grosch did.

NORBERG: Yes, he came back for a while.

ABRAHAMS: Which is a bad example. [Laughter] Herb Grosch is probably the best example I can think of. [Laughter]

NORBERG: Okay, Paul. I think we'll call it quits for today.

\section{Session 3, Tape 1, Side A}

ABRAHAMS: I thought maybe it would be useful to add a couple of little memories. Actually these are before I was president. First of all, my time in the Soviet Union, which was very interesting, and the situation that where I was at Moscow State University was interesting 
because Jack Schwartz had arranged for me to go over there, and his buddies were all in the math department. And I found that they were wonderful people, I really liked them, we got along very well, but we had virtually nothing in common professionally.

NORBERG: Why is that? What sort of math were they doing?

ABRAHAMS: Theoretical. Pretty much on the theoretical side of mathematics, but they knew virtually nothing about computers. And so the people I naturally tended to talk to were very different, and the other interesting distinction was that by and large the mathematicians were non-party, while the other people were very much involved with the party. So it was a case where personally I got a long with one group, and professionally I got along with another one.

Another memory I have of that time was the state of computing. And an interesting indicator of it was the punch cards they used. The punch cards we were using over here had rounded corners. The ones they were using were made from lower quality paper stock, and did not have rounded corners. The result was that they were forever jamming in the machines. You know, a typical kind of problem they had in the Soviet Union in those days. In fact, I remember that I'd decided that there were two mottos that really applied there: Nye rabotaye and Nye chevo-It doesn't work, and it doesn't matter. [Laughter]

Another thing that came back to me, I was thinking about my early days at ITT where I was a little, you know, I was skeptical of a lot of things, and it was my first encounter in a way with a certain kind of corporate culture. And so I wrote this memo as a joke called "The Weak and Strong Progress Theorems". I don't remember which one it was, but one of them was kind of a mathematical demonstration that in any project, as you increase the frequency of reporting, you decrease the amount of productive work accomplished, until if you do nothing but reporting, then you accomplish no useful work.

NORBERG: I remember that from Engineering Research Associates, where the Navy required all sorts of reporting on almost a weekly basis. And if you go through them you see there's not a lot getting done until the end of the project, and you can sort of see that they did accomplish something.

ABRAHAMS: Oh, that reminds me of another little theory I came up with. This was not a project I was involved in, but ITT was doing something called Navy Service Failure Analysis, of the rates of failure of various parts that the Navy was using. I remember people used to have to fill out these forms on things that failed. And I came up with a theory, the parts with long numbers would fail rarely.

NORBERG: How did you come up with that?

ABRAHAMS: It's harder to fill out the forms, and even harder to fill them out correctly.

NORBERG: All right, let me pick up with a couple of things myself, not so much from yesterday, but things that I missed on Monday as well. And that is this application of LISP to sequence predictions.

ABRAHAMS: Yes. 
NORBERG: I mentioned this to you just before I left yesterday about the comment you have on page 13 on this work. "At a relatively early stage in this work it was realized that more sophisticated methods of resource allocation were needed, however the programming tools were not available." Can you elaborate on that?

ABRAHAMS: Do you have that report there?

NORBERG: Yes.

ABRAHAMS: Because then if I look at it, I might be able to. I have it downstairs somewhere, but if you have it that saves a little time. And what page was this?

NORBERG: 13.

ABRAHAMS: Let me look at the context. Yes, at least while the rest of it told me something an apparently important aspect of this was being able to tell how much work you're using in a particular worker process, how much effort are you putting into it. And the problem for that is you need to have some way of telling how long something has been running and incorporating that information. And apparently that was something that was not available at that point. Basically a measure of efforts, so there was no really good way of getting good measures of effort that you were putting into one of your working processes.

NORBERG: Now would this have been solved by using another computer?

ABRAHAMS: Not at that point, I don't think. The monitoring facilities that were available at that point were just pretty weak.

NORBERG: While you have that in your hands, the next page at the bottom, I think, starts the acknowledgements. Can you identify the people who are there more than just their company, because that's clear from your statement?

ABRAHAMS: Yes, but looking at this, there were two things. They let us use their system.

NORBERG: This is system development.

ABRAHAMS: Right. They had this time sharing system that you could use remotely. In a very awkward and expensive way, but you could. Basically you had to have a long distance call running in the days when long distance calls were not cheap. And there were also specific people, Stan Kameny, who also got involved with the LISP project, and the same thing with Clark Weissman. In fact, all three of these people, Bob Saunders was working for III at the time, which is kind of an interesting company, then it got involved with programmable film readers, which is where they got all the money. And then because Ed Fredkin was interested in LISP and things like that, particularly because of his tie-in with Marvin Minsky, they expanded into the LISP II business. And they had a lot of expertise. They had people like me, they had other people who knew LISP who were involved with LISP, and so this gave him quite an in at SDC.

NORBERG: Are there any of the names there? 
ABRAHAMS: Yes, Malcolm Pivar. He was a very interesting and very strange person. Basically he was mentally somewhat unbalanced and he ended up institutionalized, if I remember right. And he hadn't quite gone off the deep end back then. He was one of these people who has a lot of smarts, but could never get anything done. Ed Fredkin recognized his talents and figured out how to get some useful things out of him. But he was really mentally somewhat off. I don't remember exactly in what way or what came of him, but I remember he had a lot of problems. I remember Elaine Gord, but I don't really remember much about her. And I don't remember Mark Finkelstein at all. I probably knew who he was, but I can't think of him now. And Clark Weissman is the one I mentioned that's at SDC, was the one who was something like the guitarist for Pete Seeger or something like that, so he had had this other totally different career.

NORBERG: Okay, the one thing that we have not talked about since Monday is your continuing career at NYU. While we were discussing AFIPS I was avoiding your other life, as it were. And so now I think we should pick up on that. And as I recall, you were there until 1980.

ABRAHAMS: That's right.

NORBERG: What was going on at NYU between, when did we stop, somewhere around ' 68 or '69 up through the 1970s?

ABRAHAMS: Well, my big involvement, and virtually the only thing I really was working on was the PL/I stuff, the activity on the PL/I standards, the continuing improvement of the PL/I compiler, which I really felt I had climbed the mountain in writing that. As I may have mentioned, you know, part of the reason I did it was the feeling that it was a challenge. If you could compile PL/I, you could compile anything. It was a huge language with many, many ramifications; many things were, you know, not even well defined.

NORBERG: Can you remind me again why you picked that as a task to do?

ABRAHAMS: Well, I was very interested in compilers, and I figured this was, in a way, a good test of how to push the technology. And it did lead to a couple of papers. The fact that the syntax of PL/I was so weird. For example, how did you deal with that? And I came up with some kind of neat ideas for how to do that that had other applications beyond that. The notion of oracles in parsing was something I came up with, basically an oracle would make predictions about how things would go. So if you couldn't really do these things directly using the normal methods, you would just race ahead, look at what was coming in, and then feed the information back to do the right thing at an earlier stage. The big emphasis that had been made, at that time that I remember in the department, was Jack Schwartz and his work on SETL software. It was a set theoretic programming language, which I always thought was a little bit unreal. Jack was and is a very forceful person, and he really was able to push that pretty hard. And got grants because he had a lot of friends over at NSF.

I remember also, I think it was around that time, there were a few people who came through the department. One of the most interesting was Susan Graham, who subsequently went out to Berkeley, of course, but she was at NYU for a few years and I became friendly with her there. And then there was Robert Dewar, who I also became friendly with. He also, like me, 
was a programmer at heart. A very clever guy. And he got involved in the SETL project too, because kind of that was the thing for most people to get involved with, though I managed to steer clear of it. And when I think about what was I doing, well basically I was doing PL/I things, PL/I and compiler things. I don't remember that I was doing terribly much else, though I may have been; it just doesn't come to mind that I was.

NORBERG: Did you start doing any consulting at that time?

ABRAHAMS: Yes, I did some consulting, most of which was really freelance programming of a sort. I remember there was one company whose name I don't remember, they had a contract with a naval architecture outfit that was working in the World Trade Center at the time. The one time I actually spent a fair amount of time in that building. And I remember that they had a program that was written by some student or something for them. It was an amazing program in a way that it could be so badly written. And among other things, I remember that it did a certain amount of its calculation by writing information out to tape, and then bringing it back in again, which was a very slow process. Then I quickly realized that if I just constructed the right tables, I could do the whole thing in memory much simpler-avoid this whole inflated input/output mechanism, then, on top of that, make it run ten times as fast. And so I was really pleased with how I managed to strip that thing down. I remember back when I think I did some other consulting for them with some company in Stamford. I don't remember offhand what the company was.

\section{NORBERG: Xerox?}

ABRAHAMS: It wasn't Xerox. I keep think ITT, but I don't think it was ITT. I just don't remember who that was, but I do remember commuting up to Stamford for a while to work on that. Basically, they were a contract programming outfit, and I was very good at that sort of thing, so that's what I did.

Speaking of consulting, that reminded me of another-- I guess I did tell you the story of my summer job at American Bosch Arma, and how that turned into the Univac 1103 stuff. That was kind of interesting.

NORBERG: The Univac 1103 or the ERA 1103?

ABRAHAMS: Both. It was renamed when Univac bought out ERA.

NORBERG: I don't remember whether they were renumbered or not, but I know that ERA didn't build very many of them.

ABRAHAMS: That's right. It was the first and the last machine I ever saw that had water falls. [Laughs]

NORBERG: Isn't that true of the Cray machines?

ABRAHAMS: I don't think so, but it could have been. 
NORBERG: There was one at the university I remember where you could see the coolant circulating through the memory tank or memory cylinder-whatever you want to call it.

ABRAHAMS: I don't really remember much else of-- I probably did some.

NORBERG: Well, you did some with IBM for about four years, apparently, at the Watson Research Laboratory.

ABRAHAMS: I guess I did. I don't remember. Do you have any notes about that?

NORBERG: No, I don't.

ABRAHAMS: Let's see. I remember teaching a course on operating systems at Bell Labs. I did that. I remember that. Now that you mention it, I remember traveling up there, but I can't remember why I was traveling up there, so that part just escapes me.

NORBERG: Well half of it was during your presidency, so time might have been a factor here.

ABRAHAMS: That is a different part. Let's see. I just don't remember the timing, but I did teaching about PL/I at IBM, and I also got involved in writing-- they were trying to producing a standard PL/I compiler themselves, or to standardize their compiler, and so they needed a manual, which was different than the one they were using previously. So I got involved in writing that, and it turned out writing manuals was something I was very, very good at. So that's what I did. I forgot about-- I was thinking of earlier, but I was actually doing a lot of that sort of thing. It was actually a pretty good income source for a while.

NORBERG: Was that the thing that encouraged you to set yourself up as a consultant as opposed to remaining at NYU?

ABRAHAMS: No, that came about a little differently. It was more a case of I got tired of living in New York City, and I had this marvelous sabbatical year up in Hadley. One thing I forgot to mention about that year was that's when I built a harpsichord, which sits in this very room. The interesting thing about that is that I built it not because-- I mean, I like harpsichord music, but I decided it didn't matter whether I ever learned to play it or not; the important thing was building it. I'm still proud of it. It just came out beautifully. I built it from a kit, but still.

NORBERG: You're the second person I've run into that built their own harpsichord.

ABRAHAMS: Ah, who's the other one?

NORBERG: It was a professor at the University of Minnesota in art history. My wife was friendly with him, and so we toured back and forth between each other's homes from time to time. He didn't build it from a kit; he hewed all the wood himself, apparently. It took a long time, but he enjoyed doing it. And he played it well enough, as far as I could tell.

ABRAHAMS: Well, I never really learned to play, but to me that didn't matter very much, because the point was building it. I remember thinking about various analogies between building 
harpsichords and building programs. I remember there was one master harpsichord builder whose description of what it takes to make a good harpsichord was "getting enough things right"- an interesting way of looking at it.

So anyway, getting back to the IBM stuff, I remember spending quite a lot of time out in San Jose on the teaching and on the development of this manual, which also worked very well in conjunction with my activities on the PL/I standards committee. I forget when that ended, but it was probably sometime in the mid-1980s.

Oh, and there was another consulting project that I had with IBM at Yorktown Heights working with Jerry Fisher, who had worked with Jack Schwartz on a software engineering design language called SEDL, which the name that resembles to SEDL, Jack Schwartz's language. The name resemblance wasn't just a coincidence. That was a productive thing in more ways than one. I was working on the design, but I guess-- come to think of it, the part I was working on, again, was the manual, because writing these kinds of manuals became a specialty of mine.

NORBERG: At a time when manuals weren't very good.

ABRAHAMS: That's right. And so I, in fact, see kind of a link between the operettas I wrote when I was in the ninth grade and the manuals I wrote at that point. And writing has really been a kind of motif, and it shows up in a number of ways. It shows up in this kind of consulting of writing programming manuals. It shows up in the fact that I won elections at ACM because I could write such good statements. There was some other way it showed up, but I can't remember what it was now. One of the things that I think of is that since I've been living up here, there have been times that I've been quite active in writing letters to the editor of the local paper, and they tend to be very well-received.

NORBERG: What were the letters about, in general?

ABRAHAMS: Well, generally, they were about political things, mostly — sometimes local issues, but more often national issues. I mean, I think of one-- this is kind of a random thought, about the fact that people don't recognize that the nature of tax expenditures is that when the government gives a dollar in a tax break to somebody, it's the equivalent of spending a dollar, and this is not recognized at all. This is just one that occurred to me. I have a whole collection of them, and I wish I could remember more about them. But anyway, they were mostly political; a few of them were humorous. I remember one that I wrote about the misspellings in the newspaper. One that I particularly remember was when they referred to a "ferrous" wheel. I said, "That's ironic." [Laughter]

NORBERG: It sure is. It wasn't made of wood! You mentioned a couple of times yesterday and you implied it again today that you decided you liked this area of Deerfield on the Connecticut River very well after having spent some time here during your sabbatical.

ABRAHAMS: Yes, that's right.

NORBERG: Did the purchase of this house coincide with your leaving NYU?

ABRAHAMS: Yes. 
NORBERG: It did? Okay. So you preferred to live up here and do your work as need be.

ABRAHAMS: Yes, and my take on it at that point was, well, the most important thing is to live here, and then consulting is just a way to stay alive. So I've lived in this house longer than I've lived in any other house, and this has been just a marvelous area for me, even though I'm not up to doing some of the things I used to do. I used to do a lot of bike riding, hiking, skiing.

NORBERG: I used to do all those things, too, but not in the last decade.

ABRAHAMS: Well for me, it's more recent than that. I may be able to get back to some of them, because I had both of my knees replaced almost exactly a year ago.

NORBERG: Maybe we'll talk about that offline.

ABRAHAMS: But I can tell you it was a very successful operation. I'm a poster boy for this particular surgeon.

NORBERG: All right. Now how did you become involved with TeX?

ABRAHAMS: It's actually pronounced "tech". That brings up the other connection about writing, which is writing books. That came about because Peter Gordon, who was an editor at Addison-Wesley met me at ACM, and basically, I said, "You know, I would like to write a computer book of some kind. What do you need?" He said, "We need a book on TeX." So I learned about it and wrote a book on it with Carl Berry and Kathy Hargreaves. And writing that was very interesting. First of all, I got quite interested in typography. I got very interested in the mechanics of writing, and even the mechanics of English grammar. I remember that we used to get into terrible arguments, you know, about what type-face to use where and this kind of thing, because we had very, not that different taste, but different enough. So you know, we had a lot of-- we all had strong feelings about this kind of thing, and we did this book in TeX, and so I did the book design - what the headings look like, everything. And I was involved in that, because they both knew a lot more about TeX than I did. But I did the actual writing, and I pretty much had an agreement with Peter that I would really have control over the copy editing, and AddisonWesley did a copy edit which turned out to be almost useless. So basically, I fixed the things that really needed to be fixed, and then the book got published. It was quite well received. The next book I wrote, Unix for the Impatient, got even better reception, and that's still in print and people are still buying it. I refined my ideas about how to write books in that one, and that one I did with Bruce Larson, whose background basically was, he was just a Unix guy, and I needed somebody who really knew Unix better than I did. So writing books turned out to be, you know, it was a nice, little income source, and it also was very satisfying to do that.

NORBERG: Now, I only know about three books. Were there more than that?

ABRAHAMS: No, that was it, basically. I had planned to write a couple of others, but they never actually happened. One of them was on XML; another one was on OS/2; and then there was a third one on Linux, which has been a great interest of mine over the last maybe five, ten years. 
NORBERG: Let me just stop you there for a minute. When you published TeX with these colleagues of yours it was in 1990s, just when you were coming off your post as past president.

ABRAHAMS: Right.

NORBERG: How did the activities as past president play into this, if at all?

ABRAHAMS: Not much, as well as I can remember. It was just two different things I was doing. And after I was past president, I pretty much, not entirely, faded off the scene. I was involved in this project with Peter Denning, which you may have heard about of computing as a profession, trying to get grants and stuff.

NORBERG: I'm coming to that.

ABRAHAMS: Basically, he knew my writing abilities, and he was looking for somebody who could write this sort of thing, and I did.

NORBERG: And those were published in Communications?

ABRAHAMS: I believe so.

NORBERG: For the most part?

ABRAHAMS: But basically, the idea was to use them to bring in grant money for ACM. I don't know whether it actually did bring in-- it certainly didn't bring in much money. And some of it, I didn't even really agree with, but I felt, well, that doesn't matter; I'm a hired gun, herelike a lawyer.

NORBERG: Tell me about your association with Peter Denning at this time now.

ABRAHAMS: Well, it was pretty-- if we didn't get along, then I never would have been asked to do this. So we did get along pretty well. I think that, you know, even though we had had our disagreements in the past, we both respected each other. And I was kind of amused about the political aspect of it. But he never quite took the bait on that, you know. It was as though he didn't want to talk about the fact that we had such different political views - one thing that was just kind of interesting.

NORBERG: Have you looked at his website on the great principles of computing?

ABRAHAMS: No.

NORBERG: Okay. Then you didn't have anything to do with it?

ABRAHAMS: No, I didn't.

NORBERG: It's a very interesting website, and I questioned him a great deal about it. 
ABRAHAMS: I should go look at it.

NORBERG: It would be entertaining, if nothing else. Many of the things that he's calling principles, I just see as algorithms, and we politely disagreed on that during the course of the interview. Okay, fine. Were you involved in any other non-ACM volunteer work at this time?

ABRAHAMS: Later on I was, but it was a very different sort of thing - the Town of Deerfield. I spent quite a bit of time. I first got involved with the Sewer Advisory Committee. How did that happen?

NORBERG: Pray tell.

ABRAHAMS: This probably tells a little bit about me, this story. Deerfield has basically a downtown area, and then rural areas like this. And the downtown area has sewer service, and the areas like this don't. Well, how are the sewers paid for? They were paid for, basically, by the town - they came out of the town taxes. I and a few other people, when we saw some of the expenditures, were not terribly happy about that. And so I started to complain. I got a resolution through a town meeting. Deerfield town meetings and New England town meetings in general are interesting. Deerfield is a good example of them. So I actually brought an article to the town meeting - my petition - saying, basically, that the sewer expenditures should be paid for by the sewer users. I made what I thought was a rather elegant presentation on the subject with overheads and things like that, and a lot of humor. My experiences at ACM helped me do that, I think, very well — being very, very polite, and even complimentary to the people that disagree with me, saying that their arguments were significant and had to be taken seriously, and I addressed them one by one. They felt a little blindsided by this, because I had been out canvassing votes for this thing and getting people to the meeting, and they didn't know that I was doing this; they just never heard about it. I was told subsequently by one of the selectmen, you know, "Why didn't you tell me you were doing this?" The truth was, I wanted to get it through the meeting, and I succeeded. So I got involved with the Sewer Advisory Committee and learned a lot about sewers I had never known and wastewater treatment plants and things like that, and wrote a number of reports on that thing for the town.

I remember writing reports on this and all kinds of stuff as a member of the advisory committee, and how to deal with the problems of inflow. The sewer plant was getting too much water, and they couldn't handle it all. So the technicalities aren't really all that important or interesting; the main thing was I did a lot of writing, and I also did a certain amount of politicking in connection with this. So in many ways, this is kind of a continuation of stuff I had done from ACM with a very different context.

NORBERG: Is there any carry-over from that? Have they decided to put sewers out here?

ABRAHAMS: No, they didn't, and they never will. There was a carry-over, which is now the town finances its sewers differently. When they need something new for the sewers, the sewerusers pay for it. That wasn't how it was, but it is how it is now.

NORBERG: Seems fair enough to me. 
ABRAHAMS: I thought so, too, and so did a lot of other people. People called me up and thanked me for doing this. It made me feel very good. That led to more of an interest of what was going on in the town, which led to another activity for the Town of Deerfield, which was helping them get a computer network set up, working on all kinds of aspects of that — even going in and doing wiring, learning about telephone-- not switching, exactly, but the panels, how those things are organized, and the tools that you use in doing telephone wiring. I actually got behind the walls and that kind of thing to run wires. I had done some wiring in this house, so I knew a reasonable amount about wiring, although I couldn't really run wires very far through the walls. I did a lot about the connections and the connections to the panel. So basically, I got them onto the Internet, and got all the computers talking to one another and a whole lot of other things like that. That also led to being involved in setting up the town website.

NORBERG: I looked at that site. It's very nice.

ABRAHAMS: It's pretty primitive, I must say, but still... It's going to be replaced.

NORBERG: It's informative. That's what counted with me.

ABRAHAMS: So I mean, the other ones are much better, because I never really learned about website construction. Plus, there are a whole lot of things about how you get the information, how you keep it up to date. I was involved with other things in town computing, setting up a backup server for them.

NORBERG: They must have loved you.

ABRAHAMS: Oh, yes. They still do. I did this all as a volunteer. The only problem, sometimes, is they have their own ways of doing things. I remember getting involved with the assessor's office and how they were handling things. Basically, I was there computer guy, and in some ways still am. So that consumed a fair amount of time, but it was time I had. You know, I at a certain point - which was, I guess, about almost ten years ago-I went on to Social Security, and I had some pension money from NYU, and I reached point where I said, "Well, I don't need to do anything I don't want to do." I don't feel that I have to prove myself professionally anymore, so I'm going to devote the rest of my life to enjoying myself.

NORBERG: I feel the same way.

ABRAHAMS: You didn't come out here because you had to; you came out here because you wanted to. You could have said no. You do it because you like it.

NORBERG: Yes.

ABRAHAMS: Well, very little that I do now brings in money. Every once in a while-- I mean, I've done, for example, just fixing people's computers. My interest in computers has not faded in the least. I spend a lot of time just setting up things in this very house. Computers take a lot of maintenance.

NORBERG: Yes, they do. 


\begin{abstract}
ABRAHAMS: One of the things I realized is, when you work with computers, you spend an enormous amount of energy - probably more than anything else - on fixing things that aren't working the way they're supposed to, rather than doing new things. So this work with the Town of Deerfield has been very interesting. I've learned stuff from it. I'm considered now one of the really important people of the town, and I feel in that way I've kind of gotten myself into the community in a nice way. Also, one of the things... you know, basically, I'm an introvert, and I always have been, and one of the things I occasionally thought about was, when you look at the kinds of things that people do for social service, Peace Corps, things like that, most of them are designed for extroverts. An interesting question is, are there ways that people who are introverts, that have a sense of social obligation, who basically don't want to have that much to do with people and are a little shy, maybe - are there ways that people like that can be useful? The answer is, absolutely, because they know so much technical stuff, they can be enlisted to do technical things, and they can just kind of sit off and do these kinds of technical things, and they don't have to interact a lot.
\end{abstract}

NORBERG: I would suggest that that's true of a town the size of Deerfield and some of the other towns around here, but when you get into a city like Minneapolis, the size of that, with 700,000 people, it's pretty hard to stand out by doing volunteer work.

ABRAHAMS: Oh, yes, I can see that. A city that big, there's probably not much room for volunteer work.

NORBERG: Yes, and there's enough money to pay for people to do the task.

ABRAHAMS: I was thinking of this much more generally. You could almost think of something like a Peace Corps for computer nerds, and there's certainly enough room for that kind of thing - helping people in all kinds of contexts with computer problems. There's probably other things besides computers where this applies.

NORBERG: Haven't companies like Best Buy and Circuit City tied that up with their Geek Squad and Foxfire and so on, where they go on to do the kind of solutions you're talking about, and, of course, get pay for it?

ABRAHAMS: I'm kind of thinking more of the social service, charitable things, which Best Buy doesn't do, because they don't get paid for them.

NORBERG: They're not very charitable. I can agree with that.

ABRAHAMS: I should also mention, you know, when we were talking about the writing, because that's been kind of a motif in my career, another interesting bit of consulting which you probably never heard about at an IFIP meeting, which I got to because of being president, I met a Japanese professor who was working on something he called super-distribution. Basically, it was a hardware method of handling intellectual property stuff for software. And he was writing papers on it, but his English was very poor and he needed help. So that has led to a continuing relationship which is still there. Basically, I was his editor, and as I sometime described it, I would translate his papers from "Jinglish" to "English". And it led to several trips to Japan and 
giving some talks over there, too, about various computer-related things. The fact that I had been president of ACM made me an interesting speaker. I spent a couple of weeks at the University of Tsukuba working with him. He also lent me a car. I still remember that, because I couldn't get used to driving on the left. So I didn't use it very much.

NORBERG: It was nice of him to supply the car, though.

ABRAHAMS: Oh yes. Mostly, it sat in a parking lot. So that was an interesting time. And interesting also that they're-- you know, I tend to be somewhat of a night owl. Technically, I get up about nine or ten and then go to bed at maybe one or something like that, but people there don't show up in the lab until noon or one, and then they would be working there at one or 2:00 am still. So they tended to have my patterns, only even more so.

NORBERG: That's a surprise to me, actually.

ABRAHAMS: Yes, but that's how it was. So I've been doing a lot of things. I've had acknowledgments in his papers. Most of what I've been working on has been creating Wikipedia articles for him on super distribution. So it's not been a major income source, but it's brought in some money now and then. I feel that at this point, my economic life is stable enough so that it doesn't matter what I do. It's a very nice place to be. I'm reasonably healthy. I'm not perfect, but good enough. I still have my marbles.

NORBERG: Well, that's clear.

ABRAHAMS: In fact, when I think about things I do to keep my mind sharp, one thing I got more into was crossword puzzles. You know, I do the New York Times ones regularly, but the other ones I do are the Cryptic ones. I don't know if you've ever done those.

NORBERG: Those are too tough for me.

ABRAHAMS: Well, they're too tough for $90 \%$ of the world. They were too tough for me for a long time, but like many things, you gradually build up your skill at them.

NORBERG: I used to try to do the ones in the Times in England. I couldn't do it.

ABRAHAMS: I probably couldn't, either, because there's so much British culture. The ones I do are Harper's Magazine, and the New York Times sometimes has them. The Atlantic used to have them; they don't have them anymore.

NORBERG: I read The Atlantic very rarely at the moment, but I used to read it quite a lot at one time. The articles are too long now. I don't want to pay that much attention to issues that I'm not involved with. But reading the Times each day is an important one. [Break]

NORBERG: In ACM, there's been a series of curricula developed, and it seems, as I said yesterday, that this whole process of defining or at least finding metaphors that you can use to describe what computer science is seemed to change over the years. The first curriculum was 
pretty straightforward about hardware and software. The second curriculum, there was a whole series of new things added, and it had to be reconstructed as a model. The third one I thought was really not very good, the 1988 one. I remember my colleagues discussing it in faculty meetings and so on, and in that series of discussions the result was that you had to go way out of your way to define what it is you were doing, and then bring them back to some standard way to describe how to do it. That, it seemed to me, was back to the " 78 curriculum. I understand that the 2001 curriculum, or whatever it is called, is really a very good one. Now, were you addressing this question when you wrote this piece on "What is Computer Science?"

ABRAHAMS: No, in fact I see them as almost unrelated. I think the curricula people would be hard-put to relate to mine, if you really asked them. That was an area I never much got into. There were people who did it, and they did it, and I didn't do it, and I was glad to have them there. One of the feelings I often had about running things, you know, as president, was, thank God for the people who do the things I don't to do or am not competent to do. So there were areas, which as long as there was somebody reasonably competent in charge of them, they were running on their own, as far as I was concerned. It was only if there were problems that I needed to deal with it, and so I was very happy to see them shine. Which I think is probably generally a good management tactic anyway. So there were certain areas - and I imagine that was not the only one-where there was a lot going on, and I sort of vaguely was aware of it. The main thing that I was aware of was that it was running on its own. So I could concentrate in the things I was more interested in, cared about more, and was better at.

NORBERG: Why "What Is Computer Science?"

ABRAHAMS: Well, that was kind of an intellectual issue. It's not clear how much the definition of it really influences what gets taught. It's more almost a philosophical thing. It may conceivably influence things like funding agencies at some point. If you ask me, "What difference does it make," I might have a hard time answering.

NORBERG: Well, I wasn't going to ask that question, but in there, there's this big science versus little science model, and I was trying to understand where ACM fit into that in your thinking. Is computer science big science?

[Phone interruption]

\section{Session 3, Tape 1, Side B}

NORBERG: So there's this business of big science, little science. And how do you classify something like computer science? And where does ACM fit into that, if it does at all?

ABRAHAMS: I mean certainly the theoretical end of it is little science; it doesn't require much equipment. On the other hand, there are enormous computing projects - particularly in scientific computing. People build very big and expensive computers. So there are parts of it that are both. I don't know if physics is as much little science anymore. I imagine if you get theoretical enough, maybe you don't need a lot of lab money, but...

NORBERG: String theory might be an example of that. 


\section{ABRAHAMS: Yes.}

NORBERG: Okay, I was trying to fit this into the other articles that you've written on the education of computer science, which I saw in some of those technical contributions - the map color problem; two programming problems; software engineers, what do we need them for? That wasn't the subtitle, but that's what it came down to. These things all seem to me to be a concern of yours as to fitting in mathematics, maybe at the...

ABRAHAMS: Or over-doing mathematics. In fact, it reminds me of something else which related to a small argument I had with Peter Denning. You probably know Edgar Dijkstra.

NORBERG: Oh yes. We interviewed him some years ago.

ABRAHAMS: Well, I felt that he had done a couple of really good and clever things early in his career, and then went off the deep end, as far as I was concerned. Communications of the ACM had this whole issue basically devoted to Dijkstra and commentaries on what he had done, only one of which was even mildly critical. He wrote a paper that was the lead-off called "On the Cruelty of Really Teaching Computer Science", and I said, "This is bull, front to back." Now, I wasn't the only one with a really cynical view of Dijkstra. The other one who did, who wrote a scathing review of his book - only a few paragraphs long — was Robert Floyd out at Stanford, who was a very distinguished guy. Incidentally, I also went hiking with him in the White Mountains early in my career - another one of these interesting little connections. So I wrote what I still think was an absolutely masterful letter to the editor about this-fairly long-and about what was wrong, starting with the English-you know, the fact that the English was so confused, even the title; what does it mean? I said it could mean several different things, and none of them seemed to be what he was saying. Nor did he ever refer to the title once he got into article-So he never justified the title. I mean, was it cruel to teach computer science the way it was being taught, or is it cruel in general to teach computer science, or what? It was a totally meaningless title. So I wrote this marvelous diatribe. The centerpiece of it was a specific explanation of a bug in one of the programs that he had proved correct; the program that he claimed correct was not correct. And I said, "You know, if somebody claims they can walk on water, and then they fall in, they really deserve to be called on it." I had a lot of fun writing that thing, and I still remember that at the very end of it, I said, "You know, if you're going to be full of invective, at least let it be good invective, you know - not this kind of shrill carping--no reference to Richard Karp intended." And then the last thing I said, I gave some examples of good invective versus what he had, and the very last one was from Golda Meier, who said, "Don't be so humble; you're not that smart." [Laughter]

NORBERG: Did any of your teaching at NYU influence you in writing any of these other books?

ABRAHAMS: Let me finish the story. Peter Denning said, "I'm not going to publish it. You're angry. You're angry at him, so I shouldn't publish it." So it never got published. But I think it was one of the best things I ever wrote, even if the world never saw it. He wouldn't publish it.

NORBERG: That doesn't seem right. 
ABRAHAMS: Well, I didn't think so, either, but he was the editor at that point. It was also a little long. I don't know if you would be interested in having a copy of it.

NORBERG: I would like to add it to the Dijkstra file, if nothing else.

ABRAHAMS: Yes. Before you leave, I'll run off a copy of it.

NORBERG: But now my question: did any of your teaching experiences at NYU influence the writing of these pieces on the education of computer science?

ABRAHAMS: Good question. I certainly did have my frustrations in teaching, which was part of the reason I left NYU. The department, as I remember, had a pretty good balance between theory and practice. I designed a couple of courses. I remember one on operating systems. It wasn't principles. I don't remember what I called it, but it was the pragmatic end of operating systems - basically, all the things you need to know about running operating systems when you're writing programs. And somehow it got lost with all the theory. Maybe it was operating system practices, or something like that. But anyway, that turned out to be a very useful course for a lot of people. I guess the one thing I had was kind of an appreciation of the gap between theory and practice that... so much of the theoretical work seemed to just not have anything to do with anything. It was really just almost abstraction for its own sake. Some of the theoretical work was applicable, but I wasn't even sure that, you know, by mathematical standards, it was all that good. What was the question?

NORBERG: The question has to do with, did your teaching influence some of the articles that you wrote that were about teaching things to young computer scientists. Or old computer scientists.

ABRAHAMS: I couldn't really tell you how it was involved, but I'm pretty sure it did, because I had a lot of teaching experience. I had to have learned something from it.

NORBERG: Well, what I was leading toward there is that when you published that piece on "What Is Computer Science", you used mathematics as the example of the theoretical side of computer science, which made it a science - made computer science a science — and that was a legitimate model to use on explicating on what is computer science.

ABRAHAMS: That is a question that's haunted the field for a long time, and still does. I guess what prompted me to write it was the feeling that people didn't seem to understand what it was, and the whole name was wrong. What does automata theory have to do with clickity-clackity computing machines? Very, very little. But yet it somehow seems to be relevant, and so computer science is the wrong name, because it involves-- the real thing is not computers, but computing - the processes. So I was trying to say, what is-- you know, I certainly knew about curricula. I knew that-- in fact, if you ask how it influenced me, that's probably the answer. I knew the scope of the things that people called computer science.

One way to look at this sort of thing is it's an historical definition. You can say, "Well, what are all the people doing that they say is computer science," and look at this big assemblage of activities. Then say, "What are the common threads?" Instead of starting with the theory- 
the definition - start with the thing you're defining, and say, "Well, is there a definition that brings this all together?" And I thought I really had it, and I still think I had it. That's why I liked "computology" so much, because it's an -ology, not a science. So it gets rid of the name "science". I was really impressed by what Max Goldstein said, that I mentioned about "anything with science in its name isn't a science". And what is the theoretical side; what is the practical side; how do they relate? There's a model in chemistry; there's a model in mechanical engineering. What is the difference between chemists and chemical engineers? What's the difference between physicists and mechanical engineers? It seems like something like that is going on in computing, and what is it? And what is the underlying science? If chemical engineering has chemistry, and mechanical engineering and electrical engineering have physics, what does computing have? And the answer is mathematics, because physics defines the underlying reality of electrical engineering and mechanical engineering. Chemistry defines the underlying reality of chemical engineering. So what defines the underlying reality of computing? And the answer is mathematics. It can't be anything else. There's nothing physical going on; it's pure logic.

NORBERG: Well, when I think of things like chemistry and physics, and how they came about to get their current names and their current divisions of subject matter and so on, I think that from the time of Newton, for example, when we were talking about natural philosophy, until probably the middle of the $19^{\text {th }}$ Century, when people like Thompson come along and they're redefining things there, and the engineering part of it, the building of instruments and that sort of thing, is left to the side. It gets done just like computers get done. The theoretical part is a way of bringing all this information into a series of simple statements. I don't mean simple in the sense that they're almost meaningless, but simple in the sense that $\mathrm{E}=\mathrm{MC}^{2}$ is a very important description of what's happening in atomic physics. Now all of that took 150-200 years. Why can't we just say that computer science will change its stripes as it needs to? There seems to be a rush to judgment in the computer science field. Since 1945, there's been a rush to judgment. That's why the AI people get into so much difficulty, as far as I can see. Is this something we can put off as a definition until some future time, do you think?

ABRAHAMS: Well, you know, it's happened. People are always defining it, of course, and they probably always will. The very fact that people have such definitional problems is in itself a symptom of something - of some uncertainty, of an unsolved problem. I guess when you look at physics, people were doing engineering of one sort or another long before Isaac Newton came along, and mathematics at one point, I guess, was a very practical science, because one of the main aspects of it was geometry. People were always doing things with geometry. So you can look at, how did the science relate to the technology. I guess I don't really know enough about the history of chemistry and physics, but it was happening. In computing, the applications came long before the science, so the people with a theoretical bent started to develop it. There were other independent things like Chomsky, who as far as I know, had no particular interest in computers, it seems like. But what he did with context-free languages turned out to be the foundation of a whole branch of theoretical computer science. Then there are things that are sort of in the middle, I guess, like algorithm design, where the algorithms can actually be quite practical, but yet the design of them, the testing of their efficiencies is pretty much a theoretical enterprise. 
NORBERG: So I don't see the computer scientist having anything to worry about here, and worry about in the sense of why they have to have a definition, which isn't clear in embodying everything in the field.

ABRAHAMS: The answer is that we've gotten along without it, and we probably still get along without it. It's irksome, may be one way to describe it - the fact that you're doing this; you don't have a good definition of it; people don't agree on the definition. Peter came up with his definitions, which I didn't agree with, because I thought-- I don't remember what he said, but I remember I felt I really had it. You know, nothing that I've seen has indicated to me that computology is the wrong name, or the view of mathematics as the underlying science of computing is not the way to see it. Maybe people never really took me seriously.

NORBERG: I'm not going to suggest that, but when I think of things with the -ology behind them, I think of cosmology, for example, in astronomy. A great deal of it is the attempt to fix what you learn by observation into some sort of classification system or some sort of real time system that can be observed and you know how to observe it. And nobody really talks about cosmology except cosmologists. The rest of us don't. But we may talk about astronomy all the time. That's why I see this as probably not leading to an -ology in the end. But I could be wrong. I don't know a lot about this field anyway.

ABRAHAMS: It reminds me of one of my favorite made-up words, which is "metatology" the study of essence in full generality. So what is the derivation of that? Well, the prefix is meta-, the suffix is -tology, and there is no root. [Laughter]

NORBERG: While we're on this subject, what do you think about computer science today? Is it robust?

ABRAHAMS: Well, first, I have to admit I'm not really keeping up with it.

NORBERG: Well, let's make it 1990 or so.

ABRAHAMS: I would say it's a going enterprise. Certainly there's so many different aspects of it now. The whole advent of personal computing and the Internet and all of these kinds of things, the popularization of it has cast the whole business in a very, very different light. The fact that, all of a sudden, everybody knows about computers, makes this field look very different. And there's a popular participation in a way that's very unusual in scientific fields. Maybe there are other analogies, but I can't think of them.

NORBERG: I can't think of them, either.

ABRAHAMS: I guess that there's a certain amount of work that gets done because people get paid to do it. You know, I think in the computer field. People say, well, they can write a proposal; they can get a grant, and somebody will pay them. I think that relates an awful lot of what goes on, and some of it, I think, ultimately, will just not have very much significanceeither practically or theoretically. So in that sense I'm perhaps a bit of a skeptic, but there's also a lot that is useful, and sometimes, the things that people develop theoretically do turn out to be useful. Maybe I should mention one of the feelings I've been kind of skeptical of is program 
verification, and the whole idea that programs should be proven correct and treated as a formalism, which was Dijkstra's view. In fact, Dijkstra did not have much to do with real computers, and he was very proud of the fact that he did most of his writing with a pen.

NORBERG: Suppose I changed that sentence to say, how do you think computer science is coming to a robust science of experimental computing? Does that change your view any?

ABRAHAMS: I would say the experimental side of it, certainly it's happening; it will happen, because there's a lot of motivation for it. How will we improve the way we do this? How will we build better TV sets? It's the same sort of thing now. How do we build better automobiles? How do we build better anything? People are working on that, and there are so many different aspects of it. I think of scientific computing as one that I think of first, but that's hardly the only one.

You reminded me of another interesting subject I've been very interested in in a very amateurish way, which is computer security. Maybe this is even a bit of a motif in my career. There are times when I think, you know, a lot of the world seems to have an idea, and that idea just doesn't seem quite right. That accounts for my skepticism about program verification and my skepticism about software engineering, about a lot of the stuff that Dijkstra did, and also a lot of the things that people do in computer security. I've never really had the opportunity to sit down with somebody who knows the field and ask them about some of the things that may seem to be painfully obvious about it.

NORBERG: Such as?

ABRAHAMS: Such as, people tell you what you should not use as a password. I've never heard a computer security person come up with a strategy for how do you do passwords, given that every website you go to needs a password. Human memory is very imperfect. So do you have a different one for every website? People can't manage that. There are websites you go to once and you never go back to. You have different degrees of security. The one that you need for accessing the New York Times needs less security than the one that you use for accessing your bank account. Probably that's different from the one for email, and different from the one for eBay. And so you have all of these different ones. How does a human being with limited memory manage them?

NORBERG: Yes, you have to write them down.

ABRAHAMS: Yes, but they tell you you shouldn't do that. And so they never have come up with a positive answer. You have a ton of smart people. I wonder just, you know, how can they have this reality staring them in the face and pay no attention to it? I wonder about that.

NORBERG: But aren't there some cases where they do suggest that you not use this and you not use that and have four numbers and four letters and something like that?

ABRAHAMS: But how do you remember four numbers and four letters, especially when they're different from every website that you go to. If you do what they say you should do...

NORBERG: Yes, well I don't. 
ABRAHAMS: Yes, you and everybody else. They tell you what you shouldn't do, but they don't tell you what you should do, and to me, that's the reality that is so obvious, and they seem to be ignoring it. I just never see a recommendation of, here is how you should manage your passwords, and we can defend it even for people with limited memory, because we all have limited memories. It's just how limited is it?

Another thing that struck me-I can go on and on about this subject. That's one aspect of it, the fact that they don't tell you the positive advice. Another thing is the security precautions that create a great deal of extra effort but seem to be totally unjustified and totally unnecessary. I can understand, for example, why you get pushed to change your password. Again, there's a memory problem. If it's hard to remember, the password is even harder to remember than the password you just changed a week ago. We know that people can do brute force attacks on passwords, but the essence of doing a brute force attack is to be able to try a lot of things, and a lot of things, probably, in the millions, at least - at least. Furthermore, the technology is very simple and obvious for how you limit the rate at which things are tried, without even inconveniencing people. It really doesn't inconvenience me very much, if at all, to be told that if I mis-guess my password, I can't put another one in for five seconds. That's not much of a burden at all. I might not put another one in for five seconds anyway. And then you say, well, if you're limited to five seconds per attempt, how long will it take you to do a million attempts? The answer is, a very, very long time. Furthermore, suppose you had a rule that says that there's some kind of intervention after 5,000 false tries.

NORBERG: At my bank, the intervention's after three tries.

ABRAHAMS: Mine, too. Mine, too. And you really wonder, what are these people thinking? If you can't guess it in one try, you're not going to guess it in 200.

NORBERG: That's right. You're not.

ABRAHAMS: So where do you come up with this three? These aren't stupid people, but you wonder, what are they thinking? So in that sense, computer security seems like it's just in a very strange state. There are other issues that I've been very interested in, like, who am I in terms of proving? I say I'm Paul Abrahams. How can I prove it to you that I'm Paul Abrahams? Who is Paul Abrahams? I suppose the ultimate answer is, Paul Abrahams is a person with a certain DNA. I mean, that seems to be a kind of base identity. But there are two questions that come up about identity. Somebody can ask me, "Who are you?" and that's a very different question from, "Are you Paul Abrahams?" So verifying your identity is very different from somebody being able to ascertain your identity, which is where all the privacy issues come up. There are things that people have developed - you know, these zero-knowledge proofs and stuff like that - that seem to have the right technology to deal with this. But they don't seem to spread around. You know, it's probably almost a philosophical, political question, a technical question about how do you, on the one hand, verify the things you need to verify? When I sign into my bank account, I need to prove that I am who I say I am. On the other hand, how do you protect privacy?

NORBERG: How do you prove it? We use the number that's either on one of our cards, and we have a password. How do you prove that that's Paul Abrahams? It could be somebody else all together. 
ABRAHAMS: That's right. So in that sense, it's only because it's correlated with other things. When they set up the bank account, I provided that information. I don't remember what else I provided.

NORBERG: Mother's maiden name, probably.

ABRAHAMS: And of course, these things spread around. They keep trying to find new ones, and the new ones spread around also. Social security number is another example of that sort of thing. The attitude that banks seem to have: well, basically, we are the only ones who are asking you this question, when, in fact, 30 other banks are asking me the same question. So to me there's a very strong air of unreality about all of this, and yet I don't think ultimately the problem is unsolvable. I mean, suppose there were a dynamic DNA test or something like that, where basically you put your finger down on this thing and it proves that I have the DNA associated with Paul Abrahams. I mean, of course, there are these things of identity theft that go on, and they probably have to start at birth, because otherwise, identity could be stolen by somebody else.

NORBERG: Or there could be another Paul W. Abrahams that turns out to be relevant. You get mixed up. I remember there was a case at Berkeley where there were two Roger Hahns on the faculty, and occasionally, the bank got it wrong, and one guy got two checks, and the other guy didn't get any.

ABRAHAMS: I'm sure you have asked yourself the question, "How many Arthur Norbergs are there in the world?"

NORBERG: Yes, and I've tried to look them up in the sense of going through phone books when I'm in a particular town and look at it, and there's always one, rarely two in big cities. I don't look through the small towns, though.

ABRAHAMS: In computer science, I don't remember the first name, but there were two different Robinsons with the same name who were in closely related fields, and they were always getting mixed up. And then I think about the ACM's executive director, John White. There must be millions of John Whites.

NORBERG: There's one at the National Academy.

ABRAHAMS: You go to a large apartment building in a Hispanic neighborhood, and there must be ten Felipe Rodriguezes!

NORBERG: But now you're really talking about—I'm going to assert this—you're really talking about application areas and trying to succeed in generalizing things in those areas such that you can solve whatever the problems are, like security and privacy.

ABRAHAMS: Yes. 
NORBERG: Here, I don't know what your practice is these days for keeping up with the field, but do you think that one area of computer science is more accomplished? I don't want to say better, because that's a quality judgment, but more accomplished than another? Could you sort of list those for me, and why you think that's true?

ABRAHAMS: Well, I can think of one thing. I haven't been following it, but my impression is that the art of compiling and structuring, which used to be a very big issue, has pretty much gotten solved. People may still tweak it a little bit, but basically, people aren't making huge strides in building compilers anymore, because they've done it. That's the one that occurs to me, because it's an area I worked in. The rate of innovation of programming languages seems to have slowed down — not that new ones don't keep coming up, but they come up much less often.

NORBERG: Do they have the same generality that something like COBOL and FORTRAN have, the new ones?

ABRAHAMS: That's a good question. I mean, I think of something like Java. They seem to have different flavors, so I have a hard time comparing them. FORTRAN and COBOL were very different. Of course, people were trying to incorporate both of them. One of the things I should mention, which maybe we'll get back to if we have a little bit of time is, I did my own programming language design. I never got it published, but I actually pursued it fairly far.

NORBERG: Go ahead with the description.

ABRAHAMS: I called it SPLASH—Systems Programming Language for Software Hackers. The idea was, you know, if I considered myself a software hacker, what kind of language do I want? It's object-oriented, like most of these things are these days. I was quite eclectic in the sense of borrowing from a number of other languages, which I had no apology for at all. I borrowed things in some interesting and different ways, and I had a lot of experience, when I worked on this, in programming language definition, and at the same time, I had a sense of what actually makes programming easier. For example, data type conversions, that was a fairly complex problem. How do you handle them automatically and make them seem natural? I remember spending a lot of energy on that issue. Parallelism, how do you deal with that? There was a programming language I always really liked-ICON, which was developed by Ralph Griswold down in Arizona, and it had the notion of failure, which was not necessarily a bad thing, as a central concept. I thought it was really, really elegant, but nobody else did it. So I incorporated that as an essential element. I even thought a little bit about the implementation of it, the fact that when you execute certain computer instructions, if there's some extra information left over-I don't remember exactly how this worked anymore, but some kind of condition codes that you could retrieve. The idea of failure was that if you ask a certain questions, the answer is not-- let's see. How did this work? The best example may be, you search for one string within another, and if you find it, you locate where it is, and if you don't find it, you get failure. Well, failure doesn't mean anything's really wrong; it just means it isn't there. In the actual behavior of some computer machine language level instructions, it mirrored the semantics, and so you could take advantage of that in a compiler, and I thought about that for a long time, so I don't remember exactly what they were, but I thought it could be very useful. I hope you don't mind my kind of going in different directions. 
NORBERG: Not at all.

ABRAHAMS: One of the pervasive problems in computer security is buffer overflows, and you can kind of look: where did this come from historically? Well, it never turned out to actually be a problem, and so much of it had to do with the way that strings are represented in programming languages, and that goes back to $\mathrm{C}$, the $\mathrm{C}$ language. There are two ways, basically, you can represent the string. One of them is, you put a zero at the end. It says, "The string has now ended." The other is, you have an area of storage, and you put a count in front of it that says, "This string has 37 characters in it." In security terms, that's far more robust. Well, why wasn't it done that way? Well, $\mathrm{C}$ was originally implemented on a PDP-11, I guess it was, or a PDP something or other, and there was a classic loop in $\mathrm{C}$ language for moving a string from one place to another. It was a one-liner. And it turned out to have a direct implementation in two instructions on the PDP-11, and that was very seductive. That's what basically caused Thompson and Richie to do it that way-I'm sure it was. They said, "Oh, this is really elegant; this is really neat; let's do it that way." So this infected the whole language, and that infection carries over today in the problem of buffer overflows, which is one of the big problems in security. And you don't get those if you use the count method of storing strings instead of the terminator method of storing strings. It just doesn't happen. I can't remember exactly what led me to that thing.

NORBERG: We were talking about other areas that are robust—which are the good ones and which are the poor ones.

ABRAHAMS: Well, that's certainly one of them.

NORBERG: How about AI these days?

ABRAHAMS: AI, they haven't solved the big problems. That reminds me of something else I wrote, "The World Without Work," did you see this?

NORBERG: I didn't see it, no, but I have it on the list.

ABRAHAMS: That represented things I had thought about since I was in grad school, looking at artificial intelligence. I asked the question, basically, what would it be like to have a world without work, and why was it unlikely to happen, and was it a good thing or not. Can we get computers to do all the work? I first started looking at problems that just seemed far beyond current technology — certainly certain kinds of speech understanding. One of my favorite examples was the computerized taxi driver. You know, when you look at all the things that taxi drivers do. There were other examples, too, of difficult tasks that seem just far beyond current technology. I asked, first of all, "How would you ever do these things?" Then I said, "Well, let's assume you could do them." And then the next step was looking at how they would fit into society. What sort of social problems would you have when you started doing this? What things could not be solved by this, for example, religious conflicts? There are all kinds of conflicts that people have that enhanced computing has no way of solving.

Then the question of, well, would this be a good thing, and what would it be like? And one of the things I remember thinking about a lot is, to what extent do we respond to things because they're human. And an interesting example to me was how do we regard a work of art 
versus a fake? If you can't tell the difference, what is the difference? We feel there is. Then there's the whole issue of provenance, where things come from, how we're affected by it. Provenance is not related, necessarily, to the essence - what it is versus where it came from. And I started exploring those issues. I don't remember the details anymore of what I wrote, but those were the kinds that I was looking at. There are a few things I wrote that I'm really pleased about. That was one. The Dijkstra letter that never got published was another, and then probably it's even in some of the things I wrote much earlier. Even the things I wrote when I was at MIT, I think I wrote a couple of good things. I thought about the weak and strong progress theorem. I did that. That's something I was proud of. There have been a few others, but, you know, it's been a long time ago since I wrote them.

NORBERG: Did they get published when you were at MIT?

ABRAHAMS: Some did; some didn't. The Dijkstra letters, I mentioned, never did, and I still think that's a shame.

\section{Session 3, Tape 2, Side A [No Side B]}

ABRAHAMS: You know, I figure we probably have about an hour left, so I thought maybe you have things you want to ask, I'm sure.

NORBERG: I'm done now.

ABRAHAMS: Oh, okay, because there are a lot of things we never got to talk about - my more recent activities. I think, like a lot of people, one thing leads to another. There was a whole lot of work that I did for IBM. I mention that I did teaching there about PL/I. I worked on a manual for them, and then I subsequently got involved with the SEDL project with Jerry Fisher. That was Software Engineering Design Language, and again, that was the case of writing a manual for them. As I was working on that, I was also very involved in language design, which was always a subject that interested me, and the SPLASH language was an example of that. That led to another consulting project, which you probably never heard about, for a company called Prometheus, which was run by a man named Jim Byrnes, who is at, I guess, UMass Boston or something like that, a professor there in...I forget exactly what his specialty is; not statistics, but something similar. Anyway, he was running a consulting company, and his specialty was getting SBIR contracts - small business innovative research. He knew me, or he met me, through Carl Berry, who was one of my co-authors on the TeX book. He thought I might be able to develop some proposals for him. So I did get involved in just proposal writing, which again, was something I was reasonably good at, and then I developed one of my own, which was-I just retrieved it—a study called "Software and Reverse-Engineering Tools for Inclusion in Open Architecture Environments". Basically, it was looking at the question of, people talk about how to derive programs from specifications; let's turn that around and see, can we derive specifications from programs, and use that as a method of doing reverse engineering. And so it turned out that my work on SEDL, which was a software engineering design language, looked like it could be very relevant to that. So I developed a proposal and actually did a study of this, and like so many of the things, it sort of half-worked. Just looking at the report here, I don't 
know if there's anything that you can gain by looking at this document. You might just want to spend a minute to see if there is anything to be gained by it. That's the final report.

NORBERG: Would you say that this reverse engineering is analogous to somebody buying a piece of hardware and seeing how it was designed and worked and building your own or getting around the patent somehow?

ABRAHAMS: Well, it's very similar, except that in this case, it's not necessarily a hostile act. You know, we think of reverse engineering as basically a way of stealing ideas. In this case, the idea is you have an old program, and you want to rebuild it, and so this is a way of finding out what it does so you can rebuild it. And the idea of it was that SEDL was a kind of executable specification language, or almost executable, and so that seemed to be a natural way of expressing these specifications. So then the question was, what can you do to translate a program into SEDL, rather than translating SEDL into a program? And that's what I was looking at. There was no hope of doing it mechanically, but you could do it through some efficient editing processes, or so it seemed.

NORBERG: Who was involved in this beside you? I was looking for a list of names, but I haven't found any.

ABRAHAMS: I just did this myself. SEDL, of course, was a different story. That was developed by a number of different people at IBM. I suppose Jack Schwartz was the parent of it, but several generations back. That was Jerry Fischer primarily, and also Norman-- maybe there's even an acknowledgement somewhere, but Norman Cohen maybe. He was working with Jerry at Yorktown Heights, and I spent a lot of time with Jerry up there, too, working on this. I used to go to many meetings there.

NORBERG: Did they implement it in any way, IBM?

ABRAHAMS: Yes, they did. I don't know if it ever got out beyond IBM, but they did have a compiler for it. Very interesting for me to look at these things. They bring back memories. It's also interesting for me to look at things I wrote years and years ago, I'd say, "Did I write that?" because I kind of enjoy the things that I used to write, though I can't remember writing them.

NORBERG: That is, I'll say, self-explanatory, and the ability to expand on that is not there, but the context is, and that's what you've been describing.

ABRAHAMS: Yes. So that was something I was working on. Ultimately it got into a phase two, and that was a nice income source, and then it just basically didn't go anywhere after that. Jim was always interested in getting me to do more of these things, but I just never had any real ideas.

One other consulting thing I might mention was, for a company that went broke ultimately in Brooklyn called Health Information Systems. I did a fair amount of work for them. I guess that was probably in the mid-' $80 \mathrm{~s}$. They were producing, basically, computer systems for hospitals. It was a very interesting company in that it was composed almost entirely of Orthodox Jews. And a couple of them, they knew me because they had been graduate students at NYU. I'm sure you hear this all the time, these oddball connections in people's careers. I remember 
designing some kind of input/output system for them and doing some writing for them, and I forget what else I did, but it was both writing and programming that I was doing for them.

NORBERG: Why did they go under? Was it premature?

ABRAHAMS: Financial mismanagement, I believe. The people that were running it were just spending too much money on perks, as far as I can tell. Time Magazine or Business Week once listed it as a real up-and-coming company, but up-and-coming turned into down-and-going.

NORBERG: It strikes me that it was too early, because when I think about the systems that I've had contact with in the medical field - both hospitals and HMOs - that really didn't hit. Computerization really didn't hit until 2000, and then sometime after that for the patients to get access to it, as well.

ABRAHAMS: Well, I think as well as I can remember, they had a pretty good handle on things technically, and they did get into a couple of hospitals, I remember, but it was just that the company wasn't managed very well. It wasn't really a problem of not having the right products, as far as I can remember. I do remember just getting my last consulting payment from them was a challenge. They had very fancy offices. So that was kind of a nice, little gig.

On a completely different aspect, I guess I didn't mention that one time I was very involved in oboe playing, but that's a very difficult instrument to keep up because of the embouchure issues and the reed-making issues, while I was quite devoted to it. Thinking back on it, there's a little bit in common between deciding to learn oboe and deciding to build a PL/I compiler. The oboe is one of the more difficult instruments, and PL/I was a more difficult language to compile. Building a harpsichord was one of the more difficult woodworking projects to undertake, especially if you had never done woodworking and don't even have the right tools for it. So when I think about my career and my life, this may have been the motivation, that I kind of liked these kinds of challenges. There are things that a lot of other people are doing, but I picked the harder examples of it. I could have maybe learned an easier instrument than the oboe, or I could have compiled an easier language than PL/I.. So these kinds of languages as well as these kinds of challenges have always had an appeal for me. And even now, I do crossword puzzles. I do cryptic crossword puzzles, which are one of the hardest forms of crossword puzzles.

NORBERG: Has this kind of activity, I'll call it, slowed down somewhat? And would that indicate that the amount of consulting now is relatively low?

ABRAHAMS: It's practically zero, but I don't mind that. You see, I've reached the point where I feel I'm not living luxuriously by any means, but I'm managing economically, and so there's a great luxury in that, because I feel I can just have fun. I don't have to prove myself to the world; I don't have to do useful things. I can just have fun, and I kind of enjoy that stage of life. So I do things like play a lot of computer games. One of the games I happen to like is Spider Solitaire. There are different ways of playing Spider, and I probably chose one of the hardest ways of playing Spider.

NORBERG: Which is what, four decks? 
ABRAHAMS: I guess it's two decks, four suits. But that's not the end of it. Normally, the objective in Spider is to clear the table - to get a complete suit and get it off the table. But there's another set of rules, what the aim is, which is you don't clear a suit when it's complete; you have to leave it on the table, and the object of the game is to get all eight suits (because there are two decks) lined up.

NORBERG: I've never tried that.

ABRAHAMS: Well, it's very hard. It's almost impossible if you're just trying to do it in one pass straight through. So you make another change, which the program I'm working with allows, which is, you can back up. And all of a sudden, it becomes a real intellectual challenge, because on the one hand, you have the ability to back up, so you can look at, "Well, what should I have really done?" Some games are pretty easy with that, but some are devilishly difficult. I can spend five hours on a game of Spider, because I get stuck with it and go back - what could I have done differently? It becomes a very challenging game on that level.

NORBERG: Five hours is a long time for me to sit in front of the computer doing anything.

ABRAHAMS: I just get captivated by it. I don't get up. I don't go to the bathroom. It just grabs me. But then I've always had this obsessive-compulsive streak as so many different people in the sciences do. So there's that. There's the cryptic puzzles. There was something else that occurred to me that seemed to be in the same vein. There's another computer game I got involved with for a while that fascinated me, which is called Railroad Tycoon, where you basically build railroad networks. I always liked trains, anyway, like a lot of people. It doesn't just involve the construction of the railroads; but you schedule trains; you have to look at the finances of it, how do you finance the railroad company, when do you buy bonds to borrow bonds. There's a stock market involved, and many, many different aspects. It's a very, interesting game. There are also some defects in the design that endlessly frustrated me- things that should have been possible but weren't. There were problems in the implementation, occasionally, where you couldn't build a track from here to there, not because there was anything in the rules that you couldn't, but when you tried to, it somehow vanished. So that kind of problem.

NORBERG: Tell me, Paul, if you can, you spent, what, 40 years in computing, maybe a little longer?

ABRAHAMS: I started when I was 17 , and I'm now 72 , so that would be 55 years.

NORBERG: That's a long time. How do you evaluate the field over that 55 years in terms of its contributions to the intellectual life and its contributions to society in terms of the applications, and maybe to the individuals themselves? Could they have done something differently and done it better?

ABRAHAMS: Let's kind of go through that one by one. Computers have made life very, very different. When I think of what was my life as a ten-year old or even at MIT, all of the things that were very laborious, so many things are now very easy. I was just thinking, the boundaries between computer technology and other technologies are very blurry now. I was thinking about 
copying technology. In the old days, it used to be that making a copy of a piece of paper was a very big project. Now, if I want ten copies of something that I've just produced, it's easy-no problem at all. Communications, the kinds of-- maybe this is just a comment about technology in general, but computers are so intricately tied into what technology is that it's hard to really draw a boundary there. So computers have made life a lot easier, and also in some ways, a lot more complex. They've affected social interactions in the same way that the telephone did-you know, it used to be that people could not interact except by either being near each other or writing letters. It's very, very different now. So it's affected social structures. So that was one part. Let's go through the rest of the question.

NORBERG: Over the 55 years you have been in the computing field, how has it changed, and by that, I mean, how has it changed society? How has it changed individuals? And how did it change education? I didn't put that in before.

ABRAHAMS: Well, let's start with education. I haven't taught for a long time, but one of the transitions I've noticed is I don't think people write on the blackboard so much anymore. That was a big transition in and of itself, because so much of education came down to-- I guess someone once defined it as information passing from the notebook of the teacher to the notebook of the student without passing through the head of either. I remember a course in abstract algebra I took in MIT which basically consisted of the professor writing a book on the blackboard and the students copying it into their notebooks. I think there's probably much less of that sort thing now because it's become so pointless. Think about the humanities where people used to do, years ago, concordances as doctoral dissertations. Now its trivial to do a concordance. So computers have that effect. So they've certainly affected academia that way. Another example of how they affected academia, it used to be that the University of Chicago had very rigid rules about how theses were typed. They had to be typed, basically, by a certified typist, because the university didn't believe that anybody else could do it correctly.

NORBERG: I remember that.

ABRAHAMS: I don't know what they do now, but I can't believe they'll do that.

NORBERG: They'll take a disk now in Word.

ABRAHAMS: So that's an example of how one of the maybe slightly peripheral aspects has changed.

NORBERG: There are some good aspects, too. For example, just at the end of my career, which was 45 years long, this notion of using websites in class came in, and the university insisted that faculty members build one for each of the courses they were teaching. Well, I was about four years from retirement, and I thought, "What am I going to do that for?" I resisted until I became enamored with the technology.

ABRAHAMS: Great example.

NORBERG: And at that point, then, the course changed, because I wasn't standing up there lecturing about this machine and that machine, but it was the trends that was going on over the 
course of 200 years in the United States that became the focus of the course. So computing did that. I gave all the stuff to one of my colleagues. I don't know whether they're going to use it or not. Have the people in the computer field changed in the same way, that the underlying knowledge in technology, including software, forced them to do things differently?

ABRAHAMS: Well, things have become not only much more pragmatic, I think, but somehow the boundaries between what's academic and what's commercial have shifted.

NORBERG: That's true.

ABRAHAMS: I guess when you're doing a lot of computing, you kind of have to know what's going on in the commercial world, of what is being built. I think some of that may have always been there. For example, in the early days you needed to know IBM computers, and IBM computers were, of course, a commercial product. But I think that probably has intensified. Life has a different feel now, as well as professional life, but of course, we're really trying to focus on professional life at this point. Mechanics of things generally have gotten a lot easier, but the complexity of things has grown. In fact, you reminded me of another observation I have made, which was that back in the mid ' 50 s, it was possible for an individual, reasonably astute, to pretty much know everything that was going on in computing. No way now. The proliferation of the field, the spreading out into different domains, has been so extreme that you could only know a tiny corner of it now.

NORBERG: Just like any field once it's become mature.

ABRAHAMS: Some do this more quickly than others. Or it may be that it's a sign of the maturity of the field, when this starts happening. You can certainly see it in medicine. What psychologists know has virtually no overlap with what pathologists know, and even different kinds of surgeons know different kinds of things.

NORBERG: But the applications of the computer to the medical world in terms of keeping records, keeping interactions understandable, and so on, it seems to me that this has forced the doctors or physicians to change their view of how they treat the patient.

ABRAHAMS: Absolutely.

NORBERG: You have to involve the patient now, whereas when I was young, you didn't involve the patient. I can remember many surly remarks about, "Well, you just have to change your life to get rid of stress," and so on. That's nonsense.

ABRAHAMS: Well, I think that computing has probably suffered less from fruitless paths than medicine has. When I was in my early 20 s, I had an ulcer. So what was the remedy given to me by this doctor with many fancy plaques on his wall, fellow of gastroenterology? Bland diet.

NORBERG: And maybe some medication that really sent you out in the great beyond.

ABRAHAMS: I don't think I even had any medication. Basically, it was bland diet. That's what he was saying. I got over it. Haven't had one since. And of course, now it's understood 
that it's bacterial. I had my tonsils taken out as a four-year-old. They don't really do that anymore. Medicine has certainly changed, but computing doesn't have quite as many false tracks. Computing, I think, has moved a lot more linearly. There may be something that I'm just not thinking of. And people kind of lose interest in things - for example, certain kinds of optimizations that people devoted a lot of energy to in the early days that are simply irrelevant now. I think of back in my early days, programs were stored on magnetic drums, and how you optimized the access to the drums was a big issue. Who would ever think of such a thing now? There are still odd carryovers. In fact, I noticed them in the Unix world. One of the carryovers is referring to the thing you look at, the screen, as the console. That goes way back to the early mainframes. And when I look at Unix, there are lot of examples of this sort of thing. There are certain functions in the Unix library, such a function called stty, ("set teletype"). stty is, by itself, an anachronism, and yet that name is embedded in the most recent systems. There were all these things in the definition of sty about how to send codes to these various terminals that haven't been made for 20 years, and if you look at a Unix or Linux manual, even, I think you'll find that they're still in there. I haven't checked that recently, but it was not very long ago that that was the case. So there are all these anachronisms that kind of don't quite fade out because it's difficult in computing to get rid of things.

NORBERG: That strikes me as being a handicap.

ABRAHAMS: Oh, it is. It is, because you're carrying this extra burden on your back. How much of that is tradition and how much of that is actually necessary, I'm not sure at this point. I'm sorry if I'm kind of drifting, but you're asking some very interesting questions, and when I get off on one aspect, I forget what the question was.

NORBERG: When you say you don't spend a lot of time anymore in programming and you're really dealing with those things that have been applied, like the games, which is a really remarkable development in computing, I'm wondering-- I don't mean this to be pejorative, Paul, but I'm wondering how much of that is you've lost interest in those problems, and how much is it that they've passed you by, if they have?

ABRAHAMS: Well, I think some of it may just be a matter of energy. I still get to do little bits of programming now and then, and I enjoy them, and I'm pretty good at them. An example was- you know, I wouldn't even call it a consulting project. It was a few years ago. Somebody in town has a rare bookstore, and they needed to keep track of their collection, and they were trying to computerize that. They actually had a program for it, but the program was no longer being supported, so they needed to convert the data from that program to a different program. So I was asked to help with that. It was a little bit of a consulting gig, but it involved writing a program for the data conversion. In fact, I wrote the program in my favorite old language, ICON. And it was a lot of fun. I did it pretty well, and I enjoyed doing it. If I really had a reason to write a program now, I could write a program. 15 years ago, I had the ambition that I would, at this point, still be actively programming. It's probably a matter of energy rather than ability that I'm not, because if I have a reason where I need to, I still can. You know, I understand the concepts; I understand the methodology. The one thing that's a little bit more difficult now is, I sometimes might have difficulty maintaining the concentration, but then, when I think about what I do playing Spider, I probably do have the ability to maintain concentration; I just kind of have to 
look at it the right way. Clearly, with anybody you interview, they're a different person at 72 than they are at 52 .

NORBERG: Of course. Even I know that about myself.

ABRAHAMS: I consider myself lucky that I haven't decayed more than I have. Then again, another thing about my family is that they're pretty long-lived, and the people have pretty much kept their mental faculties practically until they died. Like my grandmother who died, I guess, at 97 or something like that, and she was really quite sharp right up until the end. I have an uncle who I guess is about 87 or 88 . He got reasonably wealthy, and basically his hobby is managing his money. He does very well at it. Anything you ask him about- the stock market or investments - he knows it. So I guess some of that is just genetics. I'm very lucky in that sort of thing.

NORBERG: Me, too.

ABRAHAMS: You're much more active than I am, even, at this point in your life.

NORBERG: Yes and no.

ABRAHAMS: Maybe you're active in different ways.

NORBERG: I don't do the games on the computer, but we have a five-year-old granddaughter living with us, and she takes a good amount of energy in trying to help her with her homework. She's now in kindergarten and so on. It keeps me focused. So there are these things that go on.

ABRAHAMS: And playing Go. I do that now. That's a pretty interesting example of something. I'm not sure what it's an example of. But you know, Go-how do you find people to play Go with? The answer is it's on the Internet, and if I want to play a game of Go, all I have to do is $\log$ in, and I play a game of Go.

NORBERG: And those are games that add to mental acuity.

ABRAHAMS: Yes, yes. Well mental acuity is very important to me. You know, even a certain amount of physical activity, I can't do quite what I used to do, but I still normally walk about 2.5 miles a day. Until not that long ago, I was jogging, but jogging killed my knees, so I gave up on that.

\section{END OF THE INTERVIEW}

